UNIVERSIDADE DE SÃO PAULO

FACULDADE DE ECONOMIA, ADMINISTRAÇÃO E CONTABILIDADE

DE RIBEIRÃO PRETO

DEPARTAMENTO DE CONTABILIDADE

ANÁLISE DAS VOLATILIDADES DOS MERCADOS BRASILEIROS DE RENDA FIXA

E RENDA VARIÁVEL NO PERÍODO 1986 -2006

NARA ROSSETTI

Orientador: Prof. Dr. Maurício Ribeiro do Valle

Ribeirão Preto

2007 
Reitora da Universidade de São Paulo:

Profa. Dra. Suely Vilela

Diretor da Faculdade de Economia, Administração e Contabilidade de Ribeirão Preto:

Prof. Dr. Rudinei Toneto Júnior

Chefe do Departamento de Contabilidade:

Profa. Dra. Maísa de Souza Ribeiro 
NARA ROSSETTI

\section{ANÁLISE DAS VOLATILIDADES DOS MERCADOS BRASILEIROS DE RENDA FIXA E RENDA VARIÁVEL NO PERÍODO 1986 -2006}

Dissertação apresentada ao Departamento de Contabilidade da Faculdade de Economia, Administração e Contabilidade de Ribeirão Preto da Universidade de São Paulo, como parte dos requisitos para obtenção do título de Mestre em Controladoria e Contabilidade.

Área de Concentração: Controladoria e Contabilidade Orientador: Prof. Dr. Maurício Ribeiro do Valle 


\section{Errata}

ROSSETTI, N. Análise das volatilidades dos mercados brasileiros de renda fixa e renda variável no período 1986-2006.2007. Dissertação de Mestrado. Faculdade de Economia, Administração e Contabilidade de Ribeirão Preto, Universidade de São Paulo, Ribeirão Preto, 2007.

$\begin{array}{lccc}\text { Folha } & \text { Linha } & \text { Onde se lê } & \text { Leia-se } \\ 92 & 11 & \text { negativa } & \text { positiva } \\ 92 & 12 & \text { diminuído } & \text { aumentado } \\ 93 & 01 & \text { aumentado } & \text { diminuído } \\ 93 & 04 & \text { positiva } & \text { negativa } \\ 93 & 05 & \text { negativa } & \text { positiva }\end{array}$




\section{FICHA CATALOGRÁFICA}

Rossetti, Nara.

Análise das volatilidades dos mercados brasileiros de renda fixa e renda variável no período 1986 -2006.

Ribeirão Preto, 2007.

$121 \mathrm{p}$ : il. ; $30 \mathrm{~cm}$

Dissertação de Mestrado apresentada à Faculdade de Economia, Administração e Contabilidade de Ribeirão Preto/USP Área de Concentração: Controladoria e Contabilidade.

Orientador: Prof. Dr. Maurício Ribeiro do Valle

1.Volatilidade. 2. Renda Fixa. 3. Renda Variável. 4. Séries Temporais. 


\section{FOLHA DE APROVAÇÃO}

Nara Rossetti

Análise das volatilidades dos mercados brasileiros de renda fixa e renda variável no período 1986-2006.

Dissertação apresentada ao Departamento de Contabilidade da Faculdade de Economia, Administração e Contabilidade de Ribeirão Preto da Universidade de São Paulo, como parte dos requisitos para obtenção do título de Mestre em Controladoria e Contabilidade.

Área de Concentração: Controladoria e Contabilidade

Aprovada em:

Banca Examinadora

Prof. Dr. Maurício Ribeiro do Valle

Instituição FEA-RP/USP

Assinatura:

Prof. Dr.

Instituição:

Assinatura:

Prof. Dr.

Instituição: Assinatura: 


\section{DEDICATÓRIA}

Ao Jorge, por todo amor, paciência e incentivo.

Aos meus sobrinhos, Lucas e Vítor, pela inspiração! 


\section{AGRADECIMENTOS}

Agradeço primeiramente a Deus e aos meus pais, pela confiança, torcida e dedicação de toda uma vida. Ao meu irmão Franco que compartilha comigo a experiência da vida acadêmica, à minha cunhada Kátia, pelas correções de português e às demais "dicas" e aos seus filhos, os pequenos Lucas e Vitor, pelas horas de descontração, essenciais para o desenvolvimento do trabalho. A Luciana, minha irmã, pelo companheirismo.

Ao meu orientador, Prof. Dr. Maurício Ribeiro do Valle, por acreditar que aquele projeto confeccionado no início do mestrado poderia vir a se tornar o trabalho aqui apresentado e, também, por toda a parceria ao longo destes dois anos.

Aos professores do mestrado em Controladoria e Contabilidade da FEARP: Prof ${ }^{\mathrm{a}}$. $\operatorname{Dr}^{\mathrm{a}}$. Rosana Grillo, Profa. Drª Maísa Ribeiro, Prof. Dr. Alexandre Assaf Neto, Prof. Dr. Roberto Vatan, Prof ${ }^{\mathrm{a}}$. Dr ${ }^{\mathrm{a}}$. Adriana Procópio, Prof. Dr. Evandro Saidel, Prof. Dr. Marcelo Nagano e Prof. Dr. Sílvio Nakao, pelos ensinamentos e conhecimentos oferecidos e, em especial, ao Prof. Dr. Milton Barossi Filho, pelas horas despendidas na compreensão da análise estatística.

À Professora Assistente (logo Professora Doutora) Mariana Simões Ferraz do Amaral Fregonezi, pela amizade de quase vinte anos e influência na escolha do curso de mestrado.

Aos meus colegas de mestrado, que compartilharam comigo esta jornada, em especial aos colegas Flávio Leonel de Carvalho por me ajudar na busca da bibliografia e nas formatações, ao colega Andrei Albuquerque pelo auxílio nos testes e à Kelly Farias, pela parceria nas disciplinas o que me permitiu maior aprendizado na área.

Aos colegas professores da Faculdade São Luís de Jaboticabal e Fundação Educacional de Ituverava por compartilharem minhas expectativas, e aos amigos de tantos anos que foram meu 
principal apoio durante todo o processo, compreendendo minha ausência nos encontros de fim de semana.

E essencialmente agradeço ao futuro Doutor, Professor Assistente Jorge Luis Faria Meirelles, responsável pelo meu ingresso na vida acadêmica, pelo imenso companheirismo e amor dedicados ao longo desses anos. 


\section{RESUMO}

ROSSETTI, N. Análise das volatilidades dos mercados brasileiros de renda fixa e renda variável no período 1986-2006.2007. Dissertação de Mestrado. Faculdade de Economia, Administração e Contabilidade de Ribeirão Preto, Universidade de São Paulo, Ribeirão Preto, 2007.

O presente trabalho tem como objetivo analisar a volatilidade dos mercados de renda fixa e renda variável no Brasil, no período de março de 1986 até fevereiro de 2006, por meio do CDI (Certificado de Depósito Interfinanceiro) e IRF-M (Índice de Renda Fixa de Mercado), como indicadores do mercado de renda fixa, e o IBOVESPA (Índice da BOVESPA), como indicador de renda variável. Por meio da comparação da volatilidade destes ativos é possível observar se há coincidência temporal entre os dois mercados, em relação aos picos de volatilidade devido, principalmente, a influência de variáveis macroeconômicas. Tal análise é importante para que os gestores de portfólios, que tomam decisões de como alocar os investimentos, conheçam o histórico e o corrente relacionamento entre as volatilidades dos dois mercados. As volatilidades do mercado de renda fixa e do mercado de renda variável foram calculadas por meio do desvio padrão anual dos retornos mensais e por meio de um modelo $\operatorname{GARCH}(1,1)$. Os resultados mostram que, no Brasil, durante o período analisado, os dois mercados apresentaram: períodos coincidentes de picos de volatilidade, grande mudança no padrão comportamental das volatilidades após a implantação do Plano Real e pouca estabilidade na relação entre as volatilidades.

Palavras-Chave: Volatilidade. Renda Fixa. Renda Variável. Séries Temporais. 


\begin{abstract}
ROSSETTI, N. Study of the volatility of the fixed income market and the stock market in Brazil in a period of 1986-2006.2007. Master's dissertation. Faculdade de Economia, Administração e Contabilidade de Ribeirão Preto, Universidade de São Paulo, Ribeirão Preto, 2007.

This work aims to study the volatility of the fixed income market and the stock market in Brazil, from March 1986 to February 2006, through CDI (Interbank Interest Rate), IRF-M (Fixed Income Index), as a fixed income market indicators, and IBOVESPA (BOVESPA index), as a stock market indicator. Through the comparison of the volatility of these assets it is possible to observe if there is time frame coincidence between the two markets, in relation to the peaks of volatility due to, mainly the influence of macroeconomics variables. Such analysis is important so that portfolio managers, responsible for decisions such investments allocation, know the history and the actual relationship between the markets volatility. Such analysis is important so that portfolio managers, responsible for decisions such investments allocation, know the history and the actual relationship between the markets volatility. Those fixed income market and stock markets volatilities were calculated through the annual standard deviation of the monthly returns and from a GARCH $(1,1)$ model. The results show that, in Brazil, during the studied period, both markets presents: coincident volatility peaks periods, high change in the behavioral pattern of volatility after the deployment of the Plano Real and little stability in the relationship between the volatility.
\end{abstract}

KEY WORDS: Volatility, Fixed Income, Stock Market, Time Series. 


\section{LISTA DE FIGURAS}

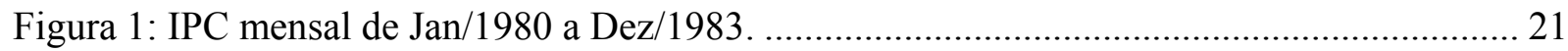

Figura 2: IPC mensal de Jan/1986 a Dez/1987. .................................................................... 24

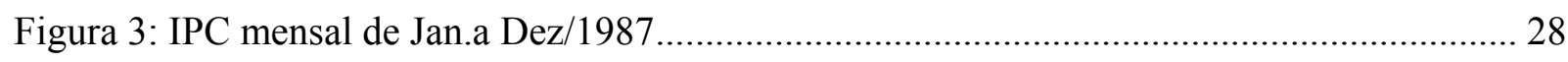

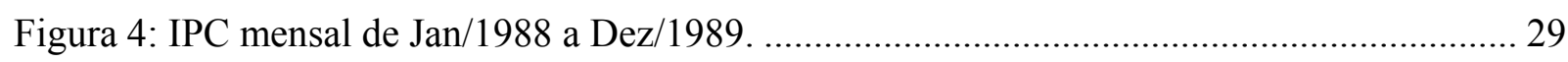

Figura 5: Taxas Reais de Juros (março/1986 a fevereiro/2006) ................................................. 31

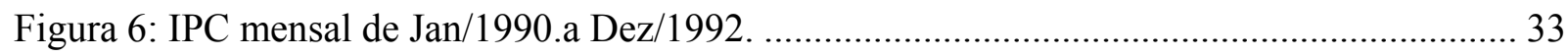

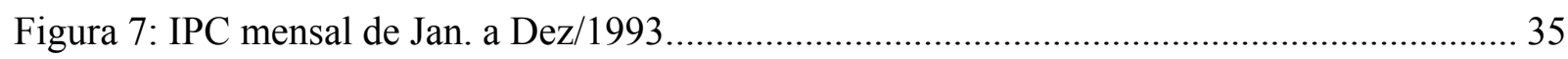

Figura 8: IPC mensal de Jan. a Dez/1994 _............................................................................ 37

Figura 9: Taxa de câmbio comercial para venda: real (R\$) / dólar americano (US\$) - fim período

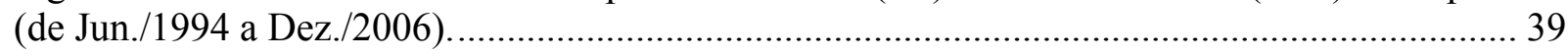

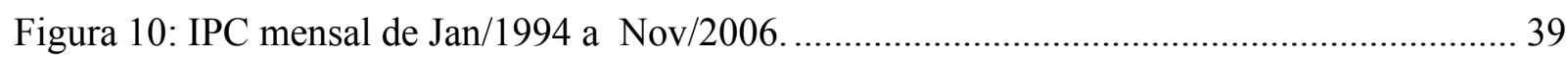

Figura 11: Variação Real do Produto Interno Bruto (de 1986 a 2006) .......................................... 40

Figura 12: (a) Volatilidade do Índice S\&P500 de 1990 a 2000 calculada por Reilly, Wright e Chan (2000), (b) Volatilidade do Índice S\&P500 de 1990 a 2000 calculada pela autora..............67

Figura 13: Desvio Padrão Anual dos Retornos Mensais - CDI de dez./86 a fev./06. .................. 71

Figura 14: Desvio Padrão Anual dos Retornos Mensais - CDI de junho/1995 a fevereiro/2006. 73

Figura 15: Desvio Padrão Anual dos Retornos Mensais - IBOVESPA - dez./06 a fev./06........ 75

Figura 16: Desvio Padrão Anual dos Retornos Mensais -CDI e IBOVESPA - dez./86 a

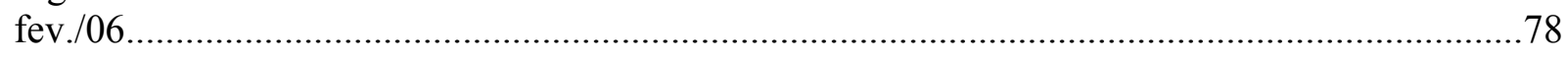

Figura 17: Razão do Desvio Padrão Anual dos Retornos Mensais -CDI e IBOVESPA - dez./06 a

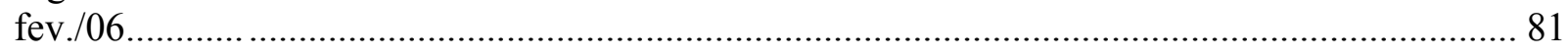

Figura 18: (a)Coeficiente Beta CDI $=\mathrm{f}($ IBOVESPA $)$ - dez./86 a fev./06 e (b) Coeficiente Beta

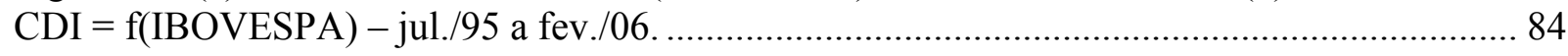

Figura 19: (a) Correlação CDI e IBOVESPA - dez./86 a fev./06 e(b) Correlação CDI e

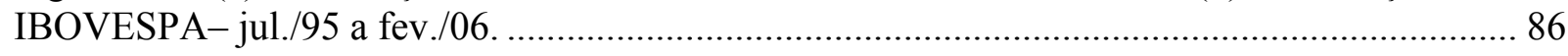

Figura 20: Desvio Padrão Anual dos Retornos Mensais -IRFM e CDI- dez./01 a fev./06......... 88 
Figura 21: Retornos Mensais -IRFM e CDI - dez./01 a fev./06. 90

Figura 22: Desvio Padrão Anual dos Retornos Mensais -IRFM, CDI e IBOVESPA - dez./01 a fev./06. 91

Figura 23: Razão do Desvio Padrão dos Retornos Mensais -IRFM e IBOVESPA - dez./01 a fev./06. 92

Figura 24: (a) Movimentações do Beta, (b) da Correlação dos retornos (c) e da covariância entre o IRF-M e o IBOVESPA. De dez./01 a fev./06. 94

Figura 25: Retornos Mensais do CDI Real(de mar./86 a fev./2006). 97

Figura 26: (a)Volatilidades GARCH(1,1) e Desvio Padrão CDI Real (de março de 1986 a fevereiro de 2006), (b) Volatilidades GARCH(1,1) e Desvio Padrão CDI Real (de julho de 1994 a fevereiro de 2006). 101

Figura 27: (a)Volatilidade GARCH(1,1) CDI Real (de março de 1986 a fevereiro de 2006) e (b) IBOVESPA. 102

Figura 28: Volatilidades GARCH(1,1) e Desvio Padrão IBOVESPA (de março de 1986 a fevereiro de 2006). 103

Figura 29: Volatilidades GARCH e Desvio Padrão IBOVESPA (de março de 1986 a fevereiro de 2006). 106

Figura 30: Volatilidades Desvio Padrão e GARCH(1,1)-IRF-M (dez./01 a dez./06). 111

Figura 31: Volatilidades Desvio Padrão e GARCH(1,1) - IBOVESPA (dez./01 a dez./06) 111 


\section{LISTA DE TABELAS}

Tabela 1: Resumo dos Índices Estatístico para Mercados de Bonds e Ações: Desvio Padrão

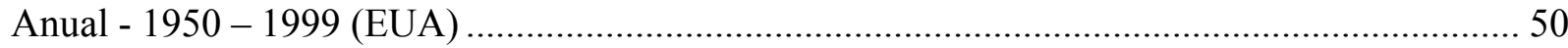

Tabela 2: Relação dos Desvios padrão - Mercado de Bonds Mercado de Ações (EUA)............. 51

Tabela 3: Resumo Estatístico Para os Mercados de Renda Fixa e Variável -Maiores e Menores

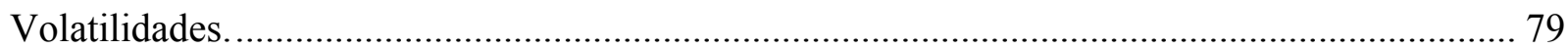

Tabela 4: Resumo Estatístico Para a Razão dos Mercados de Renda Fixa e Variável -Maiores e

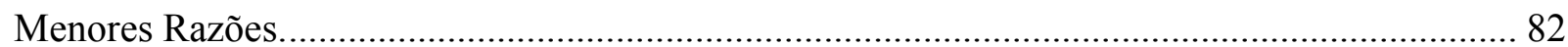

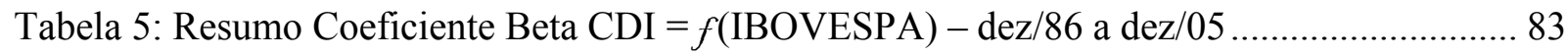

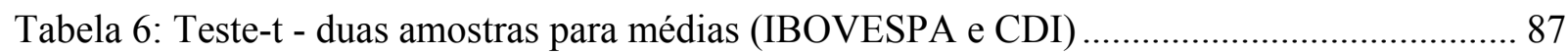

Tabela 7: Resumo Estatístico dos Desvios padrão Anuais IRF-M e IBOVESPA, da Razão dos Desvios padrão Anuais IRF-M/IBOVESPA e Coeficiente Beta IRF-M= $f($ IBOVESPA) - dez./01 a fev./06. 91

Tabela 8: (a) Teste-t - duas amostras para médias (IBOVESPA e IRF-M) e (b): Teste-t - duas

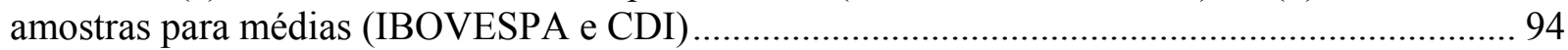

Tabela 9: Teste-t - duas amostras para médias (IRF-M e CDI) ................................................ 96

Tabela 10: Teste de Raiz Unitária - ADF - CDI Real ............................................................... 98

Tabela 11: Coeficientes da Equação do Modelo GARCH(1,1) - CDI Real ................................. 99

Tabela 12: Teste dos Resíduos ARCH- LM - CDI Real........................................................... 100

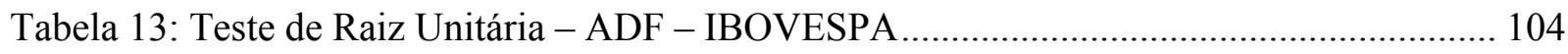

Tabela 14: Coeficientes da Equação do Modelo GARCH(1,1) - IBOVESPA ............................ 105

Tabela 15: Teste de Resíduos - ARCH-LM - IBOVESPA ….................................................. 105

Tabela 16(a) e (b): Teste de Raiz Unitária - ADF - IRF-M e IBOVESPA, respectivamente.... 107

Tabela 17: (a) Coeficientes estimados das equações de um modelo GARCH(1,1) - séries de

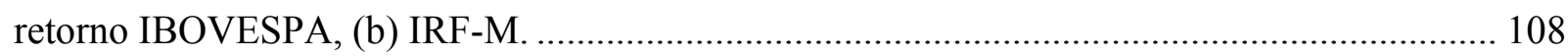

Tabela 18: Teste de Resíduos ARCH-LM - IBOVESPA e IRF$\mathrm{M}$ 


\section{SUMÁRIO}

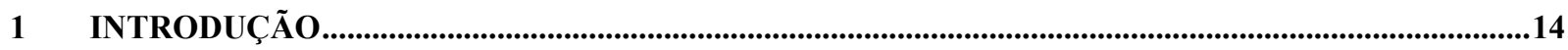

1.1 Problema de Pesquisa, Objetivo e Hipóteses............................................................. 16

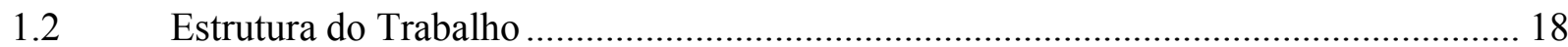

2 REVISÃO BIBLIOGRÁFICA................................................................................................................19

2.1 Panorama da Economia Brasileira no Período 1986-2006 …....................................... 19

2.1.1 Governo Sarney - Do Plano Cruzado ao Plano Verão ........................................... 20

2.1.2 Governo Collor - Planos Collor I e II ................................................................. 32

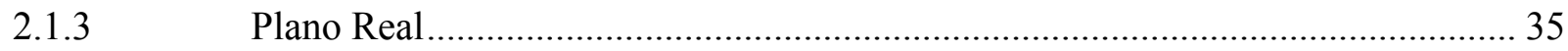

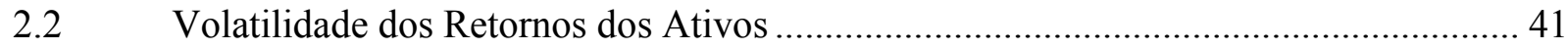

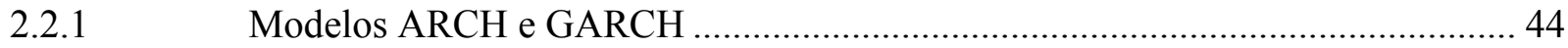

2.2.2 Testes Dickey Fuller (DF) e Dickey Fuller Aumentado (ADF) .......................... 45

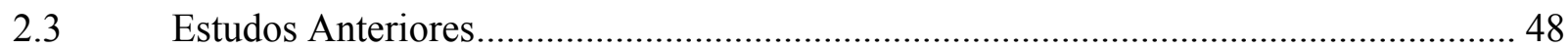

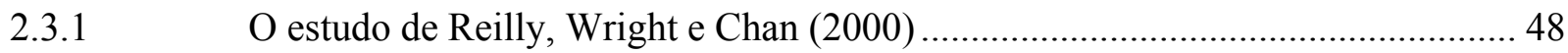

2.3.2 Os estudos de Young e Johnson na Europa $(2002,2004$ e 2005) ......................... 53

2.3.3 Estudos sobre a volatilidade do mercado de bonds ............................................. 55

2.3.4 Estudos sobre a volatilidade do mercado de ações............................................... 57

$3 \quad$ METODOLOGIA DA PESQUISA ……………….....................................................................................61

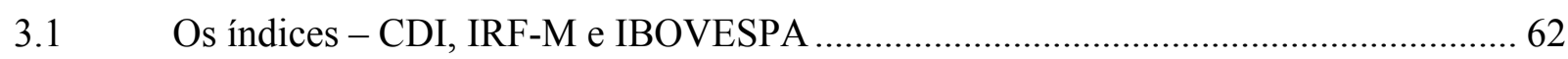

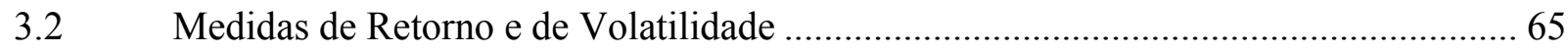

3.3 Volatilidade do mercado de renda variável versus volatilidade do mercado de renda fixa...... 67

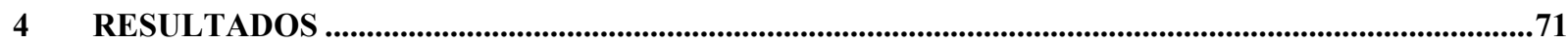

4.1 Volatilidade do Mercado de Renda Fixa - CDI ...................................................... 71

4.2 Volatilidade do Mercado de Renda Variável - IBOVESPA ......................................... 74 
4.3 Comparação das Volatilidades dos Mercados de Renda Variável e Renda Fixa .......... 77

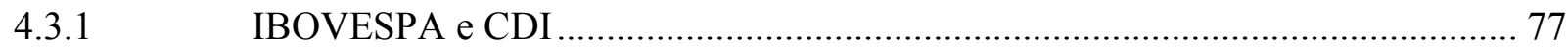

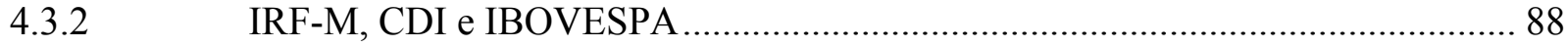

4.4 Volatilidade dos Mercados - Modelo GARCH(1,1)................................................. 97

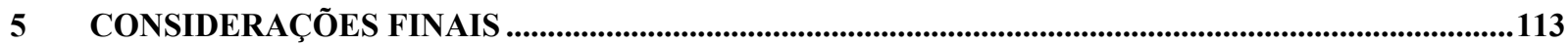

REFERÊNCIAS BIBLIOGRÁFICAS ...................................................................................................118 


\section{INTRODUÇÃO}

Durante a década de oitenta e início dos anos noventa o principal objetivo do governo para acelerar o crescimento econômico era conter a aceleração inflacionária. Diversos planos e pacotes econômicos foram lançados no período mencionado a fim de conter o avanço da inflação, sendo que o único a obter sucesso foi o Plano Real, implantado em meados de 1994.

Os diferentes regimes macroeconômicos provocavam a oscilação de variáveis como taxa de câmbio, taxa de juros e índices de inflação, o que tornava o preço dos ativos do mercado financeiro mais volátil. O cenário econômico dos anos oitenta e início de noventa promovia incertezas quanto à tomada de decisão dos investidores e suas aplicações financeiras, pois havia a dificuldade em se prever como os preços de determinados ativos se comportariam no futuro, o que elevava a imprecisão em relação ao retorno, principalmente dos ativos de prazos mais longos.

No mercado brasileiro de renda fixa, por exemplo, os altos índices de inflação e conseqüentes taxas de juros do Brasil tornavam pouco atraentes os títulos pré-fixados de prazos mais longos, devido ao maior risco que esses títulos estavam sujeitos. Os investidores buscavam, no mercado de renda fixa, liquidez imediata e o máximo de proteção possível às suas carteiras. Dessa forma, o CDI over (Certificado de Depósito Interfinanceiro de um dia), também por ser pós-fixado, acabou por ser eleito o benchmark desse mercado. De acordo com a BM\&F (2006) “o CDI passou a desempenhar a função de uma quase moeda para grande parte dos agentes econômicos".

Na segunda metade dos anos oitenta, em virtude da expansão monetária, as taxas de juros reais negativas provocaram fuga dos ativos financeiros para a Bolsa de Valores, dólar paralelo e 
outros ativos reais que apresentaram grande valorização no período (GREMAUD; VASCONCELLOS; TONETO JR., 2004).

Em 1990, no mercado de renda variável, ocorreram seguidamente o maior e o menor retorno mensal do período 1986-2006. Em março de 1990, o IBOVESPA registrou uma variação mensal negativa de cerca de $60 \%$ e, em abril, essa mesma variação ultrapassou positivamente os 100\%. Esse foi, portanto, o maior pico de volatilidade do período 1986-2006. Também em março de 1990 ocorreu a maior taxa de inflação desse período.

Somente o Plano Real, implantado definitivamente em 1994, obteve sucesso em relação ao controle da inflação. Com essa variável controlada, tornou-se possível uma melhor previsão do comportamento dos preços dos ativos, de seus retornos e, conseqüentemente, de suas volatilidades. Após 1994, ocorreu o restabelecimento gradativo dos mercados de títulos préfixados e dos derivativos de taxas de juros de prazos mais longos, títulos esses que estavam "fora" do mercado antes da estabilização da economia.

A tomada de decisões de como alocar recursos dentre diferentes ativos esbarra na necessidade de se conhecer o histórico e o corrente relacionamento entre as volatilidades dos mercados. Assim, este estudo analisa a volatilidade do mercado de renda fixa em comparação ao mercado de renda variável de 1986 a 2006, considerando, no período, os diferentes momentos econômicos pelo qual passou o Brasil, tomando como indicadores do mercado de renda fixa o CDI e o IRF-M e, do mercado de renda variável, o IBOVESPA.

Para tal análise, este trabalho procura reproduzir para o mercado brasileiro o estudo dos autores, Reilly, Wright e Chan (2000) que verificaram a volatilidade dos mercados de renda fixa e variável nos EUA e de Young e Johnson $(2002,2004,2005)$ que replicaram a pesquisa dos autores americanos, em países europeus: Reino Unido, Suíça e Alemanha. 
Espera-se, dessa forma, que este estudo contribua para melhorar a compreensão da volatilidade do mercado brasileiro de renda fixa e de renda variável, bem como auxiliar analistas e gestores do mercado de bonds e ações no gerenciamento de seus portfólios.

\subsection{Problema de Pesquisa, Objetivo e Hipóteses}

Devido às crises e variações da política econômica brasileira, e ao impacto que essas variações podem causar na volatilidade dos ativos financeiros, este estudo tem como problema de pesquisa a seguinte pergunta:

Como se comportou a volatilidade dos mercados brasileiros de renda fixa e renda variável, de 1986 até 2006, considerando os diversos planos econômicos implantados no país neste período?

Dessa forma, este trabalho tem como objetivo geral realizar uma análise comparativa entre as volatilidades do mercado de renda fixa e do mercado de renda variável, no Brasil, de 1986 até 2006, considerando os diferentes planos econômicos implantados no período.

Os objetivos específicos são:

* Verificar se há coincidência temporal entre os picos de volatilidade ocorridos nos mercados de renda fixa e variável;

* Verificar se há mudança considerável no padrão de volatilidade dos dois mercados após a implantação do Plano Real;

Verificar se existe uma relação estável entre as volatilidades dos dois mercados ao longo do tempo.

Dos objetivos específicos derivam três hipóteses a serem testadas neste trabalho. 
A primeira hipótese está relacionada à coincidência temporal entre os picos de volatilidade dos mercados de renda fixa e variável.

\section{* Hipótese 1:}

$\mathbf{H}_{\mathbf{0}}$ : As duas séries de retornos (renda fixa e renda variável) no mercado brasileiro não possuem picos de volatilidade coincidentes ao longo do período de tempo estudado.

$\mathbf{H}_{1}$ : As duas séries de retornos (renda fixa e renda variável) no mercado brasileiro possuem picos de volatilidade coincidentes ao longo do período de tempo estudado.

Nos estudos realizados por Reilly, Wright e Chan (2000) nos EUA e por Young e Johnson (2002, 2004, 2005), em países europeus, os picos de volatilidade dos dois mercados não foram coincidentes.

A segunda hipótese deste trabalho refere-se à mudança da volatilidade dos mercados de renda fixa e renda variável após a estabilização monetária conseqüente da implantação do Plano Real.

Hipótese 2:

$\mathbf{H}_{\mathbf{0}}$ : Não houve mudança considerável no padrão de volatilidade das duas classes de ativos após a implantação do Plano Real, em 1994.

$\mathbf{H}_{1}$ : Houve mudança considerável no padrão de volatilidade das duas classes de ativos após a implantação do Plano Real, em 1994.

A terceira hipótese a ser testada diz respeito ao padrão de relacionamento da volatilidade dos dois mercados, ou seja, se a relação entre as volatilidades dos dois mercados é estável ao longo do tempo.

\section{* Hipótese 3:}

$\mathbf{H}_{0}$ : A relação entre as volatilidades das duas classes de ativos ao longo de todo o período estudado não é estável. 
$\mathbf{H}_{1}$ : A relação entre as volatilidades das duas classes de ativos ao longo de todo o período estudado é estável.

Nos estudos de Reilly, Wright e Chan (2000) e Young e Johnson (2002, 2004, 2005), as duas classes de ativos não apresentaram uma relação estável ao longo do período analisado pelos autores.

\subsection{Estrutura do Trabalho}

Este trabalho está estruturado em cinco capítulos. O presente capítulo apresenta a introdução, O Capítulo 2 apresenta a revisão bibliográfica, que aborda o panorama da economia brasileira, o conceito de volatilidade dos ativos e os estudos anteriores e semelhantes a esta pesquisa. O Capítulo 3, Metodologia de Pesquisa, descreve o plano de pesquisa, as variáveis empregadas no estudo, a coleta de dados e a metodologia utilizada para a realização dos testes. O Capítulo 4, Resultados, descreve e analisa os resultados dos cálculos e testes estatísticos realizados. Por fim, o Capítulo 5 apresenta as Considerações Finais do trabalho. 


\section{REVISÃO BIBLIOGRÁFICA}

\subsection{Panorama da Economia Brasileira no Período 1986-2006}

A partir da segunda metade da década de oitenta e início de noventa, o Brasil viveu uma seqüência de planos econômicos, como Plano Cruzado, Plano Bresser, Plano Verão, Planos Collor I e II e Plano Real. Todos esses planos econômicos tinham como objetivo o combate à inflação.

De 1986 até meados de 1994, ocorreram picos de inflação que atingiram oitenta pontos percentuais, como em março de 1990, no início do governo Collor, em que o IPC (Índice de Preços ao Consumidor - FIPE) apresentou variação mensal de 82,18\%. Em junho de 1994, mês anterior à implantação definitiva do Plano Real, a taxa de inflação atingiu um pico de quase 50\%, para nos meses de agosto e setembro do mesmo ano, variar em torno de $1 \%$.

De acordo com Bresser Pereira (2003), em 1994 houve uma mudança brusca e favorável no sistema macroeconômico brasileiro: o Plano Real controlou a alta inflação que impedia o desenvolvimento do país desde 1980. No entanto, o próprio plano desencadeou a desestabilização do balanço de pagamentos com a valorização da moeda, e a taxa básica de juros da economia foi mantida em altos níveis.

Todos esses planos econômicos geraram grandes impactos no mercado financeiro e de capitais, já que os mesmos alteravam de forma significativa o preço dos ativos, a taxa de juros e a taxa de câmbio. Como o presente estudo visa analisar a volatilidade do mercado de renda fixa e renda variável para os últimos vinte anos no mercado brasileiro, buscou-se contextualizar o ambiente macroeconômico do período, para melhor compreensão dos resultados. 


\subsubsection{Governo Sarney - Do Plano Cruzado ao Plano Verão}

Nos primeiros anos da década de oitenta, o Brasil apresentava inflação elevada, mesmo com a persistência do quadro recessivo, segundo Gremaud, Vasconcellos e Toneto Jr. (2004).

Desde 1964, o país estava sob controle do governo militar, que teve fim em janeiro de 1985, com a eleição indireta do Presidente Tancredo Neves. Devido à morte de Tancredo, antes de sua posse, seu vice, o Presidente José Sarney, assumiu a Presidência da República e permaneceu no cargo até 1990.

A dívida externa elevada, as altas taxas de inflação e a crise do estado desencadearam no Brasil, nos primeiros anos da década de oitenta, uma crise nacional (FERANDES e PAIS, 2006), embora esse também tenha sido o período, segundo Gremaud, Vasconcellos e Toneto Jr. (2004), em que a recessão de 1981-1983 contribuiu para melhorar o balanço de pagamentos, revertendo o déficit existente na balança comercial em expressivos superávits, mas ainda assim, o efeito não foi sentido pela inflação.

Como observado na Figura 1, baseada nos dados do Índice de Preços ao Consumidor da Fundação e Instituto de Pesquisa Econômica (FIPE), nos quatro primeiros anos da década de oitenta, a inflação permaneceu alta, atingindo seu ápice no mês de julho de 1983, com variação mensal de $12,83 \%$, continuada pelo índice de junho do mesmo ano, apresentando um percentual de 11,77 e terminando o período com um IPC de 8,41\%. 


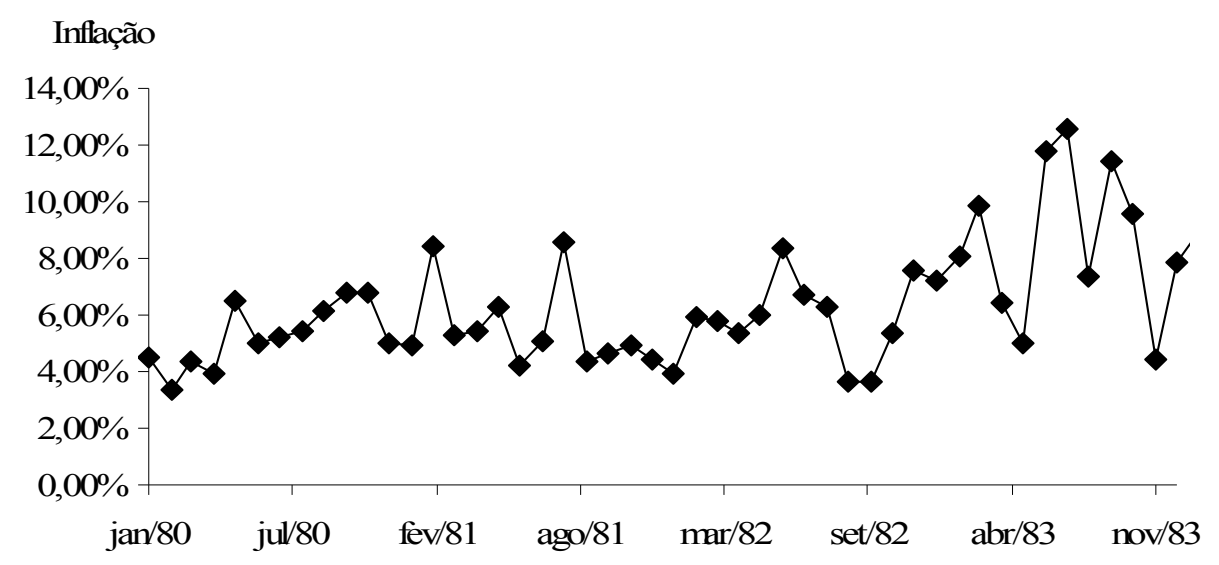

Figura 1: IPC mensal de Jan/1980 a Dez/1983.

Fonte: Elaborado pela autora a partir de dados da FIPE.

Segundo dados do Instituto Brasileiro de Geografia e Estatística (IBGE), o Produto Interno Bruto Real, que apresentou variação de 9,3\% em 1980, partiu para uma recessão e, em 1981 e 1983, apresentou variações negativas de 4,3\% e 2,9\%, respectivamente. Em 1982, o crescimento econômico ficou em torno de $0,8 \%$,

Segundo Ometto et al (1995, p. 404), o PIB per capita, que de 1970 a 1980 vinha se expandindo à taxa média de 6,1\% a.a., diminuiu 13\% entre 1980 e 1983.

De acordo com Gremaud, Vasconcellos e Toneto Jr. (2004), esta estagnação na economia foi decorrência de um processo de endividamento externo feito em décadas anteriores, que começou a ser cobrado, e de uma brusca elevação nas taxas de juros internacionais, já que os empréstimos tomados pelo Brasil haviam sido realizados na base de taxas de juros flutuantes.

Para Calderon e Fontes (1998), não foi apenas o aumento das taxas externas de juros que prejudicou o país no início da década de 80 , mas também uma maior queda no preço das commodities no mercado internacional em relação aos produtos manufaturados e o aumento no preço do petróleo, produto indispensável à estrutura produtiva brasileira. Além do que, em agosto 
de 1982, o México anunciou que não conseguiria honrar suas dívidas de acordo com seu cronograma.

Em 1984, o país volta a crescer e apresenta uma taxa de crescimento de 5,4\% (IBGE), o que se deve à expansão das exportações, tanto em função da recuperação da economia mundial como da resposta do setor exportador aos incentivos e à desvalorização cambial do ano anterior. Averbug (2005, p. 215) afirma que no ano de 1984 houve aumento do emprego, dos investimentos e melhora da produção agropecuária, o que acabou por propiciar condições para no ano seguinte "a demanda interna passar a epicentro da expansão econômica".

Como a primeira metade da década de oitenta apresentava volta do crescimento econômico e expansão das exportações, o obstáculo do bem estar econômico então era, sem dúvida, a alta inflação. Assim, o combate à inflação passou a ser o alvo do governo que sucedeu ao governo militar, na segunda metade da década.

Em janeiro de 1985 acontecem as eleições presidenciais indiretas que elegem, como Presidente da República, Tancredo Neves. Após sua morte, três meses depois da eleição, seu vice José Sarney assumiu o cargo, dando início a um governo de cinco anos e três planos econômicos que tinham como objetivo controlar a inflação: Plano Cruzado (1986), Plano Bresser (1987) e Plano Verão (1989).

O ano de 1985 se iniciou com um desafio no que dizia respeito à estabilização econômica, continuar o crescimento iniciado no ano anterior, 1984. Ainda que em 1985, o valor das exportações tivesse retrocedido em $5,1 \%$, o superávit comercial permaneceu elevado, dado o encolhimento das importações (AVERBUG, 2005, p. 216), o que garantiu, naquele ano, um crescimento ao país, segundo dados do IBGE, de 7,8\%. 
O IPC da FIPE iniciou o mês de janeiro de 1985 na casa dos 10\%, permanecendo durante quase todo o ano em patamares inflacionários de 9 a $11 \%$, mas ao final do mesmo ano, em novembro e dezembro, o índice chegou à cerca de $13 \%$.

De acordo com Bresser Pereira (1986), a inflação brasileira, no segundo semestre de 1985, sofreu nova aceleração e a única maneira de eliminar a inflação inercial seria o congelamento geral de preços e a reforma monetária, também conhecida por choque heterodoxo.

Pio (2001, p. 32), escreveu a respeito da formulação heterodoxa brasileira:

\begin{abstract}
Uma especificidade sobre a duração de taxas anuais de inflação de dois/três dígitos por tanto tempo foi à instituição de um complexo sistema de indexação (pós-fixada) que atravessava toda a economia — de impostos a instrumentos financeiros e de salários a preços. No entanto, se a indexação evitava distúrbios contratuais de curto prazo causados pela inflação, também criava enormes dificuldades para os programas de combate à inflação (...) Nesse contexto, programas ortodoxos de estabilização foram implementados sem nenhum sucesso de 1980 a 1985, parte do tempo (1983-85) sob a rígida supervisão do FMI. Tais políticas não foram exitosas porque não levaram em conta a necessidade de desmantelar o sistema de indexação (...) Para os economistas heterodoxos, a eliminação do componente inercial da inflação requeria o uso de um artifício para coordenar as expectativas dos agentes economicos no sentido de uma situação de estabilidade de preços. Esse artifício estabeleceria, essencialmente, os valores iniciais (entry values) dos novos contratos (não-indexados) que substituiriam aqueles que continham cláusulas de indexação.
\end{abstract}

Bresser Pereira (1986) relata que a decisão de realizar o choque heterodoxo no dia 28 de fevereiro de 1986 foi apressada pelos altos índices de inflação de janeiro, que se confirmaram no mês seguinte. O IPC começou o ano de 1986 perto dos $14 \%$, seguido de cerca de $11 \%$ no mês subseqüente.

Averbug (2005) contextualiza que além da inflação alta no início de 1986, outros dois fatores contribuíram para um clima tenso na economia do país:o fato do governo não apresentar ainda nenhum plano de combate à inflação; e o desenvolvimento de várias greves trabalhistas, o que demonstrava a insatisfação popular quanto ao andamento da economia, já que o reajuste salarial não conseguia acompanhar o reajuste dos demais preços.

Em 28 de fevereiro de 1986, foi implantado o Plano Cruzado e uma nova moeda foi introduzida no mercado em substituição ao até então vigente cruzeiro, o cruzado. 
Gremaud, Vasconcellos e Toneto Jr. (2004) descreve que as regras de preços e salários foram definidas na tentativa de não piorar o padrão de distribuição de renda do cruzeiro e, de acordo com Bresser Pereira (1986, p. 11), as quatro medidas básicas adotadas pelo plano foram:

1) Congelar todos os preços, salários e taxas de câmbio nesse dia (28 de fevereiro de 1986);

2) Desindexar a economia;

3) Introduzir uma nova moeda, o cruzado, que substituiu o cruzeiro, da qual foram retirados três zeros;

4) Converter os contratos a prazo (salários, obrigações, aluguéis, taxas escolares, prestações de venda da casa própria) de cruzeiro em cruzados através de fórmulas que garantissem a recomposição do preço médio real dos últimos doze meses.

Averbug (2005) expõe que o fato do governo ter implantado um choque heterodoxo foi uma verdadeira surpresa para o país, e a meta de tal plano passa a ser a inflação zero. Como demonstrado na Figura 2, após a implantação do Plano Cruzado, a inflação se reduz e passa a atuar durante quase todo o ano no patamar de 1 a $2 \%$ mensais. Porém, em novembro de 1986, ela se eleva para $4 \%$ e termina o ano no patamar de mais de $10 \%$.

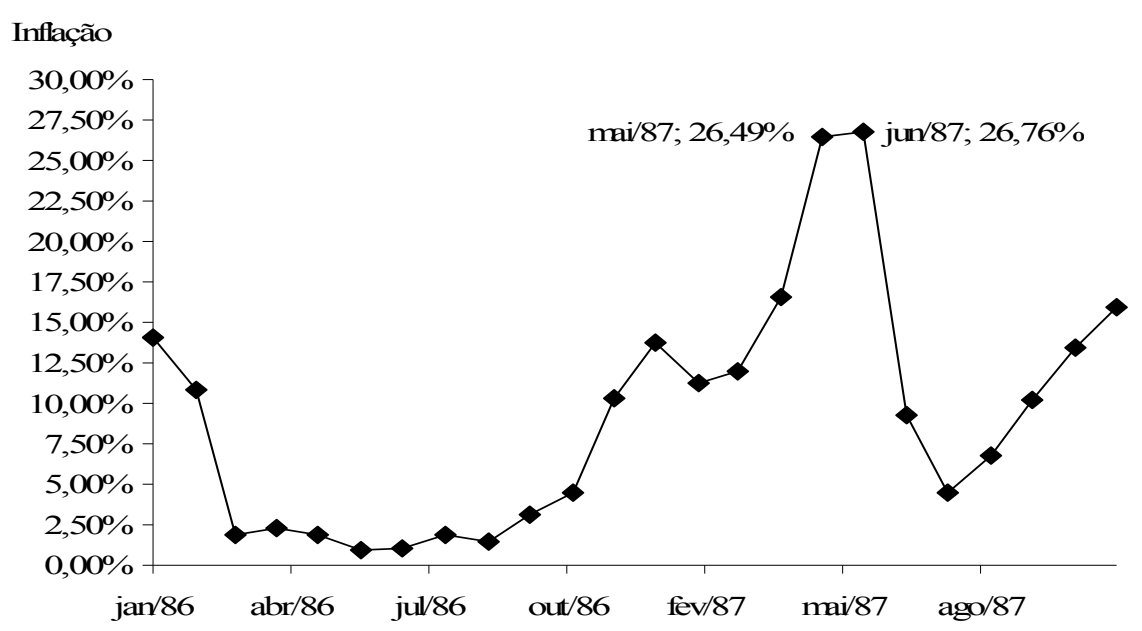

Figura 2: IPC mensal de Jan/1986 a Dez/1987.

Fonte: Elaborado pela autora a partir de dados da FIPE. 
Averbug (2005) resume a situação do país, a respeito dos efeitos no mercado de capitais, durante o plano:

Os recursos canalizados à bolsa de valores poderiam ter sido fonte de financiamento ao investimento se utilizados na compra de ações primárias, resultantes de novos lançamentos. Porém, privilegiaram aquelas já em poder do público, promovendo apenas uma transferência de posse e tendência à valorização das cotações. Se essa valorização tivesse perdurado por longo tempo, talvez conseguisse induzir mais empresas a recorrerem ao aumento de capital, via lançamento de ações, como forma de financiar seus investimentos.

O congelamento de preços trouxe como conseqüências imediatas a volta do crescimento econômico (o Brasil cresceu perto dos 8\% (IBGE) no ano de 1986), e o aumento do consumo (AVERBUG, 2005). Esse aumento do consumo dificultou a manutenção de um plano de congelamento de preços, já que elevou a demanda interna.

O resultado do aumento dessa demanda interna foi a pressão sobre diversos mercados, principalmente o de alimentos, causada pelo aumento de renda real dos trabalhadores, gerando escassez de alguns produtos, como carne e leite. A escassez de determinados produtos no mercado fez com que os mesmos fossem vendidos "fora" do preço tabelado pelo governo. Para a aquisição de carne, por exemplo, o consumidor deveria pagar um ágio sobre o preço de tabela estipulado pelo governo, o que dificultava assim, o congelamento de preços.

Então, após as eleições de novembro de 1986, o governo implantou um novo pacote econômico, denominado de Plano Cruzado II, que tinha como principais objetivos controlar o déficit público, conter o consumo e reduzir as pressões inflacionárias.

Como pode ser percebido na Figura 2, o ano de 1987 inicia-se com a volta da inflação em patamares elevados. Nos dois primeiros meses do ano, o IPC estava em torno de 14 e $12 \%$ e atinge em março o equivalente a $17 \%$. Essa volta da inflação, em níveis mais altos do que apresentados anteriormente, sem mecanismos de indexação, gerou instabilidade econômica e financeira no país. 
De acordo com Gremaud, Vasconcellos e Toneto Jr. (2004, p. 442), a certeza em relação à inflação resultou na ampliação da taxa real de juros, pois a incerteza inflacionária era incorporada à taxa nominal de juros. A taxa SELIC, que corresponde a taxa meta para financiamento dos títulos públicos federais, conhecida como taxa básica de juros da economia, em janeiro de 1987, estava em cerca de $116 \%$ ao ano.

Em abril de 1987, a inflação chegou a índices próximos dos $20 \%$ mensais, conforme apresentado na Figura 2, mostrando que o Plano Cruzado não havia conseguido cumprir seu objetivo, que era o que de controlar a inflação. O ministro da fazenda na ocasião, Adílson Funaro, pediu demissão do cargo, assumindo, então seu lugar, o economista Bresser Pereira, que enfrentou no mês de maio, uma inflação de quase $30 \%$.

Chegava ao fim o primeiro plano econômico da Era Sarney. Gremaud, Vasconcellos e Toneto Jr. (2004) atribuem o fracasso do plano à alta duração do congelamento de preços. Esse longo congelamento provocou o crescimento descontrolado da demanda e o descaso pelas contas externas. Averbug $(2005$, p. 239) descreve que a economia nacional não resistiu à solidão e à exaustão do Plano Cruzado, resultantes da ausência de políticas globais integradas e, nos momentos oportunos, de estratégias complementares.

Em 30 de junho de 1987, o ministro Bresser Pereira fez um pronunciamento na Câmara dos Deputados relembrando os percalços pelo qual passou o Plano Cruzado e as causas que levaram ao seu fracasso, em abril do mesmo ano. Nesse mesmo pronunciamento, o então ministro, esclareceu as diretrizes básicas e medidas que estavam sendo tomadas no combate à inflação, no chamado Plano Bresser, anunciado em 12 de junho de 1987.

Bresser expôs, em seu pronunciamento, que os objetivos básicos do governo do qual, naquele momento, fazia parte, eram os seguintes:

1) garantir o desenvolvimento econômico e o pleno emprego; 
2) distribuir de forma justa a renda entre as famílias e as regiões;

3) combater a inflação e lograr uma razoável estabilidade de preços;

4) alcançar um superávit comercial que permita ao país negociar sua dívida externa de forma soberana.

Para conseguir atingir os objetivos desejados, o ministro esclareceu que o novo plano de estabilização contava com várias medidas já postas em ação e com outras ainda em elaboração, dentre as quais as principais eram: medidas para aumento das exportações; Plano de Negociação da Dívida Externa; Novo Plano Cruzado; medidas de apoio a pequenas e médias empresas e um Plano de Controle Macroeconômico.

Também foi proposto um congelamento de preços por um tempo determinado de três meses, acompanhado do congelamento dos salários no mesmo período e congelamento de aluguéis.

Como observado na Figura 3, o período do Plano Bresser que vai de abril a dezembro de 1987, conseguiu diminuir a inflação apenas nos três meses subseqüentes à implantação do plano, mesmo período em que os preços e salários mantiveram-se congelados. No período de julho, agosto e setembro de 1987, o IPC saiu do patamar dos $26 \%$ em junho, para, respectivamente, $9,24 \%, 4,45 \%$ e $6,73 \%$. 


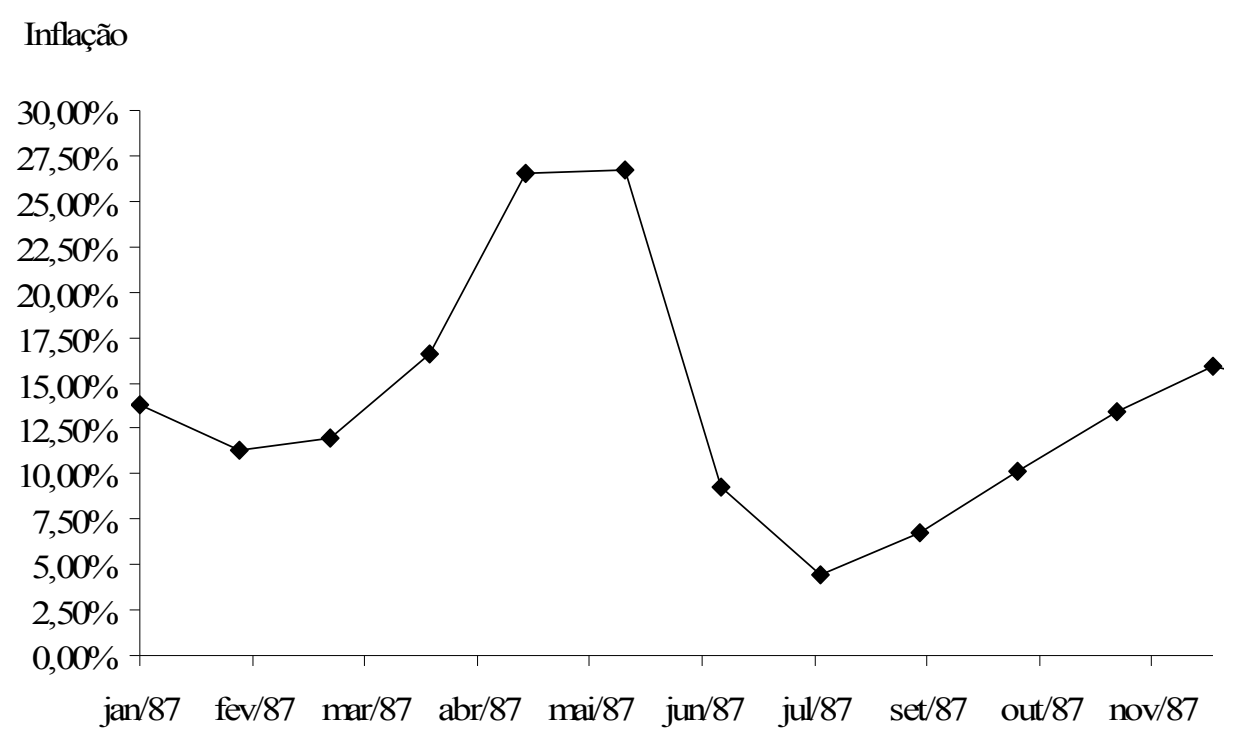

Figura 3: IPC mensal de Jan.a Dez/1987

Fonte: Elaborado pela autora a partir de dados da FIPE.

Houve uma queda significativa na produção industrial, no período do Plano Bresser, o que elevou os custos de produção (que foram repassados aos preços), e trouxe de volta a inflação. Com a aceleração inflacionária, surgiram pressões por reposições salariais. Como alguns setores conseguiram a reposição, iniciando-se no funcionalismo público, principiou-se o fracasso na contenção do déficit público, além do declínio do plano, que possuía como base a contenção salarial e a elevada taxa de juros.

Em outubro de 1987, a inflação voltou para a casa dos dez pontos percentuais e terminou dezembro em torno de 16\%, conforme Figura 3. A inflação acumulada do ano de 1987 foi de cerca de $350 \%$ e o crescimento econômico do ano caiu para a base de 3,5\% (IBGE), sendo que o objetivo inicial do Plano Bresser era permanecer em taxas acima de 7\%.

Devido ao fato do plano não ter conseguido atingir com êxito seus objetivos, em dezembro de 1987 o Ministro Bresser Pereira pediu demissão do cargo, assumindo o Ministério da Fazenda, Maílson da Nóbrega. 
O Ministro Maílson da Nóbrega ,em 3 de janeiro de 1988, adotou uma política econômica conhecida como "arroz com feijão". A política não prometia nenhum milagre e visava conter a aceleração inflacionária.

Conforme mostrado na Figura 4, essa política manteve o primeiro semestre com índices de inflação pouco oscilantes, com números entre 15 e 20\%, mas, no segundo semestre, a inflação disparou e terminou o ano perto de $30 \%$, gerando uma inflação acumulada no ano próxima de 1.000\%. O ano de 1988 terminou com crescimento econômico negativo, em torno de $-0,1 \%$ (IBGE).

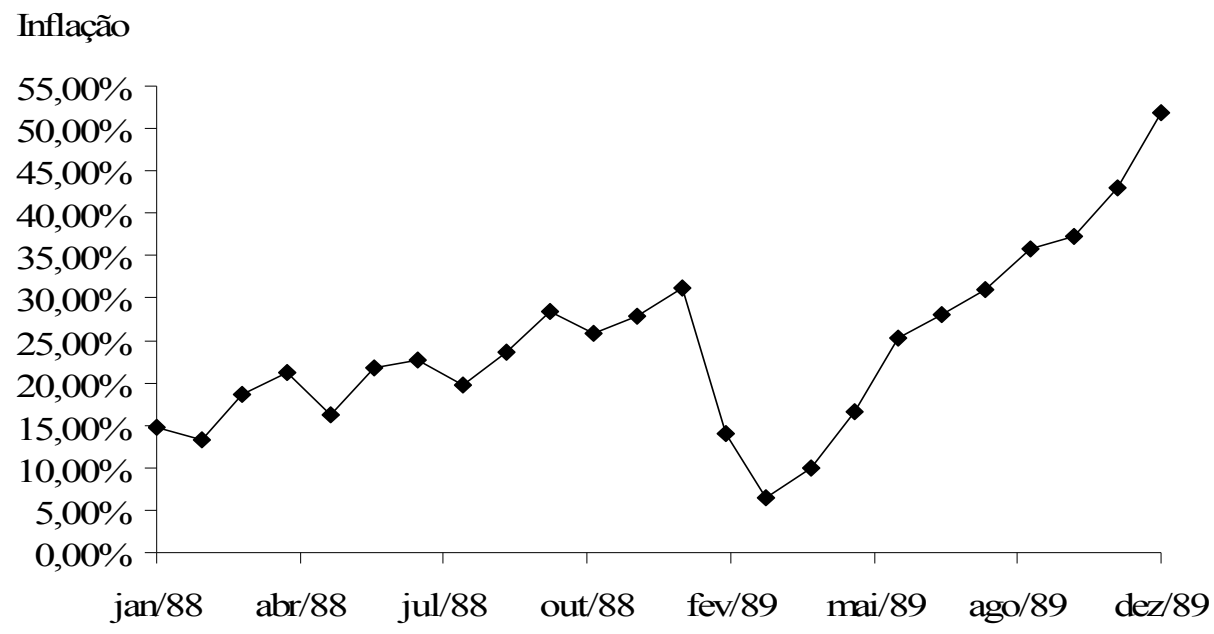

Figura 4: IPC mensal de Jan/1988 a Dez/1989.

Fonte: Elaborado pela autora a partir de dados da FIPE.

Em janeiro de 1989, a inflação superou os 30\% mensais e o governo implantou, então, um novo plano econômico denominado Plano Verão, que se iniciou em 14 de janeiro de 1989, visando mais uma vez conter a inflação.

As medidas tomadas em relação ao novo plano foram:

1) Congelamento de Preços; 
2) Reforma monetária com a introdução da moeda Cruzado Novo, a partir do corte de três zeros no cruzado;

3) Os salários foram convertidos pela média dos últimos doze meses mais a aplicação da URP (Unidade Referencial de Preços) de janeiro, o que gerava perda salarial, pois a URP era um índice de correção monetária pré-fixada para reajuste de três meses, baseada na média de inflação dos três meses anteriores;

4) Foi estabelecido taxa de câmbio fixa, em que um cruzado novo $(\mathrm{NCz} \$ 1,00)$ era igual a um dólar (US\$ 1,00);

5) Nenhum ajuste fiscal foi realizado, o que manteve os crescentes déficits públicos.

Bresser Pereira (1991) ainda esclarece que o Plano Verão tentou adotar uma política ortodoxa, colocando a taxa real de juros num nível muito elevado, e completa:

Se a taxa real de juros for maior que a taxa de crescimento do PIB (o que é muito fácil de acontecer, dado que o país está estagnado), e se ela tiver que ser financiada através do aumento do endividamento interno, a dívida interna aumentará de tal modo que os agentes econômicos desenvolverão expectativas negativas quanto ao seu futuro pagamento. Nos primeiros dois meses do Plano Verão, quando o governo brasileiro decidiu aumentar a taxa real de juros a níveis muito elevados, as conseqüentes perdas de confiança no governo e de crédito do Estado alcançaram seus pontos máximos, a fuga de capitais e o déficit público aumentaram e a iminência de uma hiperinflação se tornou evidente.

A Figura 5 ilustra a oscilação nas taxas reais de juros, no período de março de 1986 a fevereiro de 2006. O aumento nas taxas reais de juros, definido por Bresser Pereira (1991) como um "aumento artificial", no segundo semestre de 1989, está em destaque na figura. 


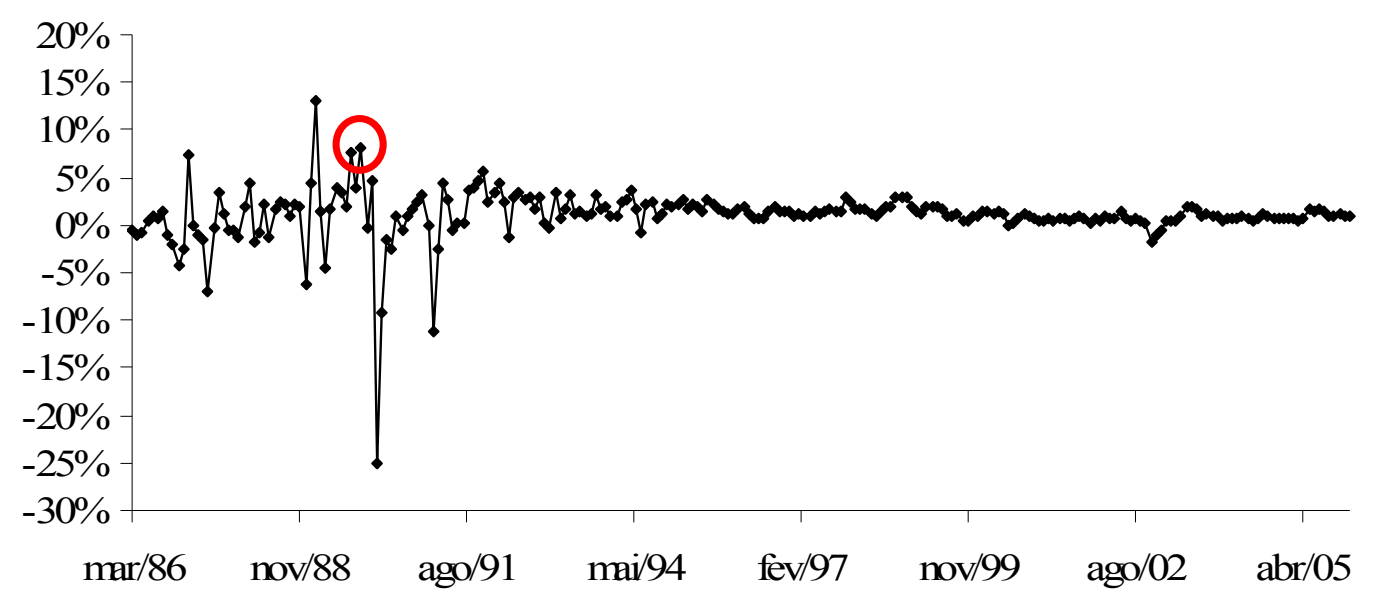

Figura 5: Taxas Reais de Juros (março/1986 a fevereiro/2006)

Fonte: Elaborado pela autora a partir de dados do Banco Central e da FIPE ${ }^{1}$.

O Plano Verão foi um plano de curta duração devido, principalmente, às eleições no final de 1989.

No segundo semestre de 1989, a taxa de inflação disparou de tal maneira que o ano terminou com um IPC mensal próximo de 55\%, gerando crescimento do produto real de 3,5\%, sugerindo que o governo Sarney não obteve êxito em nenhuma de suas tentativas de conter a inflação.

Foi nesse cenário de instabilidade econômica, déficit público elevado e hiperinflação que se findou a Era Sarney e teve inicio o governo Collor.

\footnotetext{
${ }^{1}$ Taxa SELIC descontada a Inflação (representada pelo IPC- FIPE).
} 


\subsubsection{Governo Collor - Planos Collor I e II}

Os três primeiros meses do ano de 1990 foram marcados pela hiperinflação. Em janeiro e fevereiro desse ano, o IPC apresentou variação em torno de $70 \%$, mas o recorde inflacionário histórico veio em março do mesmo ano, com uma taxa de inflação mensal de 82,19\%, conforme mostrado na Figura 5. O presidente eleito de forma direta ao final de 1989 foi Fernando Collor de Mello, que tomou posse no dia 15 de março de 1990. Collor nomeou para o Ministério da Fazenda sua antiga assessora, Zélia Cardoso de Melo.

Ao tomar posse, em março de 1990, o governo Collor implantou um novo plano de estabilização que, segundo Carvalho (2006), incluía limitação ou cancelamento da liquidez de haveres monetários (moeda manual e depósitos à vista) ou da conversibilidade de haveres financeiros em moeda. O plano conhecido como Plano Collor I bloqueou grande parte dos haveres financeiros, reduzindo em grande parte a liquidez da economia.

A medida provisória que deu sustentação ao Plano Collor, bloqueava quase $90 \%$ de todos os haveres financeiros, ficando disponível para saque em contas corrente ou caderneta de poupança o valor de cinqüenta mil, convertidos à nova moeda, o cruzeiro. Para valores em aplicação financeiras, apenas $20 \%$ do total poderia ser resgatado. O governo prometia devolver os haveres bloqueados ao público, com juros e correção monetária, dezoito meses após o início do plano.

O Plano também visava um novo congelamento de preços e desindexação dos salários em relação à taxa de inflação passada, mudança do regime cambial para sistema de taxas flutuantes, e mudança da política comercial, dando início ao processo de abertura comercial, através da redução de tarifas de importação (GREMAUD, VASCONCELLOS E TONETO JR., 2004). 
A Figura 6 mostra que, logo após o pronunciamento do novo plano, a inflação diminuiu, mas, a partir de maior de 1990 e até fevereiro do próximo ano, percebeu-se uma nova aceleração inflacionária, com taxas crescentes. O PIB no ano de 1990 registrou uma queda de 4,5\%, o que gerou recessão econômica.

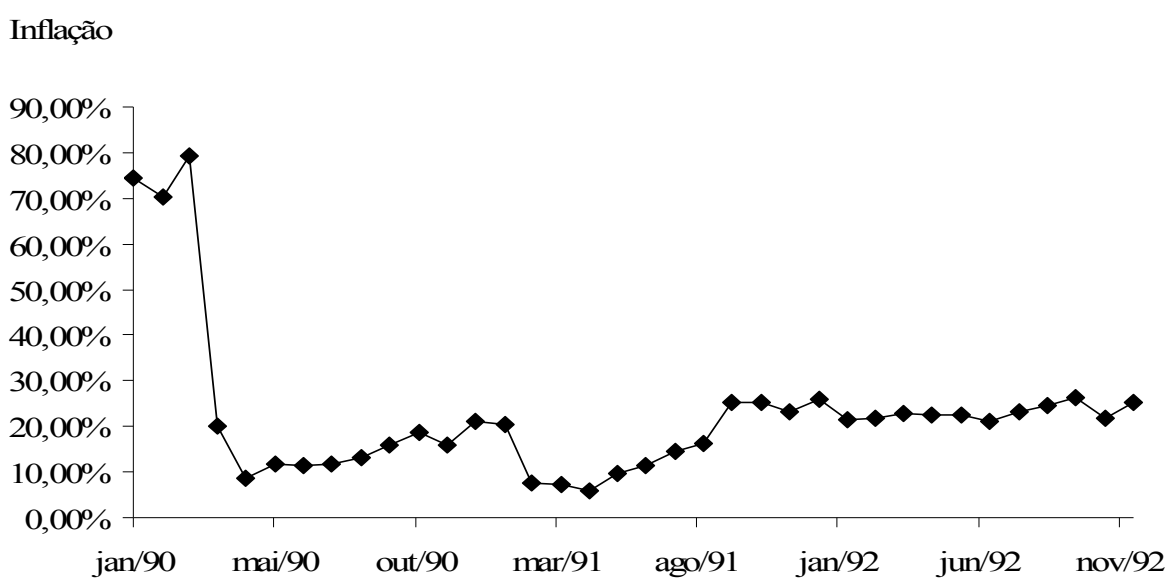

Figura 6: IPC mensal de Jan/1990.a Dez/1992.

Fonte: Elaborado pela autora a partir de dados da FIPE.

Segundo Gremaud, Vasconcellos e Toneto Jr. (2004, p. 452), “antes do plano o objetivo de controlar as taxas de juros levou à introdução do mecanismo de zeragem automática, que garantia a adequação da oferta monetária à taxa de juros pretendida". De acordo com esse conceito, o Banco Central recomprava os títulos públicos que as instituições financeiras não conseguiam vender ao público.

Para Cerqueira (2006), devido a esse mecanismo de zeragem automática, a inflação era só uma questão de tempo. Além disso, o governo passou a permitir que determinados grupos retirassem recursos bloqueados antes do décimo nono mês, o que fez a liquidez retornar gradualmente, antes do prazo previsto. Devido à volta da inflação, em fevereiro de 1991 o governo implantou mais um plano de estabilização, denominado de Plano Collor II, ainda sob o 
ministério de Zélia Cardoso de Melo, que permaneceu até maio, quando foi substituída pelo Ministro Marcílio Marques Moreira.

Esse novo plano promoveu um novo congelamento de preços e alterou as regras de indexação baseada na inflação passada, introduzindo uma taxa de juros referencial (TR) (CERQUEIRA, 2006). Como percebido na Figura 6, nos primeiros meses do novo plano a inflação retrocedeu, mas, a partir do segundo semestre de 1991, voltou a subir e terminou o ano em torno de $25 \%$ ao mês.

O ano de 1992 se iniciou sob um quadro de alta inflação e recessão. Dado que o ano anterior havia apresentado cerca de 1\% de variação no Produto Interno Bruto, 1992 terminou sob variação negativa no mesmo indicador, $-0,54 \%$ (IBGE).

Gremaud, Vasconcellos e Toneto Jr. (2004) relacionaram o comprometimento do desempenho fiscal à baixa arrecadação, às altas taxas de juros e ao quadro político desfavorável pelo processo de impeachment do presidente. Porém, essas altas taxas de juros somadas ao processo de abertura comercial promoveram uma grande entrada de capital externo no país, aumentando, consideravelmente, as reservas. Os planos também trouxeram à tona a questão da privatização, que foi colocado como elemento central do processo de ajuste fiscal do setor público.

De acordo com Carvalho (2006), o plano Collor acabou sendo lembrado apenas pelo bloqueio dos haveres financeiros, embora as demais medidas tenham influenciado mais profundamente o futuro do país, como a abertura comercial e a questão das privatizações.

No final do ano de 1992, o Presidente Fernando Collor de Mello sofreu o impeachment e o seu vice, Itamar Franco, assumiu a presidência. Empossado, em maio de 1993, o presidente Itamar Franco nomeou Fernando Henrique Cardoso para o ministério da fazenda. 


\subsubsection{Plano Real}

Após as tentativas dos governos anteriores em estancar a inflação do país, ao fim de 1993 começou a se articular um novo plano econômico, que teria um efeito definitivo sobre a aceleração inflacionária.

Fernando Henrique Cardoso, ao assumir o ministério da fazenda, em maio de 1993, deu início a um processo de implantação de condições macroeconômicas à estabilização, que se iniciou em dezembro do mesmo ano, apesar de pretendida para o ano seguinte. Como exposto na Figura 7, o ano de 1993 começou com a inflação próxima aos 30\% mensais e terminou o ano perto de $40 \%$ e, mesmo oscilando, em nenhum momento cedeu para menos de $25 \%$. O Brasil encerrou 1993 com crescimento econômico em torno de 5\% (IBGE).

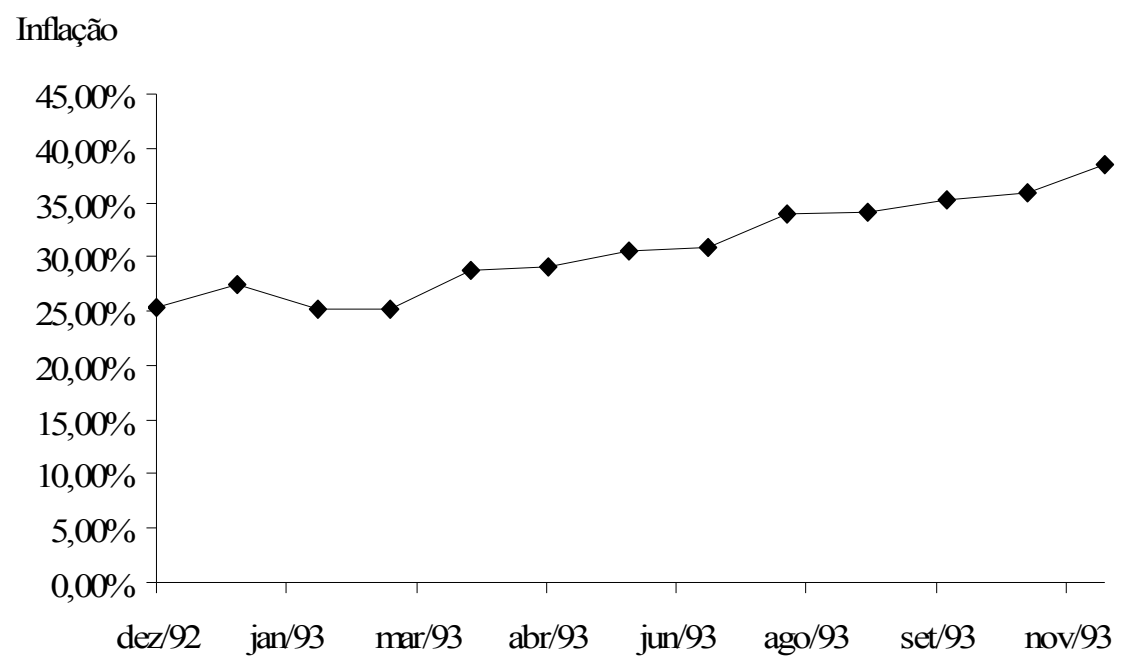

Figura 7: IPC mensal de Jan. a Dez/1993.

Fonte: Elaborado pela autora a partir de dados da FIPE.

Segundo Gremaud, Vasconcellos e Toneto Jr. (2004) a fim de combater o processo inflacionário o Plano Real se dividiu em três fases: a) ajuste fiscal, b) indexação completa da 
economia, URV (Unidade Real de Valor) e c) reforma monetária - transformação de URV em $\mathrm{R} \$$.

O ajuste fiscal visava equacionar o desequilíbrio orçamentário para os próximos anos e impedir que desse ponto ocorressem pressões inflacionárias (GREMAUD, VASCONCELLOS E TONETO JR., 2004, p. 469). Batista Jr (1996) acrescenta que a preocupação estava em conquistar credibilidade fiscal, já que era de domínio público entre imprensa e agentes econômicos, a opinião de que os planos anteriores haviam fracassado por falta de "ajuste duradouro nas contas públicas".

Ainda de acordo com Batista Jr (1996), visto dessa forma o ajuste fiscal contribuiria para a desaceleração da inflação, ao anunciar que o governo não mais se financiaria por meios inflacionários.

O governo baseava o ajuste fiscal em corte de despesas, aumento dos impostos e diminuição nas transferências do governo federal, através de ações como o Plano de Ação Imediata, que visava corte nos gastos públicos, criação do IPMF (Imposto Provisório sobre Movimentações Financeiras), que possuía uma alíquota de 0,25\% sobre todas as transações financeiras, e a criação de um Fundo Social de Emergência, que seria alimentado por 15\% da arrecadação de todos os impostos (GREMAUD, VASCONCELLOS E TONETO JR., 2004).

Para dar início a segunda fase do plano, o governo criou um novo indexador, a URV (Unidade Real de Valor). Este indexador teria seu valor reajustado diariamente pelos principais índices de preço do país, (IGPM, IPC e IPCA), e manteria paridade de "um pra um" com o dólar.

A terceira fase do plano consistia na criação de uma nova moeda, e isto foi feito após todos os preços estarem oficialmente convertidos em URV. No dia $1^{\circ}$ de julho de 1994 , começa a vigorar oficialmente a moeda denominada de Real (R\$), cujo valor de $\mathrm{R} \$ 1,00$ era de uma URV. 
A solução encontrada pelo governo foi, de acordo com Batista Jr (1996), adotar uma política monetária restritiva: a emissão monetária de reais não poderia ultrapassar $\mathrm{R} \$ 7,5$ bilhões até 30 de setembro de 1994, R\$ 8,5 bilhões até 31 de dezembro de 1994 e R $\$ 9,5$ bilhões até março de 1995.

Como apresentado na Figura 8, o Plano Real atingiu seu objetivo de combate à inflação, já que em junho de 1994, mês anterior à implantação do plano, a inflação atingiu a casa dos 50\%, reduzindo para cerca de $30 \%$ em julho e caindo em agosto para níveis próximos de $1 \%$. No ano de 1994, o Produto Interno Bruto apresentou variação real de 5,85\%, o que sinalizava que o país estava começando a crescer novamente.

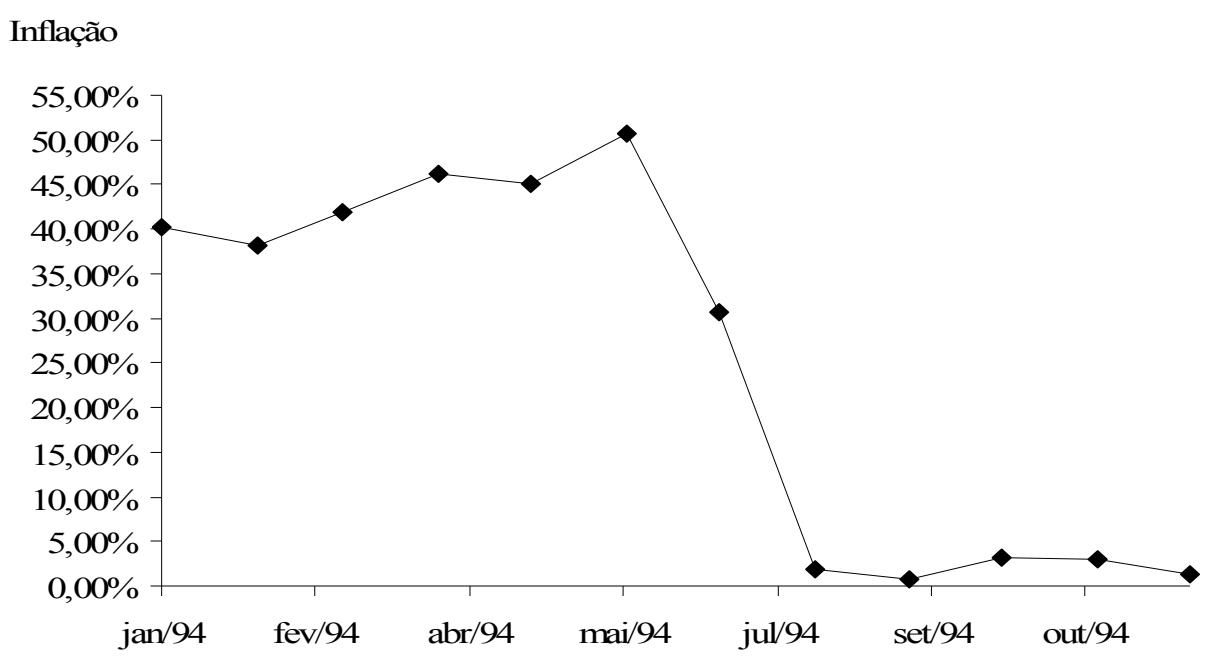

Figura 8: IPC mensal de Jan. a Dez/1994.

Fonte: Elaborado pela autora a partir de dados da FIPE.

Para Batista Jr. (1996), o Plano Real revelou grande eficácia em matéria de combate a inflação e resultou no alinhamento dos aspectos centrais da política econômica do país ao modelo de estabilização e integração internacional que na época, vinha sendo aplicado em outros países da América Latina, principalmente México e Argentina. Para Gremaud, Vasconcellos e Toneto Jr. (2004), a estratégia utilizada para estabilizar as economias foi a realização de uma reforma 
monetária através da "âncora cambial”, ou seja, fazendo com que a nova moeda tivesse uma taxa de câmbio fixa com o dólar.

Em relação ao sistema de âncora cambial adotado pelo Plano Real, Silva $(2002$, p. 6) o descreveu:

De fato, no caso brasileiro a paridade máxima entre o real e o dólar foi anunciada, oficialmente, no momento da implantação do Plano Real, como equivalente a R\$ 1 = US\$ 1 . O limite inferior não foi num primeiro momento oficialmente fixado. Entre julho e setembro de 1994 não houve qualquer intervenção no mercado de câmbio e a taxa de câmbio sofreu, de fato, uma apreciação, caindo para algo em torno de R \$ 0.85/US\$ 1 . Tendo em vista que as conseqüências da apreciação da moeda afetaram a balança de transações correntes, em setembro o Banco Central realizou sua primeira intervenção no mercado de câmbio e anunciou, em outubro, informalmente, que estaria disposto a comprar dólares a uma taxa mínima de R\$ 0.82/ US\$ 1 , e vender a uma taxa máxima de R \$ 0.86/US\$ 1 . Estava assim caracterizado um sistema 'informal' de bandas cambias tendo apenas um limite superior oficialmente determinado, mas um limite inferior implicitamente assumido, haja visto o comportamento da autoridade monetária.

Gremaud, Vasconcellos e Toneto Jr. (2004), esclarecem que todos os países que utilizaram uma taxa de câmbio para a estabilização sofreram valorização cambial devido à inflação residual não repassada ao câmbio num momento seguinte, o que acomodaria os preços internos aos internacionais. No Brasil, a valorização não se deu apenas em função da inflação residual, conforme exposto acima, mas também ao não se fixar a paridade de R\$1,00 para US\$ 1,00, como fez, por exemplo, a Argentina. Dessa forma foi permitido que o real se valorizasse em termos nominais em relação ao dólar, em um momento em que continuavam as entradas de recursos.

A taxa de câmbio permaneceu, nos primeiros anos, em torno de "um para um", subindo de 0,8 reais de dólar em agosto de 1994 até 1,2 reais de dólar em dezembro de 1998. Porém, em janeiro de 1999, o câmbio sofreu uma grande desvalorização, chegando em 1,98 reais de dólar. A partir de então, a taxa de câmbio passou a sofrer constantes desvalorizações e seu ápice se deu nas vésperas da eleição presidencial de 2002, cuja taxa atingiu $R$ \$ 3,89. Nos meses seguintes a desvalorização cambial cedeu e, em novembro de 2006, o câmbio estava em torno de R\$2,17. 


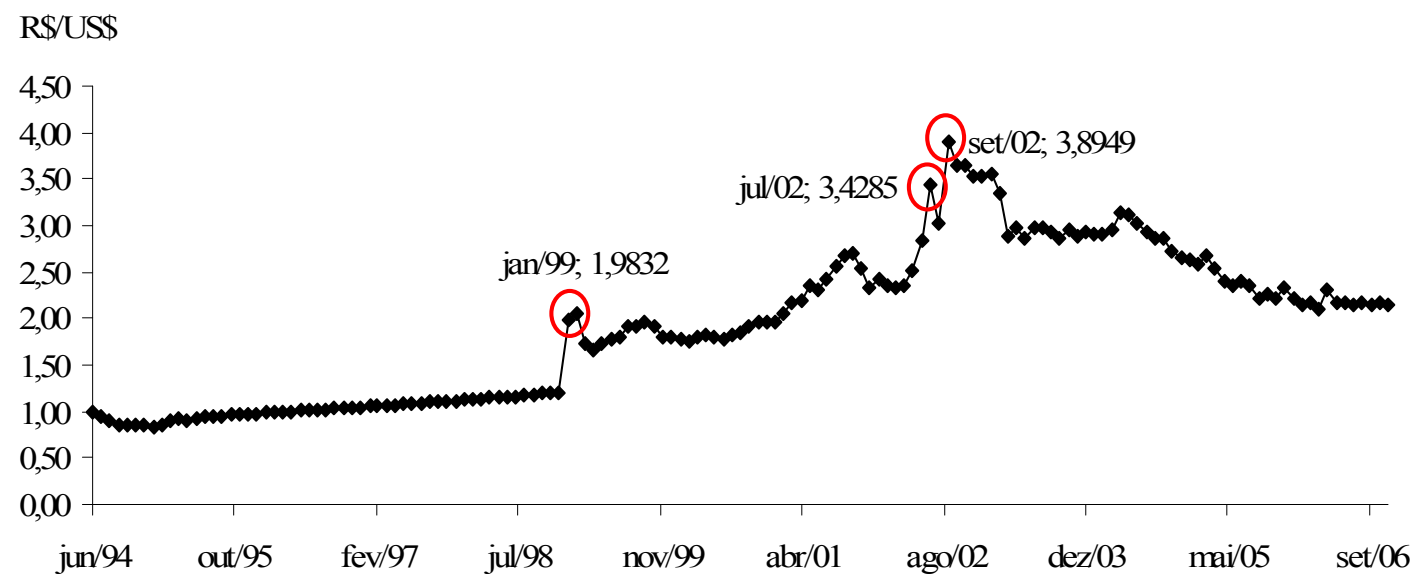

Figura 9: Taxa de câmbio comercial para venda: real (R\$) / dólar americano (US\$) - fim período (de Jun./1994 a Dez./2006).

Fonte: Elaborado pela autora a partir de dados do IPEAData2.

Já que o grande objetivo dos planos de estabilização econômica era o controle inflacionário, nesse sentido o Plano Real foi bem sucedido. Conforme exposto na Figura 10, após a implantação do plano, a inflação mensal permaneceu em baixos patamares, sendo que a maior variação mensal observada foi no mês de julho de 1995, atingindo 3,72\%.

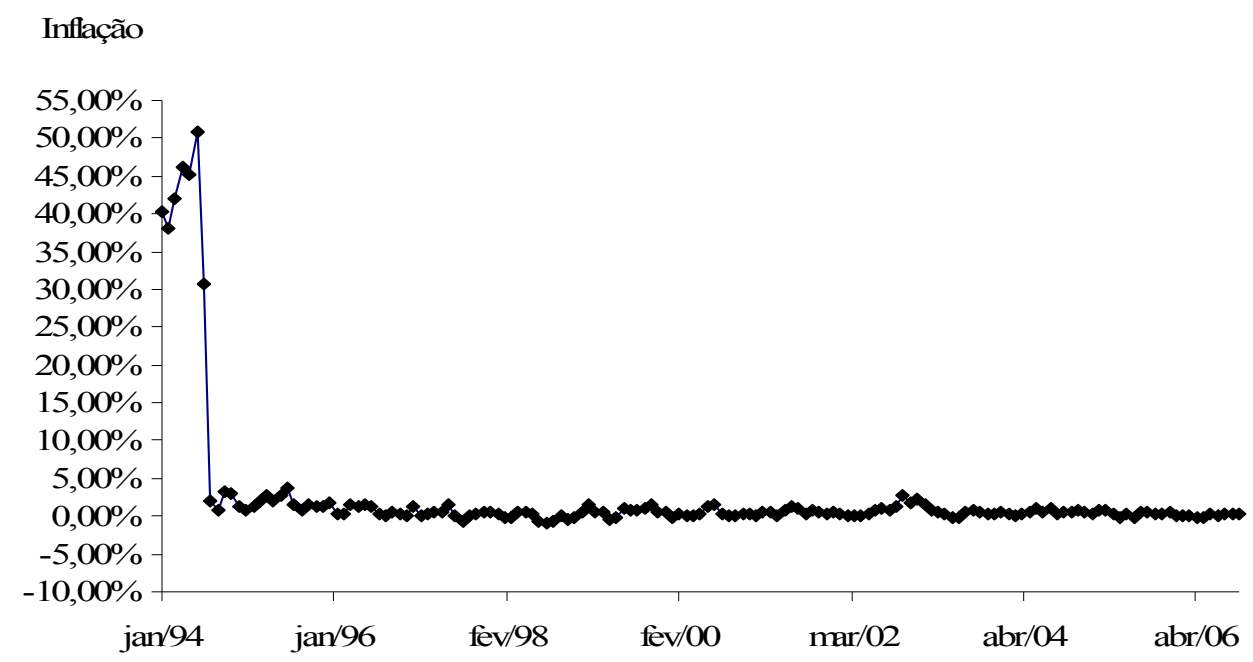

Figura 10: IPC mensal de Jan/1994 a Nov/2006.

Fonte: Elaborado pela autora a partir de dados da FIPE

2 Disponível em www.ipeadata.gov.br, acesso em 15/12/2006. 
De acordo a Figura 11, nos últimos doze anos após a estabilização da economia, o país apresentou taxas de crescimentos satisfatórias em determinados anos, as quais não conseguiram se sustentar nos anos seguintes. Como se pode observar, o ano de 2000 encerrou com crescimento de $4,36 \%$ e no ano seguinte, 2001, essa taxa foi de apenas $1,31 \%$. O mesmo ocorreu em 2004, em que o país apresentou variação real no Produto Interno Bruto próxima dos 5\%, para, em 2005, retornar à casa dos $2 \%$ de crescimento. Dado os números apresentados, percebe-se que o grande desafio da economia brasileira continua sendo o crescimento econômico.

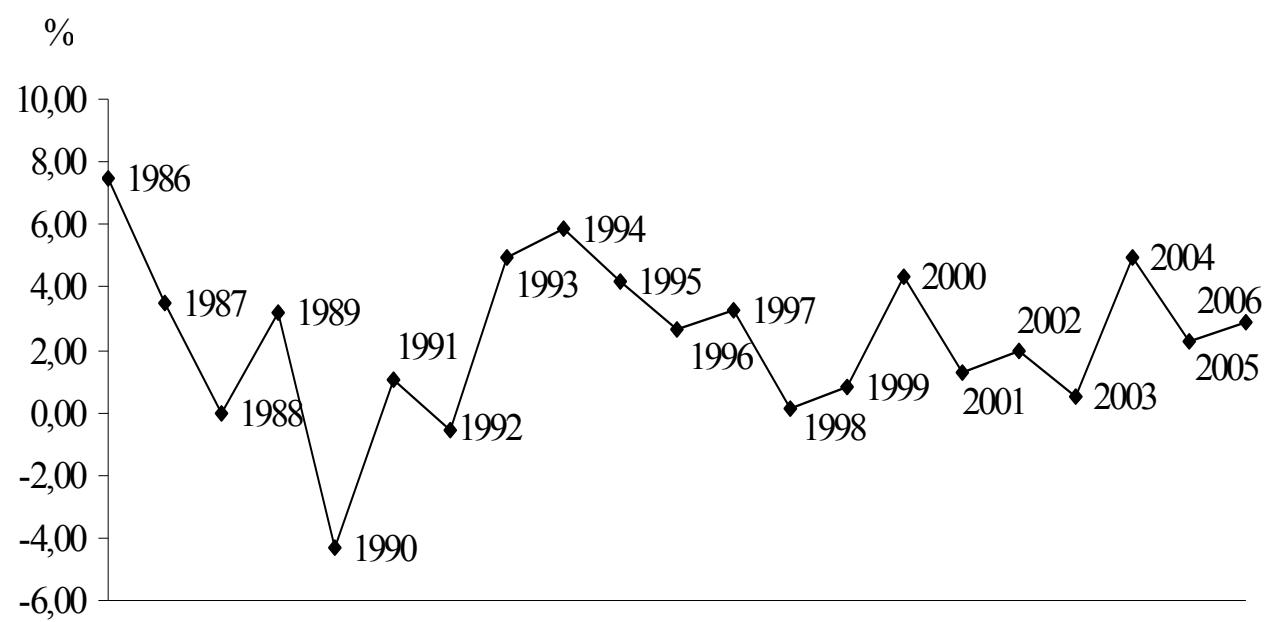

Figura 11: Variação Real do Produto Interno Bruto (de 1986 a 2006) Fonte: Elaborado pela autora a partir de dados do IPEAData ${ }^{3}$

Com base nas oscilações macroeconômicas dos diferentes planos descritos neste tópico do capítulo, o presente trabalho analisará a volatilidade do mercado de renda fixa e renda variável no Brasil, nos últimos vinte anos (de 1986 a 2006), esperando, assim, contribuir para uma melhor compreensão em torno no tema.

\footnotetext{
${ }^{3}$ Disponível em www.ipeadata.gov.br, acesso em 21/04/2007.
} 


\subsection{Volatilidade dos Retornos dos Ativos}

Uma das questões mais relevantes em finanças, segundo Jorion (2003), é a questão do risco dos ativos financeiros ao longo do tempo. Ao tomar a decisão de como alocar um ativo é necessário tentar prever o risco do investimento, e esse risco pode ser entendido como a volatilidade dos resultados não esperados, ou mais genericamente, refere-se a possíveis perdas nos mercados financeiros.

A decisão tomada pelo investidor ou gestor de portfólio, de como alocar uma carteira de ativos, depende do retorno ou da previsão de ganho futuro ao se adquirir tais ativos e, conseqüentemente, do risco a que esse retorno está relacionado. Para o conhecimento do risco há a necessidade de se medir a volatilidade do ativo, ou mais precisamente, o comportamento dos retornos desse ativo ao longo do tempo.

Para Fernandes e Mota (2004), o estudo da volatilidade tem grande importância na área de finanças, em especial no apreçamento de derivativos e no gerenciamento de risco. Dario (2004, p.1) define a volatilidade de um ativo como a medida mais simples para mensurar a incerteza quanto ao seu valor no futuro.

Reilly e Norton (2006) argumentam que os riscos surgem da volatilidade esperada do retorno de um determinado ativo sobre o tempo, e que as causas desses riscos são as flutuações da renda estimada, flutuações na expectativa futura do preço do ativo e flutuações no retorno do investimento.

Alexander $(2005$, p.4) ainda esclarece que é difícil prever as variações nos preços dos ativos financeiros e, à medida que o prazo aumenta, cresce a incerteza em relação ao retorno desses ativos. Assim, a distribuição desses retornos torna-se mais dispersa, o que implica dizer 
que eleva a sua variância. A medida mais comum de dispersão é o desvio padrão $(\sigma)$ de uma variável aleatória, isto é, a raiz quadrada de sua variância.

Gabe e Portugal (2003, p.1) explicam que a maioria dos modelos de previsão da volatilidade estatística se apóia no comportamento passado dos preços dos ativos, ou seja, são, por natureza, de indução retroativa. Então, de acordo com os autores, muitas pesquisas têm tentado determinar qual o melhor estimador de volatilidade para variáveis dos mercados financeiros.

Alexander (2005, p. 12), resume que a "verdadeira volatilidade" dificilmente será prevista ex-ante, pois a mesma é afetada por qualquer movimento do mercado, que pode ocorrer a qualquer momento dentro do horizonte de risco do modelo. Para o autor, então,

[...]se a volatilidade de uma variável do processo estocástico for constante, então a volatilidade verdadeira será usada pelo desvio padrão amostral dos retornos observados. Se o processo estocástico da variável tem uma volatilidade variável no tempo, controlada por um modelo GARCH, então a volatilidade verdadeira será aquela do modelo GARCH, estimada ao longo do período de dados históricos.

Morais e Portugal (1999) afirmam que a medida mais usada para conhecimento da volatilidade histórica de um ativo é o desvio padrão dos retornos em um determinado período de tempo, e, segundo Stock e Watson (2004), o desvio padrão dos retornos é a raiz quadrada da variância dos retornos, sendo essa variância um estimador da variância da população.

O desvio padrão dos retornos de um ativo é dado por:

$$
\sigma=\sqrt{\frac{\sum_{i=1}^{n}\left(Y_{i}-\bar{Y}\right)^{2}}{n-1}},
$$

em que $Y_{i}$ representa o retorno o título, $\bar{Y}$ a média dos retornos da amostra e $n$ o número de retornos da amostra. 
Porém, os investidores e operadores do mercado financeiro não estão interessados apenas na identificação da volatilidade passada ou histórica dos ativos, eles a usam para entender o comportamento desses ativos no passado e, com isso, tentar prever as possíveis oscilações a que esses ativos estão sujeitos no futuro.

Alguns períodos possuem volatilidades mais baixas que outros, representando períodos mais tranqüilos. De acordo com Stock e Watson (2004, p. 382), a volatilidade ocorre em grupos, que podem ser pensados como grupos de variância do termo de erro ao longo do tempo, ou ainda, se o erro da regressão tem variância pequena em um período, sua variância tende a ser pequena no período seguinte também.

Os modelos que quantificam os grupos de volatilidade são conhecidos como de Heterocedasticidade Condicional, ou, mais genericamente, grupos de volatilidade implicam que o erro exibe heterocedasticidade variante no tempo e auto-correlacionada. (STOK e WATSON, 2004, p. 382).

Isso é o mesmo que dizer, segundo Alexander (2005, p. 68), que esses grupos de volatilidade do mercado financeiro representam a correlação positiva dos retornos ao quadrado, em que períodos tranqüilos de pequenos retornos são intercalados por períodos voláteis de grandes retornos, denominando-se esse fenômeno de Heterocedasticidade Condicional AutoRegressiva.

Assim sendo, para Alexander (2005), um simples método para detectar o agrupamento da volatilidade consiste em calcular o coeficiente de correlação de primeira ordem dos retornos ao quadrado. Stock e Watson (2004) definem que os dois modelos de grupos de volatilidade são os modelos $\mathrm{ARCH}$ (heterocedasticidade condicional auto-regressiva) e sua extensão. o modelo ARCH generalizado, GARCH. 


\subsubsection{Modelos ARCH e GARCH}

Robert Engle, desenvolveu o modelo ARCH em sua publicação sobre o comportamento da taxa de inflação do Reino Unido em 1982. No modelo ARCH, o erro $\varepsilon_{t}$ é modelado como normalmente distribuído, com média zero e variância $\sigma_{t}^{2}$, em que $\sigma_{t}^{2}$ depende do quadrado de valores passados de $\varepsilon_{t},\left(\varepsilon_{t-1}\right)$ e $\alpha_{0}, \alpha_{1}, \ldots, \alpha_{p}$ são coeficientes desconhecidos (STOCK e WATSON, 2004).

O modelo determina que a variância condicional presente seja a média ponderada dos retornos ao quadrado não esperados do passado, e,conforme Stock e Watson (2004, p. 383), um modelo $\operatorname{ARCH}(p)$ é representado da seguinte forma:

$$
\sigma_{t}^{2}=\alpha_{0}+\alpha_{1} \varepsilon_{t-1}^{2}+\alpha_{2} \varepsilon_{t-2}^{2}+\ldots+\alpha_{p} \varepsilon_{t-p}^{2}
$$

Se os coeficientes $\alpha_{0}, \alpha_{1}, \ldots, \alpha_{p}$ são maiores que zero, e os quadrados dos erros recentes são grandes, o modelo ARCH prevê que o quadrado do erro corrente será grande em magnitude e que sua variância, $\sigma_{t}^{2}$, é grande (STOCK e WATSON, 2004).

O processo $\operatorname{ARCH}(p)$ captura a heterocedasticidade condicional dos retornos financeiros, segundo Alexander (2005, p. 76), “admitindo que a variância condicional de hoje seja a média ponderada dos retornos ponderados ao quadrado não esperados do passado.”

Porém, os modelos GARCH simples funcionam melhor para retornos de ativos do mercado financeiro que o modelo ARCH. Alexander (2005) pontua que o modelo ARCH com coeficientes declinando exponencialmente é equivalente a um modelo $\mathrm{GARCH}(1,1)$. Os modelos $\operatorname{ARCH}(p)$ convergem para um modelo $\operatorname{GARCH}(1,1)$ conforme $\mathrm{p}$ aumenta. 
$\mathrm{O}$ modelo completo $\operatorname{GARCH}(p, q)$ adiciona $q$ termos auto-regressivos à especificação $\operatorname{ARCH}(p)$, de modo que a equação da variância condicional toma a seguinte forma (ALEXANDER, 2005):

$$
\begin{aligned}
& \sigma_{t}^{2}=\alpha_{0}+\alpha_{1} \varepsilon_{t-1}^{2}+\ldots+\alpha_{p} \varepsilon_{t-p}^{2}+\beta_{1} \sigma_{t-1}^{2}+\ldots+\beta_{q} \sigma_{t-q}^{2} \\
& \alpha_{0}>0, \alpha_{1}, \ldots, \alpha_{p}, \beta_{1}, \ldots, \beta_{q} \geq 0
\end{aligned}
$$

onde $\beta_{1} \ldots \beta_{q}$ são os termos auto-regressivos. Como raramente é necessário usar mais que um modelo $\operatorname{GARCH}(1,1)$, que possui um único erro ao quadrado e um termo auto-regressivo, o modelo seria dado por:

$$
\begin{gathered}
\sigma_{t}^{2}=\omega+\alpha \varepsilon_{t-1}^{2}+\beta \sigma_{t-1}^{2}, \\
\alpha_{0}=\omega>0, \alpha, \beta \geq 0,
\end{gathered}
$$

tornando-se o modelo $\mathrm{GARCH}(1,1)$ equivalente a um modelo $\mathrm{ARCH}$ infinito com pesos declinando exponencialmente.

\subsubsection{Testes Dickey Fuller (DF) e Dickey Fuller Aumentado (ADF)}

Em um modelo de heterocedasticidade condicional auto-regressiva é admitida a hipótese de que os retornos sejam gerados por um processo estocástico, com uma volatilidade variável no tempo (ALEXANDER, 2005).

Gujarati (2000, p. 719) afirma que "um processo estocástico que tem recebido grande atenção por parte dos analistas de séries temporais é o chamado processo estocástico estacionário, que consiste em dizer que se o processo for estacionário, as médias e variâncias são constantes ao longo do tempo". Se observações sucessivas são dependentes, a volatilidade futura pode ser 
prevista com base nas observações passadas. Para Stock e Watson (2004, p. 303), "se o futuro é igual ao passado, então as relações históricas das séries temporais podem ser utilizadas para prever o futuro, mas se o futuro difere fundamentalmente do passado, essas relações históricas podem não ser guias confiáveis para o futuro".

Ainda de acordo com Stock e Watson (2004, p. 304), "no contexto de regressão das séries temporais, a idéia de que as relações históricas podem ser generalizadas para o futuro é formalizada pelo conceito de estacionariedade (...), uma série temporal é estacionária se a sua distribuição de probabilidade não muda ao longo do tempo".

Os testes estatísticos denominados de "testes de raízes unitárias" são os relativos à hipótese nula $(\alpha=1)$, de que a série temporal não é estacionária, contra a hipótese alternativa $(\alpha<$ 1), de que a série é estacionária (ALEXANDER, 2005, p. 353).

Segundo Sartoris (2003), para testar a hipótese nula de $\alpha=1$, pode-se realizar o teste proposto por Dickey e Fuller (DF), que chegaram a valores limites que são válidos para quando se testa a hipótese (de que $\alpha=1$ ). De acordo com o teste DF, subtraindo-se $y_{t-1}$ de um modelo do tipo $\operatorname{AR}(1)$, tem-se:

$$
\begin{gathered}
y_{t}=c+\alpha y_{t-1}+e_{t} \text { (equação de um modelo do tipo AR(1)) } \\
y_{t}-y_{t-1}=c+\alpha y_{t-1}-y_{t-1}+e_{t} \\
\Delta y_{t}=c+(\alpha-1) \cdot y_{t-1}+e_{t} \\
\Delta y_{t}=c+\delta y_{t-1}+e_{t}
\end{gathered}
$$

onde $c$ é o termo constante da equação e $y_{t-1}$ a primeira defasagem da variável $y_{t}$ mais um termo de erro $e_{t}$. Testar se $\alpha=1$, equivale testar se $\delta=0$. O teste é feito computando-se a estatística $\mathbf{t}$ como se fosse um teste comum numa regressão qualquer, mas como os limites não são dados pela distribuição de Student, a estatística é denominada $\tau$, e o teste é conhecido como Dickey e Fuller. 
Ainda de acordo com Sartoris (2003), o teste Dickey e Fuller, assim formulado, testa apenas a raiz unitária num processo do tipo $\mathrm{AR}(1)$. Para um processo $\mathrm{AR}(p)$ deve-se utilizar o teste Dickey e Fuller Aumentado (ADF), pois uma variável pode apresentar mais de uma raiz unitária.

Os testes $\mathrm{ADF}$ simplesmente adicionam variáveis defasadas à regressão $\mathrm{DF}$, e essas defasagens devem ser suficientes para se mover qualquer autocorrelação dos resíduos. As hipóteses são: $\mathrm{H}_{0}$ : $\beta=0$ contra $\mathrm{H}_{1}: \beta<0$, para o modelo:

$$
\Delta y_{t}=c+\alpha_{1} \delta y_{t-1}+\beta y_{t}+\ldots .+\alpha_{n} \delta y_{t-n}+e_{t}
$$

Segundo Stock e Watson (2004), sob a hipótese nula, $y_{t}$ possui uma tendência estocástica, o que seria o mesmo que dizer que esta tendência é aleatória e varia ao longo do tempo, ou a série pode apresentar um período prolongado de alta volatilidade, seguido por um período de declínio da mesma variável. Sob a hipótese alternativa $y_{t}$ seria estacionário.

A estatística ADF não possui uma distribuição normal, mesmo em amostras grandes, portanto, assim como no teste DF, os valores críticos usuais de uma distribuição normal não podem ser utilizados quando a estatística ADF é utilizada para testar a presença de raiz unitária, ao invés disso, deve ser utilizado um conjunto especial de valores críticos baseados na distribuição da estatística ADF sob a hipótese nula (STOCK E WATSON, 2004). 


\subsection{Estudos Anteriores}

\subsubsection{O estudo de Reilly, Wright e Chan (2000)}

Reilly, Wright e Chan (2000) realizaram o estudo da volatilidade dos ativos bonds e ações para o mercado americano. Os autores analisaram as mudanças na volatilidade do mercado de bonds e do mercado de ações para um período de cinqüenta anos (de janeiro de 1950 a dezembro de 1999), e as compararam, utilizando os desvios padrão anuais dos retornos diários e o modelo $\operatorname{ARCH}(1,1)$.

Os autores utilizaram o Ryan Labs Treasury Composite Bonds Index (RTI), que inclui todos os bonds do tesouro com a maturidade maior que um ano desde 1949, como o índice de renda-fixa. O RTI é um indicador que emprega a metodologia usada por outras três firmas de investimento: Lehman Brothers, Merrill Lynch e Salomon Smith Barney, conforme apresentado no Quadro 1: 


\begin{tabular}{|c|c|c|c|c|}
\hline Características & RTI & Lehman Brothers & Merrill Lynch & Salomon S. Barney \\
\hline Maturidade & Maior que um ano & $\begin{array}{c}\text { Maior ou igual a } \\
\text { um ano }\end{array}$ & $\begin{array}{c}\text { Maior ou igual a } \\
\text { um ano }\end{array}$ & $\begin{array}{c}\text { Maior ou igual a um } \\
\text { ano }\end{array}$ \\
\hline Emissões Excluídas & $\begin{array}{c}\text { Treasury } 1,5 \%, \\
\text { data de } 1 / 4 \text { a } 1 / 10 \\
\text { entre } 1951 \text { a } 1979\end{array}$ & $\begin{array}{l}\text { Qualquer emissão } \\
\text { com notadamente } \\
\text { valor ao par menor } \\
\text { que } 100 \text { milhões }\end{array}$ & $\begin{array}{l}\text { Qualquer emissão } \\
\text { com notadamente } \\
\text { valor ao par menor } \\
\text { que } 10 \text { milhões e } \\
\text { flower bonds }\end{array}$ & $\begin{array}{l}\text { Qualquer emissão com } \\
\text { notadamente valor ao } \\
\text { par menor que } 25 \\
\text { milhões e flower bonds }\end{array}$ \\
\hline Participaçao & $\begin{array}{l}\text { Valor de Mercado } \\
\text { e valores iguais }\end{array}$ & Valor de Mercado & Valor de mercado & Valor de mercado \\
\hline Preço & $\begin{array}{l}\text { Preços de } \\
\text { Oferta:The US } \\
\text { Treasury Boletin } \\
\text { and The Wall } \\
\text { Street Journal e } \\
\text { cotações FRB }\end{array}$ & preço de Mercado & $\begin{array}{l}\text { Bid-side e preço de } \\
\text { mercado }\end{array}$ & $\begin{array}{l}\text { Bid-side e preços de } \\
\text { mercado }\end{array}$ \\
\hline $\begin{array}{l}\text { Reinvestimento dos } \\
\text { Fluxos de Caixa }\end{array}$ & $\begin{array}{l}\text { Pre-1989 yield } \\
\text { iniciando } \\
\text { mensalmente; } \\
\text { desde } 1989 \text { em } \\
\text { bond específico }\end{array}$ & Nenhum & $\begin{array}{c}\text { Uma emissão } \\
\text { específica quando } \\
\text { avaliada } \\
\text { diariamente o } \\
\text { preço }\end{array}$ & $\begin{array}{l}\text { Na média diária de um } \\
\text { mês T-bills para } \\
\text { pagamentos mensais }\end{array}$ \\
\hline $\begin{array}{l}\text { Data Inicial para } \\
\text { dados mensais }\end{array}$ & $\mathrm{jan} / 50$ & $\mathrm{jan} / 73$ & $\mathrm{jan} / 78$ & $\mathrm{jan} / 80$ \\
\hline $\begin{array}{c}\text { Dados } \\
\text { Acompanhados } \\
\text { Diariamente }\end{array}$ & Sim & Sim & Sim & Sim \\
\hline
\end{tabular}

Quadro 1 - Metodologia RTI - Adaptado de Reilly, Wright e Chan(2000, p. 84)

Como índice do mercado de ações, os autores calcularam a taxa de retorno do índice S\&P 500, da série da Ibbotson Associates. Os autores então calcularam a volatilidade das duas classes de ativos e como medidas de volatilidade usaram:

1) A mudança desvio padrão das taxas de retorno mensais para o período de 12 meses do ano calendário; 
2) O desvio padrão discreto, não sobrepondo, o período de tempo de 12 meses do ano calendário.

A primeira medida de volatilidade fornece uma visão dinâmica das mudanças de volatilidade no ambiente do período de 50 anos e demonstra uma grande e rápida mudança na volatilidade do mercado de bonds. A segunda medida permite testar uma mudança significante sobre o tempo, na base de ano após ano e durante período de tempo alternativo.

Os resultados que os autores encontraram estão apresentados na Tabela 1, em que os anos de altas volatilidades estão expostos em ordem decrescente de volatilidade para as duas classes de ativos, e em ordem crescente de volatilidade os anos que apresentaram menores volatilidades.

Tabela 1: Resumo dos Índices Estatístico para Mercados de Bonds e Ações: Desvio Padrão Anual - 1950 - 1999 (EUA)

\begin{tabular}{|c|c|c|c|}
\hline \multicolumn{4}{|c|}{ Altas Volatilidades/Ano } \\
\hline & rcado de Bonds & & arcado de Ações \\
\hline Ano & $\begin{array}{c}\text { Desvio Padrão do } \\
\text { Retorno } \\
\end{array}$ & Ano & $\begin{array}{l}\text { Desvio Padrão do } \\
\text { Retorno }\end{array}$ \\
\hline 1980 & $\begin{array}{r}3,8809 \\
\end{array}$ & 1987 & 8,8049 \\
\hline 1981 & 3,1320 & 1974 & 6,9077 \\
\hline 1986 & 2,1280 & 1998 & 6,2054 \\
\hline 1979 & 1,9207 & 1970 & 5,8566 \\
\hline 1982 & 1,8001 & 1962 & 5,7990 \\
\hline 1984 & 1,7816 & 1982 & 5,5244 \\
\hline 1987 & 1,7029 & 1990 & 5,3086 \\
\hline 1985 & 1,6552 & 1980 & 5,2856 \\
\hline 1971 & 1,6403 & 1986 & 5,1776 \\
\hline 1970 & 1,6397 & 1975 & 5,1633 \\
\hline
\end{tabular}

\begin{tabular}{|c|c|c|c|}
\hline \multicolumn{4}{|c|}{ Baixas Volatilidades/Ano } \\
\hline \multicolumn{2}{|c|}{ Mercado de Bonds } & \multicolumn{2}{|c|}{ Mercado de Ações } \\
\hline Ano & $\begin{array}{c}\text { Desvio Padrão do } \\
\text { Retorno } \\
\end{array}$ & Ano & $\begin{array}{c}\text { Desvio Padrão do } \\
\text { Retorno }\end{array}$ \\
\hline 1963 & 0,1218 & 1964 & 1,1607 \\
\hline 1950 & 0,1571 & 1995 & 1,4965 \\
\hline 1964 & 0,2252 & 1993 & 1,7656 \\
\hline 1965 & 0,4099 & 1958 & 1,8097 \\
\hline 1952 & 0,4188 & 1972 & 1,9153 \\
\hline 1961 & 0,4508 & 1992 & 2,1272 \\
\hline 1962 & 0,4873 & 1959 & 2,3094 \\
\hline 1951 & 0,5104 & 1965 & 2,4661 \\
\hline 1955 & 0,5480 & 1961 & 2,5763 \\
\hline 1954 & 0,5820 & 1953 & 2,6988 \\
\hline
\end{tabular}

Fonte: Adaptado de Reilly, Wright e Chan(2000, p. 86)

Os resultados encontrados pelos autores Reilly, Wright e Chan (2000) no mercado dos EUA, sugerem que os picos de volatilidades dos dois mercados ocorreram em períodos diferentes. Nos gráficos expostos no trabalho dos autores em que mostram a movimentação dos desvios padrão ao longo dos 50 anos, calculados pela segunda medida de volatilidade, observa-se que os maiores picos de volatilidade do mercado de bonds dos EUA ocorreram entre 1970 e 1972 
e entre 1980 e 1982 e para o mercado de ações, os maiores picos ocorreram entre 1974 e 1975 e entre 1987 e 1988.

Tabela 2: Relação dos Desvios padrão - Mercado de Bonds Mercado de Ações (EUA)

\begin{tabular}{cccc}
\hline \multicolumn{2}{c}{ Maiores Razões } & \multicolumn{2}{c}{ Menores Razões } \\
\hline \multicolumn{1}{c}{$\begin{array}{c}\text { Razão do Desvio } \\
\text { Padrão }\end{array}$} & Ano & $\begin{array}{c}\text { Razão do Desvio } \\
\text { Padrão }\end{array}$ \\
\hline 1981 & 0,8419 & 1963 & 0,0435 \\
\hline 1958 & 0,7485 & 1950 & 0,0504 \\
\hline 1980 & 0,7344 & 1962 & 0,0842 \\
\hline 1995 & 0,7125 & 1952 & 0,1284 \\
\hline 1992 & 0,6268 & 1978 & 0,1387 \\
\hline 1993 & 0,6065 & 1951 & 0,1444 \\
\hline 1988 & 0,5199 & 1955 & 0,1530 \\
\hline 1983 & 0,5076 & 1954 & 0,1560 \\
\hline 1979 & 0,4980 & 1965 & 0,1662 \\
\hline 1985 & 0,4714 & 1974 & 0,1683 \\
\hline \hline
\end{tabular}

Fonte: Adaptado de Reilly, Wright e Chan(2000, p. 86)

De acordo com os resultados da Tabela 2, concluiu-se que o relacionamento da volatilidade dos dois ativos não é estável ao longo do tempo e a linha de tendência aplicada à razão da volatilidade entre os mercados de bonds e ações, se mostrou positiva, o que implica dizer que, nos Estados Unidos, a volatilidade do mercado de bonds tem aumentado mais do que a volatilidade do mercado de ações. Os autores explicam que esses resultados levam a crer que o mercado de bonds e o mercado de ações estão marchando para "batidas" diferentes de volatilidades.

A análise de volatilidade dos bonds relativa à volatilidade das ações indicou, no estudo, que o relacionamento entre os dois mercados é muito instável; há geralmente pouca correlação entre a volatilidade das duas classes de ativos, e houve um maior aumento no risco dos bonds relativo ao risco das ações ordinárias. 
Em seguida, foi testada a possibilidade de que os resíduos contivessem uma estrutura heterocedástica do tipo $\mathrm{ARCH}$, também devido ao fato de muitas séries financeiras de retorno mostrarem fortes heterocedasticidades condicionais. O modelo $\mathrm{ARCH}(1,1)$ utilizado foi dado por:

$$
Y_{t}=\alpha+\beta Y_{t-1}+\varepsilon_{t}
$$

em que $Y_{t}$ é a série dos desvios padrão dos mercados de bonds e ações.

Os resultados do modelo $\mathrm{ARCH}(1,1)$ indicaram que o padrão de volatilidade do mercado de ações foi muito diferente do padrão de volatilidade do mercado de bonds. Enquanto que os resultados encontrados para o mercado de ações sugerem que a volatilidade do mercado de ações não depende do ano anterior, já que o parâmetro encontrado para o mercado de ações do coeficiente $\beta$ não foi estatisticamente significante $(0,0102)$. Resultado diferente do mercado de bonds, onde as séries se mostraram dependentes, com coeficiente estatisticamente significante $(0,5775)$

A série de volatilidade dos bonds, portanto, tem maiores autocorrelações e foi bem modelada pelo modelo $\mathrm{ARCH}(1,1)$, enquanto as propriedades das séries temporais da volatilidade para a série de ações não foram significantes.

Além disso, o modelo mostrou que a volatilidade do mercado de bonds possui um comportamento sistemático através do tempo, já a volatilidade do mercado de ações não mostra um comportamento previsível das séries temporais. 


\subsubsection{Os estudos de Young e Johnson na Europa (2002,2004 e 2005)}

Young e Johnson (2002, 2004 e 2005) replicaram a pesquisa realizada por Relilly, Wright e Chan (2000) em países europeus: Reino Unido, Suíça e Alemanha. O estudo realizado no Reino Unido utilizou-se de dados para construção da série temporal do mercado de bonds de 1957 de 2000, e do mercado de ações de 1970 a 2000, comparando, então, os dois mercados em um período de 30 anos.

No Reino Unido, as duas classes de ativos apresentaram picos diferentes em suas volatilidades. As maiores volatilidades do mercado de bonds estiveram presentes nos anos de 1979, 1975, 1986 e 1982, enquanto que os picos de volatilidade do mercado acionário se apresentaram em 1975 (único ano coincidente), 1987, 1974 e 1976. A média da volatilidade do mercado de ações no Reino Unido é aproximadamente duas vezes maior que a média da volatilidade do mercado de bonds.

O estudo realizado na Suíça compreende o período 1964 a 2003 para o mercado de bonds e de 1970 a 2003 para o mercado de ações, sendo este último o período de comparação da volatilidade dos dois mercados.

No mercado suíço, as maiores volatilidades também ocorreram em momentos diferentes. Enquanto no mercado de ações as maiores volatilidades se apresentaram em 1998, 1987, 1975 e 1990, no mercado de bonds, os picos estiveram presentes em 1992, 1981, 1990 (único ano coincidente) e 1980. A média da volatilidade do mercado de ações se mostrou quatro vezes maior que a média da volatilidade do mercado de bonds, na Suíça. 
Já a pesquisa realizada pelos autores na Alemanha engloba o período dos retornos dos bonds de 1957 a 2003, embora devido à disponibilidade dos dados do mercado acionário, a comparação da volatilidade dos dois mercados foi realizada de 1973 a 2003.

No estudo da volatilidade do mercado alemão em um período de 30 anos, Young e Johnson (2005) também observaram que os picos de volatilidades dos dois mercados foram diferentes, já que o mercado de bonds apresentou maiores volatilidades nos anos de 1980, 1981, 1990 e 1979 respectivamente, e o mercado de ações 2002, 1987, 1990 (também único ano coincidente) e 2001.

A média da volatilidade do mercado de ações é três vezes maior do que a média da volatilidade do mercado de bonds no estudo do mercado alemão, resultado semelhante ao encontrado por Reilly, Wright e Chan (2000) no mercado americano.

Tanto os autores Reilly, Wright e Chan (2000) quanto Young e Johnson (2002, 2004 e 2005) usaram apenas a média ponderada do período das séries dos desvios padrão do mercado de ações e bonds para sugerirem suas conclusões do quanto um mercado foi mais volátil na média que o outro. Nenhum dos autores utilizou testes de diferenças de médias para tais conclusões.

Em nenhum dos estudos realizados anteriormente, seja no mercado americano, seja nos países europeus estudados, as volatilidades dos dois mercados apresentaram, por mais de um momento, picos coincidentes de volatilidade. Esse foi o argumento que sugeriu a construção da primeira hipótese deste trabalho. Também em nenhum dos estudos a volatilidade dos mercados manteve uma relação estável ao longo do período de análise, o que permitiu a construção da terceira hipótese deste estudo. 


\subsubsection{Estudos sobre a volatilidade do mercado de bonds}

Os bonds são definidos por Fabozzi (2000) como títulos de dívida ou instrumentos de dívida, que exigem do emissor, devedor ou tomador de empréstimo, o pagamento ao credor ou ao investidor da quantia tomada, acrescida de juros no decorrer de um período de tempo prédeterminado e representam os títulos do mercado de renda fixa.

Um princípio fundamental de um bond é que seu preço varia inversamente a uma variação do retorno exigido (FABOZZI, 2000, p. 77). De acordo com a afirmação de autor, uma das medidas que pode variar o preço dos bonds ao longo do tempo é uma variação nas taxas de juros praticadas pelo mercado.

Segundo Reilly, Wright e Chan (2000), o significante aumento na volatilidade das taxas de retorno durante o final dos anos oitenta e início dos anos noventa foi o desenvolvimento de muitos dos instrumentos derivados de bonds e técnicas de gerenciamento dos portfólios de bonds.

Fabozzi (2003) pontua que existem duas características de um bond livre de opções que determinam sua volatilidade: o cupom e o prazo até o resgate. Cupom são os pagamentos periódicos de juros feitos ao investidor, e prazo de resgate, a data em que será realizado o pagamento do principal.

É certo que uma maior volatilidade no mercado de bonds eleva o risco do ativo (Longstaff e Swartz, 1993), pois de acordo com Alexander (2005), mesmo se tendo um bom histórico do preço de um ativo, não é possível determinar exatamente como será o comportamento deste no futuro.

Reilly, Wright e Chan (2000) argumentam que pouco ainda foi estudado sobre a volatilidade do mercado de bonds, e que antes dos anos oitenta havia muito pouco ou quase 
nenhuma análise detalhada sobre o assunto, mas os autores citam dois estudos anteriores sobre a volatilidade do mercado de bonds nos Estados Unidos, sendo o primeiro um artigo de Coleman, Fisher e Ibottoson (1993), extraído de um capítulo do livro dos mesmos, de 1989:

[...]in which they examine the volatility of yields during the period 1926-1988. These results indicate a consistent increase in volatility over the four decades from 1950 through 1987, with the highest volatility during period $1980-1987$.

E o segundo, um estudo de Kuberek (1992) apud Reilly, Wright e Chan (2000), em que foi desenvolvido um modelo para prever a volatilidade do mercado de bonds e analisar as mudanças nesta volatilidade:

The analysis confirms the CFI contention that the level of rates has a significant effect on yield volatility, because the best predictive model implies that volatility is proportional to the level of interest rates. Kuberek also determines that a substantial amount of the change in volatility is random, and one could predict this random component using an $\mathrm{ARCH}$ model. Notably, he also finds that volatility increased during the 1980s and identifies three periods of extremely high bond market volatility: 19571961, 1967-1971 and 1977-1981.

Em sua tese de doutorado sobre os determinantes da volatilidade dos títulos soberanos dos países Argentina, México, Rússia e Brasil, de 01/01/1994 a 31/12/2002, Marçal (2004) concluiu que os choques negativos têm efeitos diferenciados na volatilidade desses títulos, gerando mais impactos negativos do que notícias relativamente boas. Ainda constatou, por exemplo, que existe uma espécie de "contágio" das crises financeiras nos mercados, ou seja, seus resultados mostraram que a crise do México, ocorrida no período estudado, e sua respectiva volatilidade “contaminou” os demais países.

Marçal (2004) utilizou, para realização do estudo, o EMBI (Emerging Markets Bonds Index), calculado a partir de uma carteira de títulos soberanos de determinado país, índices construídos por J.P. Morgan (1995). 
Goeu e Marquering (2004), estudaram a interação intertemporal dos retornos dos mercados das ações e dos bonds no mercado americano, no período de janeiro de 1982 a agosto de 2001. Os resultados do estudo indicaram que más notícias nos mercados de ações e de bonds são tipicamente seguidas por uma maior covariância condicional, do que boas notícias. As covariâncias entre os retornos das ações e dos bonds tendem a ser relativamente menores depois de más notícias no mercado de ações e de boas notícias no mercado de bonds.

\subsubsection{Estudos sobre a volatilidade do mercado de ações}

Em relação à volatilidade do mercado de ações, mais estudos exploraram o assunto comparativamente ao mercado de bonds, como os estudos de Fisher e Lorie (1970), Officer (1973), Schwert (1989, 1990), Jones e Wilson (1989), Ceretta e Costa (1999), Santos (2000), Mota e Fernandes (2004), por exemplo. E o estudo de Ramalho, Securato e Silveira (2004), que compara o retorno dos mercados de renda variável e renda fixa num período de 18 anos.

O estudo de Fisher e Lorie (1970) considerou todas as ações da NYSE e examinou mudanças na variância e na distribuição dos retornos ao longo do período estudado. Essa foi a primeira análise da variação do mercado de ações sobre o tempo. O desvio padrão e o coeficiente de variação, medidos pelos autores, indicaram que os retornos de mercado durante o período de 1946-1965 foram significativamente menos voláteis que durante 1926-1945, indicando que a maior volatilidade ocorreu, então, próximo aos anos 30 e seguiu após o crack da Bolsa. Um outro pico de volatilidade do mercado de ações ocorreu no período da Segunda Guerra Mundial. 
Officer (1973) estudou o período de 1897 a 1969 e conclui que o declínio na variabilidade do mercado de ações notada por Fisher e Lorie (1970) representa apenas um retorno ao nível normal da variabilidade antes da Grande Depressão de 1930, isto é, a variação do retorno das ações antes de 1930 foi similar à variação depois de 1942, novamente confirmando os períodos que antecederam o crack de 1929, e durante a segunda guerra.

Schwert (1989) analisou a relação da volatilidade das ações (no período de 1857 a 1987) e a comparou à volatilidade de variáveis macroeconômicas e de outros ativos do mercado financeiro. Alternativamente, a volatilidade do retorno das ações é maior em períodos de recessão econômica, porém mudanças na margem exigida e negociada nos mercados futuros e opções não têm efeito no mercado de ações.

A pesquisa de Schwert (1990) foi mais além em relação ao tempo e examinou a volatilidade das ações listadas na NYSE, no período de 1802 a 1989 e se ateve a responder duas questões:

1. O que tem acontecido na volatilidade do preço das ações ao longo do tempo?

2. Quais fatores econômicos são relatados para significantes mudanças na volatilidade do preço das ações ao longo do tempo?

Esse artigo examina e evidencia a volatilidade das ações diante da perspectiva de um debate de 1987, ano em que ocorreu o crash do mercado de ações, e 1989, quando houve um declínio nos preços do mercado de ações.

A lista de variações diárias nos percentuais de retorno durante o período de 105 anos (de 1885 a 1989), observado pelo autor, indica que embora o aumento por dia declinasse em 19 de outubro de 1987, quase todos os outros grandes declínios foram de 1929 a 1939, e a grande repercussão de 1987, seguida do crash, foi somente o $7^{\circ}$ da lista. De novo, o grande aumento mensal ocorreu durante os anos trinta. 
Os autores Jones e Wilson (1989) examinaram diariamente o preço das ações de março de 1885 a outubro de 1989 para determinar se os preços das ações nos anos 80 foram mais voláteis, seguido do crash de 1987. Eles concluíram que os anos 30 tiveram um período de maior volatilidade e verificaram também que a posição relativa dos anos 80 , omparada a todo o período, depende da medida de volatilidade empregada e do intervalo usado (dias ou meses).

Ceretta e Costa (1999) verificaram a volatilidade do mercado acionário de países da América Latina, os chamados países emergentes, e constataram que os eventos negativos ocorridos na economia desses países, por exemplo, choques econômicos, crises políticas ou especulação financeira excessiva, característica de países emergentes, impactam mais à volatilidade do mercado acionário do que eventos positivos.

No estudo sobre a volatilidade e a informação obtida pelos operadores nas negociações das ações, Santos (2000) analisa a série de retornos diários do Ibovespa e de 28 ações isoladas cuja ponderação responde por mais de $90 \%$ deste índice, no período de $1^{\circ}$ de julho de 1994 a 30 de junho de 1999 em três períodos distintos:

- Implantação do Plano Real (de 01/07/1994 a 30/06/1995);

- Crise da Ásia (01/07/1995 a 30/06/1997);

- Crise da Rússia e o abandono, pelo Brasil, do regime de bandas cambiais (01/07/97 a 30/07/99).

$\mathrm{O}$ autor constatou que os retornos apresentaram alta volatilidade nos primeiro e últimos períodos e volatilidade moderada no período de 1995 a 1997.

Mota e Fernandes (2004) analisaram a série de retorno diários do IBOVESPA de 01/08/1994 a 24/10/2001, e constataram exemplo do estudo de Santos (2000), que o período que apresentou alta volatilidade foi o de dezembro de 1994, provavelmente associado à crise do 
México. Após outubro de 1997, depois de um longo período de baixa volatilidade, ao final da crise da Ásia, a volatilidade novamente se eleva e em agosto de 1998, período da moratória da Rússia, acontece outro aumento da volatilidade.

Ramalho, Securato e Silveira (2004) compararam os retornos médios do IBOVESPA e do CDI, no período de 1986 a 2004 (separadas dentro do período em oito janelas de tempo). O objetivo do artigo era obter informações a respeito do comportamento do mercado acionário brasileiro, quando comparado à taxa básica de juros, representado pelo CDI.

Os autores esperavam que, dentro do período estudado, os retornos médios do IBOVESPA fossem para todas as janelas de tempo superiores aos retornos médios do CDI, entretanto concluíram que, em apenas quatro, das oito janelas de tempo analisadas, o IBOVESPA se mostrou superior e mesmo assim, com uma diferença relativamente baixa.

Em outras palavras, "os desempenhos do IBOVESPA, quando superiores aos do CDI, apresentaram retornos pouco superiores para compensar o risco adicional assumido pelo investimento em um ativo de renda variável” (Ramalho et al, 2004, p. 7).

Como visto nos trabalhos acima citados, de Fisher e Lorie (1970), Officer (1973), Schwert (1990) e Jones e Wilson (1989), o mercado dos EUA apresentou maior volatilidade no mercado acionário próximo dos anos trinta, com o crack da bolsa, causado por uma queda do consumo interno e conseqüente superprodução. No Brasil, de acordo com Ceretta e Costa (1999), a volatilidade do mercado acionário foi mais atingida por fatores como choques econômicos, e para Santos (2000) e Mota e Fernandes (2004) os períodos de maior pico de volatilidade coincidiram com a implantação do Plano Real e a Crise do México (em dezembro de 1994), e com o início da Crise da Rússia e fim do regime de bandas cambiais brasileiro. 


\section{METODOLOGIA DA PESQUISA}

O plano de pesquisa deste estudo apresenta caráter descritivo e documental, com a finalidade de analisar e descrever as mudanças na volatilidade dos dois ativos, baseada em informações existentes e disponíveis no mercado. Além disso, o emprego da quantificação, tanto na coleta de dados quanto no tratamento dos dados por meios estatísticos, classifica o trabalho em quantitativo (RICHARDSON, 1999).

Para este estudo foram utilizados dois indicadores do mercado de renda fixa, o CDI (Certificado de Depósito Interfinanceiro), que é o título que lastreia as operações do mercado interfinanceiro, e o IRF-M (Índice de Renda Fixa do Mercado), um índice criado em 2000 pela ANDIMA em parceria com a BM\&F, que calcula a evolução do valor, a preços de mercado, de uma carteira de Letras do Tesouro Nacional. O primeiro é um parâmetro para o mercado de títulos de renda fixa pós-fixado, o segundo para o mercado de títulos de renda-fixa pré-fixado.

Com o objetivo de comparar a volatilidade do mercado de renda fixa com a volatilidade do mercado de ações, foi utilizado como indicador de volatilidade para este último a variação do IBOVESPA, no período 1986-2006. A delimitação temporal desta pesquisa deve-se ao fato da indisponibilidade de dados referentes ao CDI, antes de março de 1986.

Este trabalho replicou a metodologia utilizada pelos autores, Reilly, Wright e Chan (2000), que produziram o estudo da volatilidade dos dois ativos (bonds e ações) para o mercado dos EUA, em um período de cinqüenta anos. Young e Johnson $(2002,2004,2005)$ replicaram a pesquisa dos autores supracitados, em países europeus: Reino Unido, Suíça e Alemanha. Os autores analisaram as mudanças na volatilidade do mercado de bonds e do mercado de ações para estes países em diferentes períodos de tempo. No Reino Unido a série temporal utilizada 
contava com quarenta e três anos, na Suíça, trinta e nove anos e na Alemanha quarenta e seis anos.

\subsection{Os índices - CDI, IRF-M e IBOVESPA}

Durante vários anos, o CDI foi um dos únicos bechmark para o mercado de renda fixa brasileiro. Devido principalmente a instabilidade econômica anterior ao Plano Real, os índices que surgiam no Brasil estavam mais relacionados a explicar os fenômenos da aceleração inflacionária. De acordo com a BM\&F (2006), a taxa acumulada de Depósitos Interfinanceiros de um dia, CDI over, era então utilizada como parâmetro para qualquer aplicação em renda fixa.

Segundo Assaf Neto (2005, p. 197), os CDIs (Certificado de Depósito Interfinanceiro) são títulos que lastreiam as operações do mercado interfinanceiro. De acordo com a definição do Dicionário de Finanças da BOVESPA ${ }^{4}$, o CDI é um "título emitido por instituições financeiras com o objetivo de captar recursos de outras instituições financeiras; no jargão de mercado se diz da taxa de juros que remunera tais depósitos".

Assim sendo, o CDI, por ser um título pós-fixado, estava menos sujeito ao risco sistemático de mercado do que os títulos pré-fixados, pois sua taxa acompanha a taxa de juros nominal básica da economia. Já investimentos em títulos pré-fixados, principalmente em títulos de longo prazo, em períodos de grande instabilidade econômica, poderiam acarretar significativas perdas de recursos aos investidores.

\footnotetext{
${ }^{4}$ Disponível no site www.bovespa.com.br. Acesso em 15/12/2006.
} 
Após a estabilização da economia e queda da taxa nominal de juros, foram restabelecidos os mercados de títulos pré-fixados de prazos mais longos. Segundo a BM\&F (2006, p.2) "os derivativos das taxas de juros que também ampliaram significativamente os prazos das operações dos contratos de taxas pré-fixadas, levaram à discussão de questões estruturais relacionados ao mercado." Mesmo assim, faltava no mercado de renda fixa um índice que fosse capaz de se tornar benchmark para este mercado, no sentido de se tentar substituir o CDI desta função.

A ANDIMA e a BM\&F criaram então, no ano de 2000, o Índice de Renda Fixa do Mercado (IRF-M). O cálculo do IRF-M, segundo a BM\&F (2006), mede a evolução do valor, a preços de mercado, de uma carteira de Letras do Tesouro Nacional, de valor inicial de R\$ $1.000,00$, em que os montantes aplicados a cada maturidade (vencimento) guardam a mesma relação com o estoque destes papéis em poder do público. Dessa forma, a rentabilidade do índice é a variação do valor no período de tempo considerado, e o valor do índice é o valor de sua carteira teórica do dia respectivo.

Como indicador do mercado de renda fixa este estudo se utiliza desses dois índices. Em um primeiro momento, foi realizada a análise utilizando-se o CDI, como indicador do mercado de renda fixa para um período de vinte anos (1986-2006). Os dados foram coletados no banco de dados Economática ${ }^{\circledR}$ e o índice utilizado foi o CDI diário 252, que representa a taxa over anual. Segundo Assaf Neto (2003, p. 178), o cálculo da taxa over anual é processado com base em 252 dias úteis. Na série histórica desse índice encontram-se dados disponíveis desde março de 1986, data em que se inicia a análise deste trabalho. Para formação do período proposto, de vinte anos, foram considerados os dados até fevereiro de 2006.

Para realização da segunda análise, o IRF-M foi coletado junto ao site da BM\&F e sua série histórica se inicia em dezembro de 2000, de acordo com os dados disponíveis, finalizando em dezembro de 2006. Utilizou-se para a base dos cálculos, o preço de fechamento diário deste 
índice.

Portanto, para o mercado de renda fixa foram realizados dois estudos, um que contempla o CDI como benchmark para o mercado de renda fixa brasileiro, em um período de vinte anos, e outro para um período de seis anos, em que se utiliza o IRF-M para a mesma finalidade.

Como benchmark para o mercado de renda variável, o presente trabalho utilizou-se do IBOVESPA. Esse índice, conforme conceituado pela BOVESPA (2006), é o valor atual, em moeda corrente, de uma carteira teórica de ações constituída inicialmente em 02/01/1968 (valorbase: 100 pontos), a partir de uma aplicação hipotética. O IBOVESPA retrata não apenas as variações dos preços das ações, mas, por sua metodologia considerar o impacto da distribuição de proventos, também é considerado um indicador que avalia o retorno total de suas ações componentes. A série temporal histórica do IBOVESPA foi extraída da base de dados Economática $^{\circledR}$ e a utilizada tem início em março de 2006, de modo que se permita a comparação temporal com o CDI.

Primeiramente será realizada a comparação da volatilidade do CDI com o IBOVESPA, para o período de vinte anos já mencionado, em seguida, serão realizados os mesmos testes para efeito de comparação do IRF-M com o IBOVESPA, para um período de seis anos. O objetivo das duas análises é verificar se os padrões intertemporais de volatilidade dos dois indicadores de renda fixa são muito divergentes, quando comparados a um indicador de renda variável, já que o CDI representa o mercado de títulos pós-fixados, e o IRF-M, o de pré-fixados.

Todas as hipóteses deste estudo (Hipóteses 1, 2 e 3) serão testadas com base na comparação do CDI e IBOVESPA, por compreender um período de tempo superior a comparação do IRF-M com o IBOVESPA. 


\subsection{Medidas de Retorno e de Volatilidade}

Para todos os índices foram calculados os retornos mensais da série histórica estudada. Para compor a taxa de retorno mensal do CDI foram utilizadas as taxas diárias do CDI over anual, que foram transformadas em taxas diárias por dia útil e então acumuladas para cada mês. O cálculo que descreve o procedimento adotado então:

$$
C D I_{d u}=\left[\left(1+C D I_{o v e r}\right)^{\frac{1}{252}}-1\right]
$$

em que $C D I_{d u}$ representa a taxa diária por dia útil, e $C D I_{\text {over }}$ a taxa over anual. Após conhecer as taxas diárias por dia útil, as mesmas foram acumuladas de acordo com o número apresentado de dias úteis em cada mês, para os meses correspondente dentro da amostra. Assim sendo, a taxa de retorno mensal do CDI, pode ser expressa como:

$$
C D I_{\text {mês }}=\left[\left(1+C D I_{d u 1}\right) \times\left(1+C D I_{d u 2}\right) \times\left(1+C D I_{d u 3}\right) \times \ldots \times\left(1+C D I_{d u N}\right)-1\right] \text {, }
$$

sendo $1,2,3$ e $N$ representam os dias úteis dentro de cada mês.

Como forma de se calcular o retorno mensal dos índices IBOVESPA e IRF-M, foram utilizados os dados de fechamento de cada índice. No caso do IBOVESPA, foram utilizados os pontos de fechamento diário, e do IRF-M o preço de fechamento da carteira também diário. Assim sendo, os retornos mensais dos dois títulos foram calculados da seguinte forma:

$$
i_{j, n}=\ln V P_{j, n}-\ln V P_{j, n-1}
$$

em que $i_{j, n}$ é o retorno diário do índice, $\ln V P_{j, n}$ é o logaritmo neperiano do valor de fechamento do dia $n$, e $\ln V P_{j, n-1}$ é o logaritmo neperiano do valor de fechamento do dia anterior.

Segundo Securato (2005), quando falamos em risco nos referimos a uma medida quantitativa: o desvio padrão. E o desvio padrão dos retornos calculados por meio da diferença 
dos logaritmos neperiano representa a volatilidade de uma série.

Como medidas de volatilidade foram utilizadas as duas medidas usadas pelos autores Reilly, Wright e Chan (2000):

1) O desvio padrão discreto das séries de retornos, calculado pelos meses "fechados", ou seja, do primeiro mês do ano ao último mês do ano (de janeiro a dezembro de todos os anos, com exceção de 1986, em que a amostra se inicia em março, portanto de março a dezembro);

2) Os desvios padrão contínuos, calculados mês a mês, ou seja, do primeiro mês até os 12 meses seguintes, depois, do segundo mês até os próximos doze meses e assim sucessivamente (de março/86 a fevereiro/87, depois de abril/86 a março/87 e assim sucessivamente).

O desvio padrão anual dos retornos mensais então é dado por:

$$
\sigma=\sqrt{\frac{\sum_{i-1}^{n}\left(Y_{i}-\bar{Y}\right)^{2}}{n-1}}
$$

em que $\mathrm{Y}_{\mathrm{i}}$ representa o retorno mensal do índice, $\bar{Y}$ a média destes retornos e $\mathrm{n}$ o número de observações da amostra.

Como forma de se certificar da metodologia utilizada pelos autores Reilly, Wright e Chan (2000), foram coletados dados dos retornos mensais da S\&P500 no período de janeiro de 1990 a dezembro de 2000. Os resultados obtidos utilizando a metodologia apresentada acima para o cálculo do retorno e dos desvios padrão foram os mesmos apresentados pelos autores, conforme demonstrado na Figura 12 (a) e (b):

\footnotetext{
${ }^{5}$ Os retornos mensais da S\&P500 foram coletados junto ao site www.standardandpoors.com. Acesso em 15/12/2006.
} 
(a)

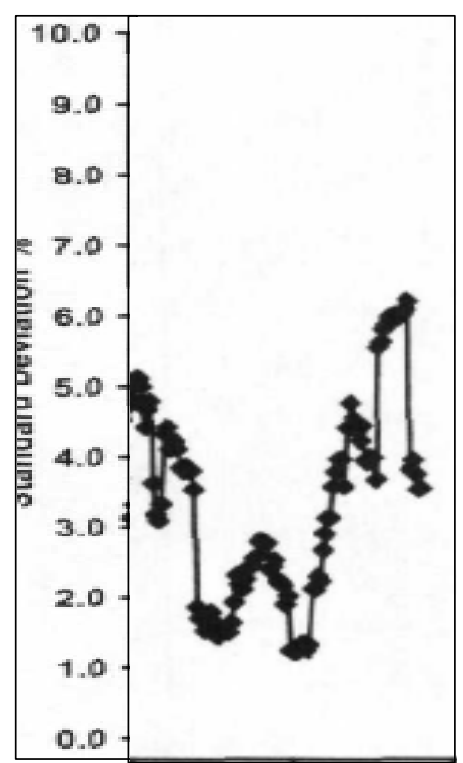

(b)

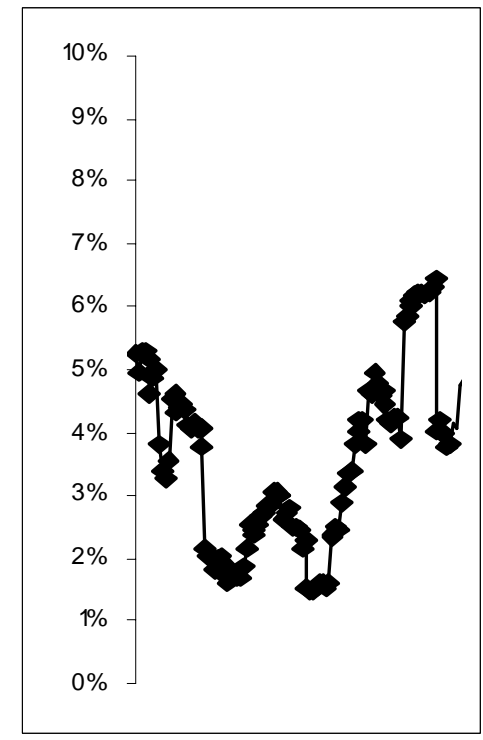

Figura 12: (a) Volatilidade do Índice S\&P500 de 1990 a 2000 calculada por Reilly, Wright e Chan (2000) (b) Volatilidade do Índice S\&P500 de 1990 a 2000 calculada pela autora

\subsection{Volatilidade do mercado de renda variável versus volatilidade do mercado de renda} fixa

Para comparação da volatilidade do mercado de renda fixa e do mercado de renda variável, foram calculados os desvios padrão dos retornos mensais dos indicadores dos dois mercados. Primeiramente, as séries consideradas foram os desvios padrão do CDI e do IBOVESPA para um período de vinte anos, de março de 1986 a fevereiro de 2006. Em um segundo momento do estudo, foi considerada a série de seis anos do IRF-M, de dezembro de 2000 a dezembro de 2006, a qual também será comparada ao IBOVESPA.

Dados os resultados encontrados no primeiro estudo, a série foi dividida entre as dez 
maiores e as menores volatilidades anuais e verificado se os dois mercados contemplam os picos de volatilidade nos mesmos períodos. Assim, os resultados foram explicados de acordo com a oscilação das variáveis macroeconômicas e do plano econômico em que tais picos se encontram.

Foi aplicado o Teste de Hipótese para Diferença entre duas Médias (Stock e Watson, 2004) às variáveis, o qual testa a hipótese nula de que as duas séries possuem médias estatisticamente iguais. A hipótese nula é expressa por $\mathrm{H}_{0}: \mu 1=\mu 2$ e a hipótese alternativa por $\mathrm{H}_{1}: \mu 1 \neq \mu 2$. No teste temos $\mu 1=\mu 2$, portanto, $\mu 1-\mu 2=0$. A estatística de teste foi calculada como segue:

$$
t=\frac{\bar{X}_{1}-\bar{X}_{2}-\left(\mu_{1}-\mu_{2}\right)}{\sqrt{\frac{\sigma_{1}^{2}}{n_{1}}+\sqrt{\frac{\sigma_{2}^{2}}{n_{2}}}}},
$$

em que $\bar{X}$ representa as médias das séries dos desvios padrão dos retornos das variáveis em estudo, CDI, IBOVESPA ou IRF-M, e o denominador da equação é definido como o erro padrão ou erro amostral. De acordo com Stock e Watson (2004, p. 51), "para conduzir um teste com um nível de significância fixado, simplesmente calcule a estatística t da equação acima e compare-a com o valor crítico apropriado". Em seguida, foi realizado o teste de Intervalos de Confiança para a Diferença entre duas Médias a fim de constatar se a diferença de média encontrada entre as variáveis se encontrava dentro do intervalo, de acordo com o nível de significância $(\alpha)$.

Para o segundo estudo, ou seja, a comparação do IRF-M com o IBOVESPA, as volatilidades não foram separadas como maiores ou menores, apenas foram dispostas em ordem crescente de volatilidade para verificação da coincidência dos maiores e menores picos, dado que a série histórica é pequena. O Teste de Hipótese para Diferença entre duas Médias foi calculado para verificar o quanto uma série na média foi mais volátil que a outra. 
Para análise do relacionamento da volatilidade dos dois mercados, foi realizada a razão dos desvios padrão das séries estudadas, as quais foram calculadas da seguinte forma nas duas partes do estudo:

$$
r=\frac{\sigma_{r f}}{\sigma_{r v}}
$$

sendo $\boldsymbol{\sigma}_{r f}$ o desvio padrão dos retornos do mercado de renda fixa e $\boldsymbol{\sigma}_{r v}$ o desvio padrão dos retornos do mercado de renda variável.

Uma outra medida de volatilidade relativa é o beta $(\beta)$ para a regressão das taxas de retornos mensais do mercado de renda fixa em função do mercado de renda variável, que explica o risco sistemático da relação renda fixa e renda variável. Para esses modelos de regressões foram usadas 12 observações mensais, ou seja, aplicou-se a mesma mudança na volatilidade usada nos cálculos dos desvios padrão. Como o $\beta$ é determinado por:

$$
\beta=\frac{C O V_{r f, r v}}{\sigma_{r v}^{2}}
$$

ou seja, a covariância dos retornos do mercado de renda fixa e variável, em relação à variância do mercado de renda variável, então um importante fator que poderia ajudar a explicar o risco sistemático entre os mercados, é a covariância entre os dois ativos. Mas como a covariância é determinada por:

$$
C O V_{r f, r v}=C O R R_{r f, r v} \times \sigma_{r f} \times \sigma_{r f},
$$

então, o principal fator impactante na covariância e no beta é a correlação entre os mercados de renda fixa e renda variável. A correlação dos dois mercados foi calculada, observando sua mudança ao longo do tempo em observações de 12 meses.

Também foi utilizado o processo GARCH(1,1) às séries do CDI, IBOVESPA e do IRF$\mathrm{M}$, que equivale, como já mencionado no capítulo 2, a um modelo do tipo $\mathrm{ARCH}(p)$, porém, para 
melhor adequação a este tipo de modelo à série do CDI foi descontada a inflação (representada aqui pelo IPC) trabalhando, dessa forma, com o CDI Real, e os desvios padrão anuais foram recalculados para estes novos dados e comparados ao modelo.

Para o IRF-M e o IBOVESPA foram calculados os retornos diários de ambos os índices (também encontrado pela diferença entre os logaritmos), pois o modelo $\mathrm{GARCH}(1,1)$ converge melhor para dados diários (Alexander, 2005). Calculou-se então o desvio padrão mensal dos retornos das duas séries para comparação ao modelo $\operatorname{GARCH}(1,1)$. O teste realizado da hipótese nula, de que as séries temporais possuíam raízes unitárias, foi o teste ADF (Dickey-Fuller Aumentado).

O modelo GARCH(1,1), o teste ADF e demais testes correspondentes foram calculados no programa Eviews ${ }^{\circledR} 5.1$, os cálculos anteriores, dos desvios padrão, razão, correlação, beta e Teste de Diferença de Média foram realizados no programa MS Excel ${ }^{\circledR}$ (suplemento de estatística).

Para verificar se os resíduos do modelo possuíam autocorrelação, foi aplicado o Teste ARCH-LM disponível no aplicativo Eviews ${ }^{\circledR}$ 5.1. Esse teste é uma forma do teste do multiplicador de Lagrange, "e essa estatística se distribui assintoticamente como um chi quadrado com $p$ graus de liberdade" (ALEXANDER, 2005, p. 366).

Esse teste de autocorrelação baseia-se na comparação dos valores da estatística $n \times R^{2}$ (em que $n$ é o tamanho da amostra multiplicado pelo coeficiente de determinação $R^{2}$ ) com os valores críticos da estatística chi quadrado $\left(\chi^{2}\right)$. De acordo com Gujarati (2006), se o valor obtido de $\chi^{2}$ exceder o valor da estatística $n \times R^{2}$, rejeita-se a hipótese de autocorrelação dos resíduos, ou heterocedasticidade dos mesmos. 


\section{RESULTADOS}

\subsection{Volatilidade do Mercado de Renda Fixa - CDI}

A Figura 13 demonstra a volatilidade dos retornos mensais do mercado de renda fixa, representado pelo CDI, em um período de vinte anos, de dezembro de 1986 a fevereiro de 2006.

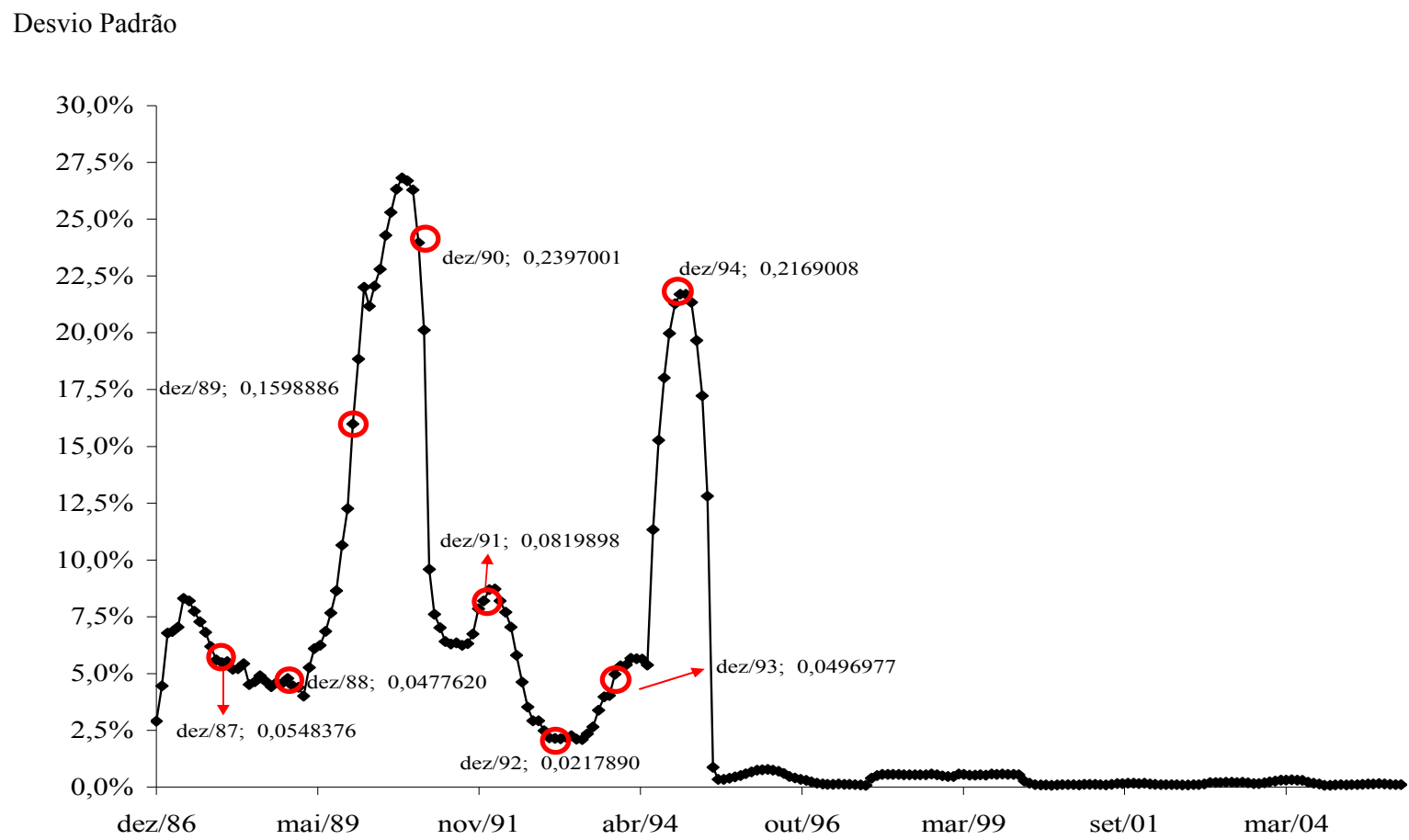

Figura 13: Desvio Padrão Anual dos Retornos Mensais - CDI de dez./86 a fev./06.

Os pontos em destaque na Figura 13 referem-se ao mês de dezembro de cada ano, dentre o período dez./1986 até dez./1994. Esses pontos correspondem à volatilidade do ano calendário, ou seja, aos períodos de janeiro a dezembro do respectivo ano, com exceção de 1986 conforme abordado anteriormente, já que a amostra se inicia em março. A série descrita pela Figura 13 evidencia que as mais altas volatilidades ocorreram anteriormente e no ano da implantação do Plano Real. Os picos de maior destaque aconteceram nos anos de 1989, 1990 e 1994. 
O ano de 1989, que apresenta o grande primeiro pico de volatilidade do mercado de renda fixa, além de ter sido eleitoral, com a primeira eleição direta para presidente da república depois de vinte e nove anos, compreende o período do Plano Verão, que visava, a exemplo dos anteriores, conter o processo de aceleração inflacionária por meio do congelamento de preços e da fixação da taxa de câmbio.

Esse grande aumento da volatilidade no mercado de renda fixa do ano de 1989 pode ser creditado ao aumento das taxas reais de juros na economia. Com a perda de confiança no governo, que aumentou seus juros financiados por aumento do endividamento, houve fuga de capital e de investimento nas operações de open market. Com a falta de credibilidade do governo em relação ao pagamento da dívida interna, o mercado de títulos públicos ficou desacreditado e os investidores buscaram outros tipos de ativos para alocarem em suas carteiras.

Já no ano seguinte, 1990, após uma queda nos primeiros três meses das taxas reais de juros, a mesma voltou a subir com a implantação do Plano Collor e da política econômica do bloqueio dos haveres financeiros (para diminuir fortemente a liquidez e com isso conter a inflação).

Quando Collor de Mello assumiu a presidência da república, a inflação atingia a casa dos 80\% mensais. Durante o ano de 1990, com a inflação estabilizada, a taxa real de juros cedeu, mas devido ao fracasso de outro plano econômico, a inflação voltou a subir rapidamente, o que pode ser a fonte da explicação de um novo aumento na volatilidade do CDI, por ser uma taxa nominal.

Nos anos de 1991 e 1992, o CDI apresentou baixas volatilidades e voltou a subir novamente em 1993, ano da articulação do Plano Real. Como, após a implantação do Plano Real, a volatilidade do mercado de renda fixa caiu abruptamente, a Figura 14 evidencia apenas o período pós-Plano Real, já que houve uma mudança considerável de escala. 
Na série que compreende o período de março de 1986 até a primeira metade de 1995, a variação da volatilidade situou-se entre $2 \%$ e $27 \%$. Já no período que compreende a segunda metade de 1995 até fevereiro de 2006, a volatilidade apresentou uma escala de, aproximadamente, $0,08 \%$ a $0,8 \%$, o que demandou a divisão do estudo da volatilidade do mercado de renda fixa, por meio do CDI, em dois períodos: de março de 1986 a maio de 1995 e de junho de 1995 a fevereiro de 2006.

A Figura 14 ilustra a volatilidade no período de meados de 1995 até fevereiro de 2006.

Desvio Padrão

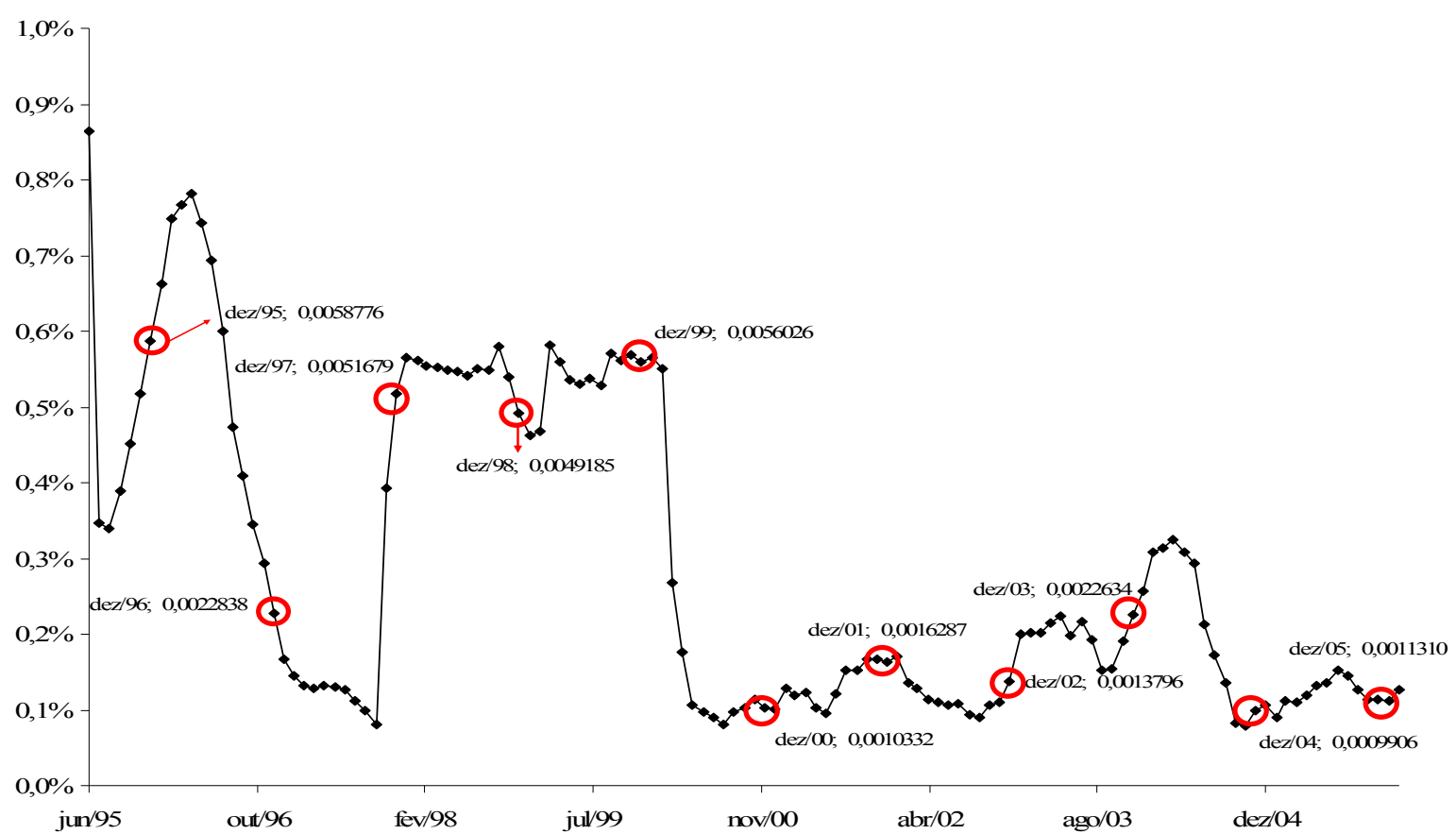

Figura 14: Desvio Padrão Anual dos Retornos Mensais - CDI de junho/1995 a fevereiro/2006.

No período de junho de 1995 a dezembro de 2005 a volatilidade do mercado de renda fixa variou de cerca de $0,1 \%$ a $0,8 \%$. A taxa básica de juros da economia que, em julho de 1994, estava em torno de $150 \%$ ao ano, baixou para menos de 50\% já no início de 1995 e permaneceu oscilando em torno desse número durante todo o ano. 
Mesmo com essa queda considerável da taxa de juros, em 1995, em virtude principalmente do controle da inflação, a taxa SELIC continuou declinando ao longo de 1996 (caiu de $35 \%$ ao ano para cerca de $25 \%$ ao ano), o que pode ter acarretado a queda na volatilidade do mercado de renda fixa no ano de 1996.

No segundo semestre de 1997, uma nova alta da taxa de juros elevou a volatilidade do mercado de renda fixa, que permaneceu em patamares em torno de $0,5 \%$ a $0,6 \%$. A taxa nominal de juros variou entre $30 \%$ a.a. e $40 \%$ a.a. até o primeiro semestre de 1999 , quando, então, cedeu e permaneceu até o terceiro trimestre de 2002 entre $15 \%$ a.a. e $20 \%$ a.a.

Em 2002 as variáveis macroeconômicas reagiram às especulações existentes no mercado e os preços dos ativos apresentaram alta, seguida da taxa de juros. Isso ocorreu principalmente devido às eleições presidenciais que, segundo as pesquisas, apontavam uma possível mudança de partido no governo, do PSDB para o PT, do então candidato Luis Ignácio Lula da Silva, após oito anos de mandato e um bem sucedido plano de estabilização da economia do governo FHC.

Tal cenário se estendeu ao primeiro ano de governo do presidente Lula, pois havia muita expectativa em relação ao futuro da economia. Essas incertezas presentes no mercado ajudam a explicar um leve aumento na volatilidade do mercado de renda fixa, que perdurou até meados de 2004, quando declina e se mantém em patamares mais uniformes até o final do ano de 2005.

\subsection{Volatilidade do Mercado de Renda Variável - IBOVESPA}

Assim como ocorreu com a volatilidade do mercado de renda fixa, a volatilidade do mercado de renda variável diminuiu consideravelmente após 1994, ano da implantação do Plano Real, representada na Figura 15 pelo desvio padrão dos retornos mensais do IBOVESPA. 


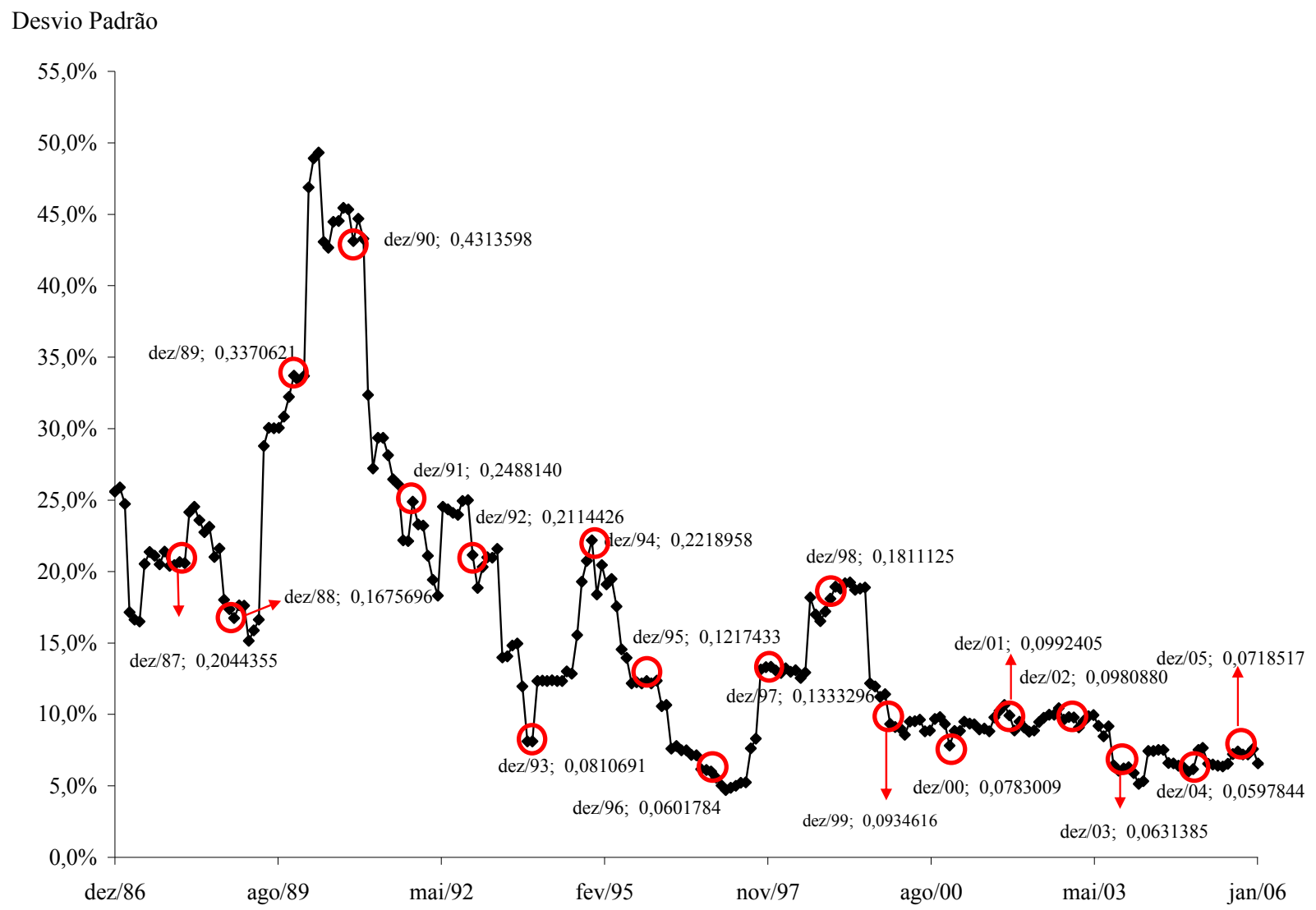

Figura 15: Desvio Padrão Anual dos Retornos Mensais - IBOVESPA - dez./06 a fev./06.

Os maiores picos de volatilidade do mercado de renda variável estão entre os anos de 1989 e 1991, período que compreende o final do Plano Verão, eleições presidenciais diretas e governo Collor.

Conforme já mencionado, esse foi o período em que a taxa de inflação bateu recordes e o país viveu instabilidade política e financeira, o que gerou incerteza no mercado e elevação da volatilidade. No período do Plano Verão, em 1989, com a perda de confiança no governo, que aumentou seus juros financiados por aumento do endividamento, houve queda nos investimentos das operações de open market, o que pode ter incentivado a "migração" dos investimentos ao mercado de renda variável. 
Após a posse de Fernando Collor, a volatilidade do mercado de ações diminuiu, mas voltou a subir em 1992, época da maior crise política enfrentada pelo governo, já que foi pedido o impeachment do presidente devido a denúncias de corrupção. Em 1993 houve o menor pico de volatilidade de todo o período anterior ao Plano Real, uma vez que nesse ano pouco variou o retorno mensal do índice IBOVESPA.

O ano de 1994 apresentou alta da volatilidade no mercado de ações, por ser o ano da implantação definitiva do Plano Real. Após esse ano, as maiores volatilidades do mercado acionário são encontradas nos anos de 1995, 1997, 1998 e 1999. Apesar de 1995 estar presente nesse conjunto de picos de volatilidade, observa-se uma queda considerável nos patamares de volatilidade após 1994, que se estende até 1996, com a economia mais estabilizada.

As altas volatilidades apresentadas nos anos de 1997 e 1998 podem ser reflexos de choques externos, como a Crise da Ásia e a Moratória da Rússia, corroborando, dessa forma, os estudos de Ceretta e Costa (1999), Santos (2000) e Mota e Fernandes (2004). Já em 1999, a desvalorização do real frente ao dólar e o abandono do regime de bandas cambiais pelo país podem ter sido a causa de uma nova elevação da volatilidade do mercado de ações.

Após esse período, a volatilidade do mercado acionário apresentou altas mais moderadas. Em 2001 o Brasil atravessou sua maior crise energética e ocorreu queda de 6,1\% na produção industrial $^{6}$ em relação ao ano anterior. $\mathrm{O}$ ano de 2001 apresentou também forte oscilação no mercado de câmbio, influenciada pelas incertezas no cenário internacional, decorrentes da instabilidade econômica na Argentina e da desaceleração da economia estadunidense. Esses fatores podem ter sido responsáveis pela queda nos preços das ações em 2001, conforme observado na série do IBOVESPA.

\footnotetext{
${ }^{6}$ Dados DIEESE, disponível em http://www.cnbcut.com.br/dieese/ConjEconFEV02.doc, acesso em 15/2/2007.
} 
O aumento da volatilidade no ano de 2002 pode ter sido o reflexo das expectativas causadas no mercado devido às já comentadas eleições presidenciais, além do possível ataque americano ao Iraque (após os atentados de 11 de setembro de 2001).

Nos anos subseqüentes (2003, 2004 e 2005), com a baixa gradual da taxa de juros e do risco país e a valorização cambial, os preços das ações apresentaram trajetória crescente. Durante esse três anos ocorreram as menores volatilidades de todo o período analisado.

\subsection{Comparação das Volatilidades dos Mercados de Renda Variável e Renda Fixa}

\subsubsection{IBOVESPA e CDI}

As volatilidades dos mercados de renda fixa e variável são apresentadas, conjuntamente, pela Figura 16. A volatilidade do mercado de renda variável é representada pela linha de cor vermelha e a linha de cor preta representa a volatilidade do mercado de renda fixa.

Pode-se observar que os dois mercados obtiveram movimentos bem semelhantes em suas volatilidades, ao longo do período analisado. 


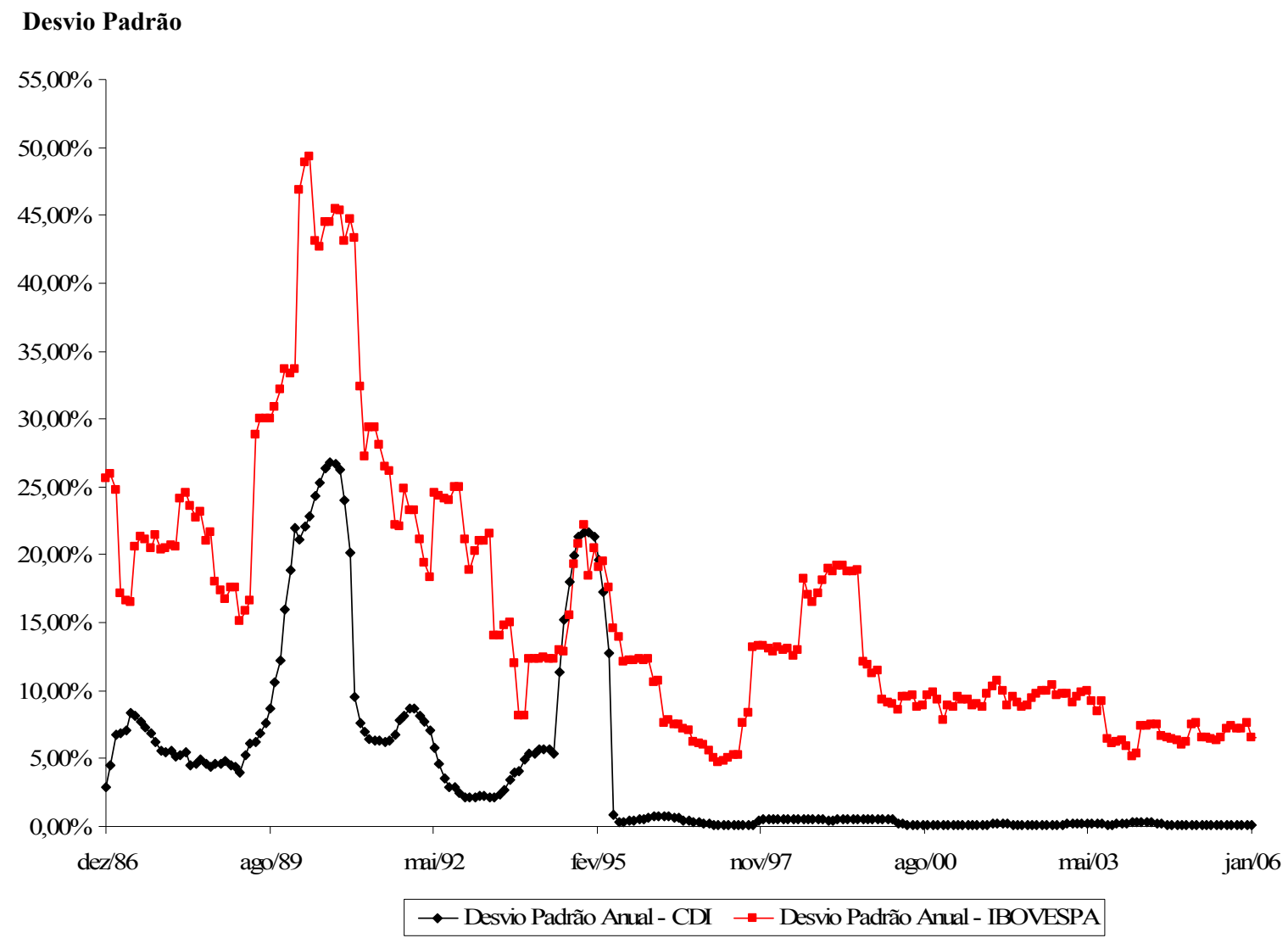

Figura 16: Desvio Padrão Anual dos Retornos Mensais -CDI e IBOVESPA - dez./86 a fev./06.

Os resultados apresentados na Figura 16 estão descritos na Tabela 3, que mostra as dez maiores e menores volatilidades do período.

$\mathrm{Na}$ Tabela 3, a coluna ano refere-se aos meses de dezembro de cada ano do período analisado. Equivalem aos desvios padrão discretos, ou seja, o desvio padrão calculado para cada ano, com base nos retornos mensais do ativo, considerando os meses de janeiro a dezembro. A exceção, conforme já foi mencionado, é o ano de 1986, em que o desvio padrão discreto foi calculado para os meses de março a dezembro, devido ao início da amostra. 
Tabela 3: Resumo Estatístico Para os Mercados de Renda Fixa e Variável -Maiores e Menores Volatilidades.

\begin{tabular}{|c|c|c|c|c|c|c|c|}
\hline \multicolumn{4}{|c|}{ Altas Volatilidades/Ano } & \multicolumn{4}{|c|}{ Baixas Volatilidades/Ano } \\
\hline \multicolumn{2}{|r|}{ CDI } & \multicolumn{2}{|c|}{ IBOVESPA } & \multicolumn{2}{|c|}{ CDI } & \multicolumn{2}{|c|}{ IBOVESPA } \\
\hline Ano & $\begin{array}{c}\text { Desvio Padrão } \\
\text { do Retorno }\end{array}$ & Ano & $\begin{array}{l}\text { Desvio Padrão } \\
\text { do Retorno }\end{array}$ & Ano & $\begin{array}{l}\text { Desvio Padrão } \\
\text { do Retorno }\end{array}$ & Ano & $\begin{array}{c}\text { Desvio } \\
\text { Padrão do } \\
\text { Retorno }\end{array}$ \\
\hline $\operatorname{dez} / 90$ & $23,970007 \%$ & $\mathrm{dez} / 90$ & $43,13598 \%$ & $\operatorname{dez} / 99$ & $0,560264 \%$ & $\operatorname{dez} / 95$ & $12,17433 \%$ \\
\hline $\mathrm{dez} / 94$ & $21,690076 \%$ & $\mathrm{dez} / 89$ & $33,70621 \%$ & $\mathrm{dez} / 97$ & $0,516785 \%$ & $\mathrm{dez} / 01$ & $9,92405 \%$ \\
\hline $\mathrm{dez} / 89$ & $15,988864 \%$ & $\mathrm{dez} / 86$ & $25,59344 \%$ & $\mathrm{dez} / 98$ & $0,491845 \%$ & $\mathrm{dez} / 02$ & $9,80880 \%$ \\
\hline $\operatorname{dez} / 91$ & $8,198979 \%$ & $\operatorname{dez} / 91$ & $24,88140 \%$ & dez/96 & $0,228379 \%$ & dez/99 & $9,34616 \%$ \\
\hline $\mathrm{dez} / 87$ & $5,483764 \%$ & $\mathrm{dez} / 94$ & $22,18958 \%$ & $\mathrm{dez} / 03$ & $0,226339 \%$ & dez/93 & $8,10691 \%$ \\
\hline $\mathrm{dez} / 93$ & $4,969770 \%$ & $\operatorname{dez} / 92$ & $21,14426 \%$ & $\mathrm{dez} / 01$ & $0,162875 \%$ & $\mathrm{dez} / 00$ & $7,83009 \%$ \\
\hline $\mathrm{dez} / 88$ & $4,776202 \%$ & $\operatorname{dez} / 87$ & $20,44355 \%$ & $\mathrm{dez} / 02$ & $0,137958 \%$ & $\mathrm{dez} / 05$ & $7,18517 \%$ \\
\hline $\mathrm{dez} / 86$ & $2,895502 \%$ & dez/98 & $18,11125 \%$ & $\mathrm{dez} / 05$ & $0,113100 \%$ & $\mathrm{dez} / 03$ & $6,31385 \%$ \\
\hline dez/92 & $2,178904 \%$ & $\operatorname{dez} / 88$ & $16,75696 \%$ & $\mathrm{dez} / 00$ & $0,103321 \%$ & dez/96 & $6,01784 \%$ \\
\hline $\mathrm{dez} / 95$ & $0,587762 \%$ & dez/97 & $13,33296 \%$ & $\mathrm{dez} / 04$ & $0,099060 \%$ & dez/04 & $5,97844 \%$ \\
\hline
\end{tabular}

Média do Desvio Padrão do CDI (N=20): 4,669\% $\quad$ Média do Desvio Padrão do IBOVESPA (N=20): 16,099\% Média do Desvio Padrão do CDI (N=231): 4,266\% Média do Desvio Padrão do IBOVESPA (N=231): 15,947\%

Conforme exposto na Figura 15 e na Tabela 3, as altas volatilidades dos dois mercados estão presentes em grande parte nos mesmos anos. Entre as dez maiores volatilidades dos dois mercados, nove se encontram presentes no mesmo ano para as duas classes de ativos. Isso ocorre em 1986, 1987, 1988, 1989, 1990, 1991, 1992, 1994 e 1995. Das cinco maiores volatilidades, quatro foram coincidentes entre os dois mercados (nos anos de 1989, 1990, 1991 e 1994), por fatores já expostos anteriormente.

Dessa forma, rejeita-se a hipótese nula $\left(\mathbf{H}_{0}\right)$ da Hipótese $\mathbf{1}$ em favor da hipótese alternativa $\left(\mathbf{H}_{\mathbf{1}}\right)$ de que os mercados possuem picos coincidentes de volatilidade.

A Hipótese 1 está assim descrita:

$\mathbf{H}_{\mathbf{0}}$ : As duas séries de retornos (renda fixa e renda variável) no mercado brasileiro não possuem picos de volatilidade coincidentes ao longo do período de tempo estudado.

$\mathbf{H}_{1}$ : As duas séries de retornos (renda fixa e renda variável) no mercado brasileiro possuem picos de volatilidade coincidentes ao longo do período de tempo estudado. 
Esses resultados encontrados para o mercado brasileiro diferem significativamente dos resultados encontrados nos EUA e países europeus (Alemanha, Suíça e Reino Unido), já que nesses estudos os picos de volatilidades não foram coincidentes entre os dois mercados.

Conforme observado na Figura 16 e na Tabela 3, houve uma mudança considerável no padrão de volatilidade das duas classes de ativos, antes e depois da implantação do Plano Real (tanto que a ilustração da volatilidade do CDI teve de ser dividida em dois gráficos distintos), o que pode sugerir que as variáveis macroeconômicas interferem de maneira decisiva na volatilidade dos ativos do mercado financeiro. Sendo assim, rejeita-se a hipótese nula $\left(\mathbf{H}_{\mathbf{0}}\right)$ em favor da hipótese alternativa $\left(\mathbf{H}_{1}\right)$ da Hipótese $\mathbf{2}$ deste trabalho, assim descrita:

\section{* Hipótese 2:}

$\mathbf{H}_{\mathbf{0}}$ : $\underline{\text { Não }}$ houve mudança considerável no padrão de volatilidade das duas classes de ativos após a implantação do Plano Real em 1994.

$\mathbf{H}_{1}$ : Houve mudança considerável no padrão de volatilidade das duas classes de ativos após a implantação do Plano Real em 1994.

Para melhor entendimento da relação entre os dois mercados, calculou-se a razão entre as volatilidades das duas classes de ativos, ou seja, o desvio padrão dos retornos mensais do mercado de renda fixa dividido pelo desvio padrão dos retornos mensais do mercado de renda variável. A Figura 17 mostra que essa relação não é estável ao longo do tempo, já que a razão varia de 0,0064 a 1,038. A linha de tendência decrescente (obtida através do programa MS Excel $^{\circledR}$ ) ainda evidencia que a volatilidade do IBOVESPA, no decorrer do período, tem diminuído menos que a volatilidade do CDI. 


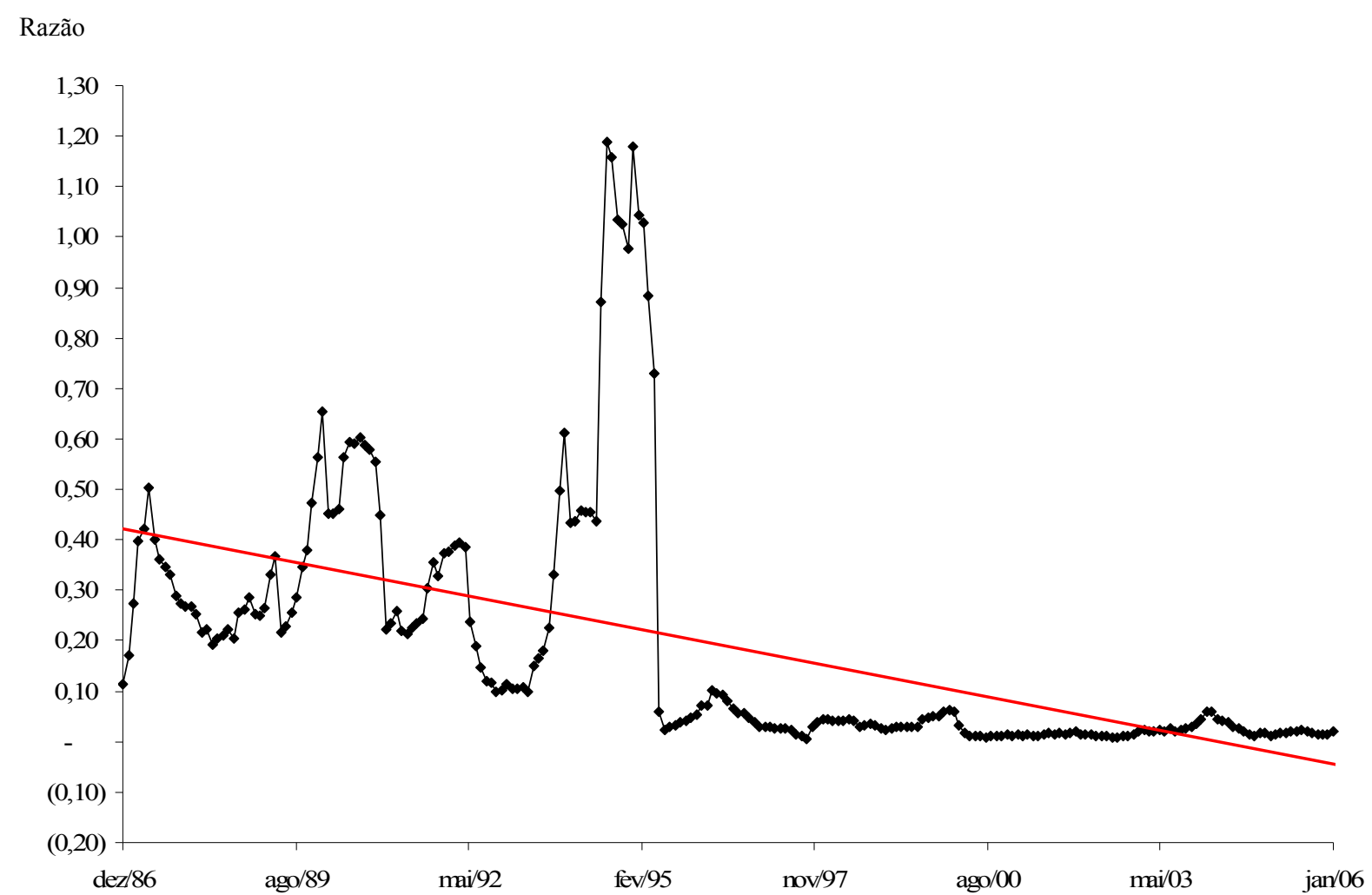

Figura 17: Razão do Desvio Padrão Anual dos Retornos Mensais -CDI e IBOVESPA - dez./06 a fev./06.

Portanto não foi possível rejeitar a hipótese nula $\left(\mathbf{H}_{\mathbf{0}}\right)$ da Hipótese 3 do estudo, nesse caso rejeita-se a hipótese alternativa $\left(\mathbf{H}_{1}\right)$ :

\section{Hipótese 3:}

$\mathbf{H}_{\mathbf{0}}$ : A relação entre as volatilidades das duas classes de ativos não é estável ao longo de todo o período estudado.

$\mathbf{H}_{1}$ : A relação entre as volatilidades das duas classes de ativos é estável ao longo de todo o período estudado.

Neste ponto do estudo, os resultados foram semelhantes aos encontrados pelos autores que analisaram a volatilidade dos mercados estadunidense e europeu, pois em todos os países 
analisados (EUA, Reino Unido, Suíça e Alemanha), as volatilidades não mantiveram padrão estável de relacionamento durante o período pesquisado pelos autores.

Como já era esperado, há uma maior concentração de maiores razões no período anterior a implantação do Plano Real, período em que as volatilidades dos dois mercados foram mais altas, conforme descrito na Tabela 4.

Tabela 4: Resumo Estatístico Para a Razão dos Mercados de Renda Fixa e Variável -Maiores e Menores Razões.

\begin{tabular}{|c|c|c|c|}
\hline \multicolumn{2}{|c|}{ Maiores } & \multicolumn{2}{|c|}{ Menores } \\
\hline Ano & Razão & Ano & Razão \\
\hline $\mathrm{dez} / 99$ & 0,056339 & $\mathrm{dez} / 00$ & 0,013195 \\
\hline $\mathrm{dez} / 92$ & 0,091456 & $\operatorname{dez} / 02$ & 0,014065 \\
\hline $\mathrm{dez} / 86$ & 0,114312 & $\operatorname{dez} / 05$ & 0,015741 \\
\hline $\mathrm{dez} / 88$ & 0,210982 & $\operatorname{dez} / 01$ & 0,016412 \\
\hline $\mathrm{dez} / 91$ & 0,236281 & $\operatorname{dez} / 04$ & 0,016570 \\
\hline $\operatorname{dez} / 87$ & 0,250778 & $\operatorname{dez} / 98$ & 0,027157 \\
\hline $\operatorname{dez} / 89$ & 0,423831 & $\mathrm{dez} / 03$ & 0,035848 \\
\hline $\operatorname{dez} / 93$ & 0,439192 & $\operatorname{dez} / 96$ & 0,037950 \\
\hline $\mathrm{dez} / 90$ & 0.523044 & $\mathrm{dez} / 97$ & 0.038760 \\
\hline $\mathrm{dez} / 94$ & 0,743991 & $\mathrm{dez} / 95$ & 0,048279 \\
\hline
\end{tabular}

Média da Razão dos Desvios padrão ( $\mathrm{N}=20)$ : 0,20217

Média da Razão dos Desvios padrão (N=231): 0,18879

Uma outra medida de risco calculada foi o risco sistemático presente entre os mercados. O coeficiente $\beta$ (beta), estimou qual foi a variação de um mercado em relação a variação do outro.

O coeficiente foi calculado, assim como o desvio padrão, para o ano calendário discreto, conforme apresentado pela Tabela 6, e para o ano calendário contínuo, conforme exposto na Figura 18. 
Tabela 5: Resumo Coeficiente Beta CDI $=f($ IBOVESPA $)-$ dez $/ 86$ a dez/05

\begin{tabular}{|c|c|c|c|}
\hline \multicolumn{2}{|c|}{ Maiores } & \multicolumn{2}{|c|}{ Menores } \\
\hline Ano & Beta & Ano & Beta \\
\hline $\mathrm{dez} / 87$ & 0,0077797 & $\mathrm{dez} / 93$ & $(0,0693089)$ \\
\hline $\mathrm{dez} / 99$ & 0,0091222 & $\mathrm{dez} / 88$ & $(0,0356654)$ \\
\hline $\mathrm{dez} / 96$ & 0,0108839 & $\mathrm{dez} / 03$ & $(0,0165092)$ \\
\hline $\operatorname{dez} / 98$ & 0,0121253 & $\mathrm{dez} / 05$ & $(0,0028540)$ \\
\hline $\operatorname{dez} / 95$ & 0,0156111 & $\mathrm{dez} / 97$ & $(0,0027300)$ \\
\hline $\mathrm{dez} / 92$ & 0,0441080 & $\mathrm{dez} / 01$ & 0,0012357 \\
\hline $\operatorname{dez} / 90$ & 0,0715790 & $\mathrm{dez} / 86$ & 0,0024802 \\
\hline $\mathrm{dez} / 89$ & 0,1129481 & $\mathrm{dez} / 00$ & 0,0031324 \\
\hline $\mathrm{dez} / 91$ & 0,1148852 & $\mathrm{dez} / 02$ & 0,0042550 \\
\hline $\mathrm{dez} / 94$ & 0,7533564 & $\mathrm{dez} / 04$ & 0,0046185 \\
\hline
\end{tabular}

Média do Coeficiente Beta ( $\mathrm{N}=20): 0,05205$

Média do Coeficiente Beta ( $=231)$ : 0,05413

De acordo com a Tabela 5, o maior beta entre os mercados foi encontrado em 1994, o que corrobora a Figura 18, que evidencia que no final de 1994 até o início de 1995 houve um aumento muito considerável do risco sistemático entre os dois mercados, o qual foi aparentemente equilibrado após a implantação definitiva do Plano Real.

Assim como expresso na Figura 18(a), o coeficiente $\beta$ apresentou uma significativa mudança de escala após meados do ano de 1995, da mesma forma que a volatilidade do mercado de renda fixa. Para melhor compreensão da análise, a Figura 18(b) expõe a mudança do risco sistemático entre os mercados de julho de 1995 a fevereiro de 2006.

Os períodos em que o coeficiente beta se mostrou menor que zero possibilita a interpretação de que as taxas de retorno do mercado de renda fixa obtiveram movimentos contrários às taxas de retorno das ações (os betas muito inferiores a zeros constam no final de 1987, final de 1988, o início e o final de 1991, durante todo o ano de 1997, a primeira metade de 1998, quase todo o ano de 2002 e todo o ano de 2005). 
(a)

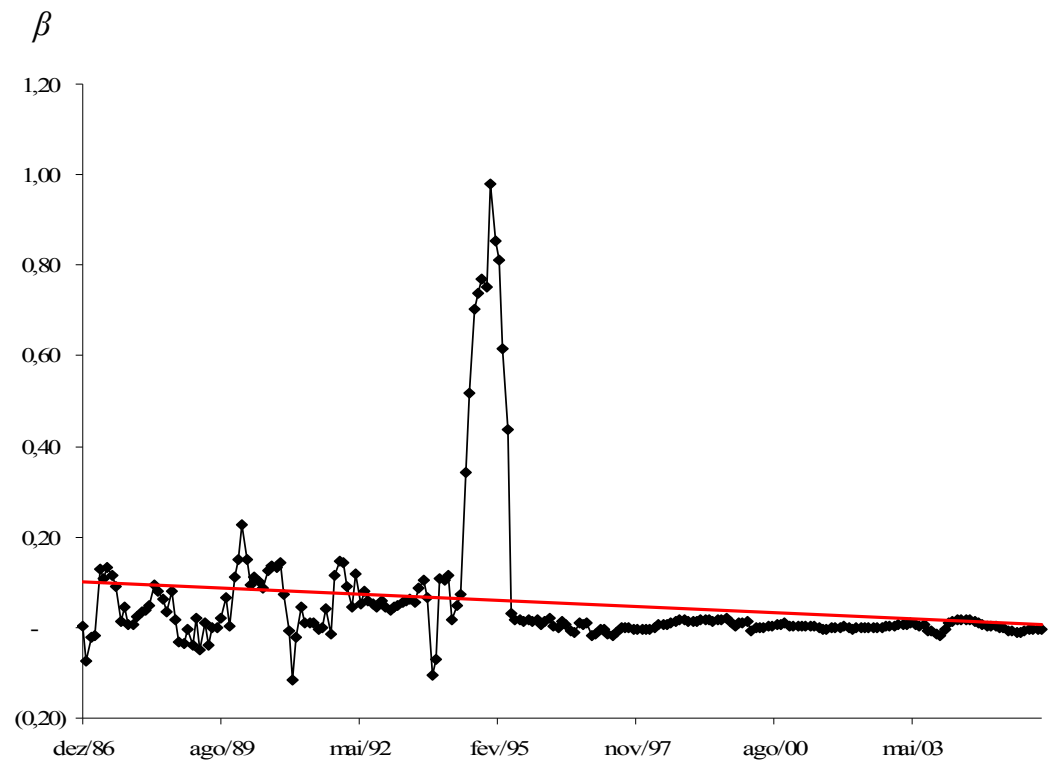

(b)

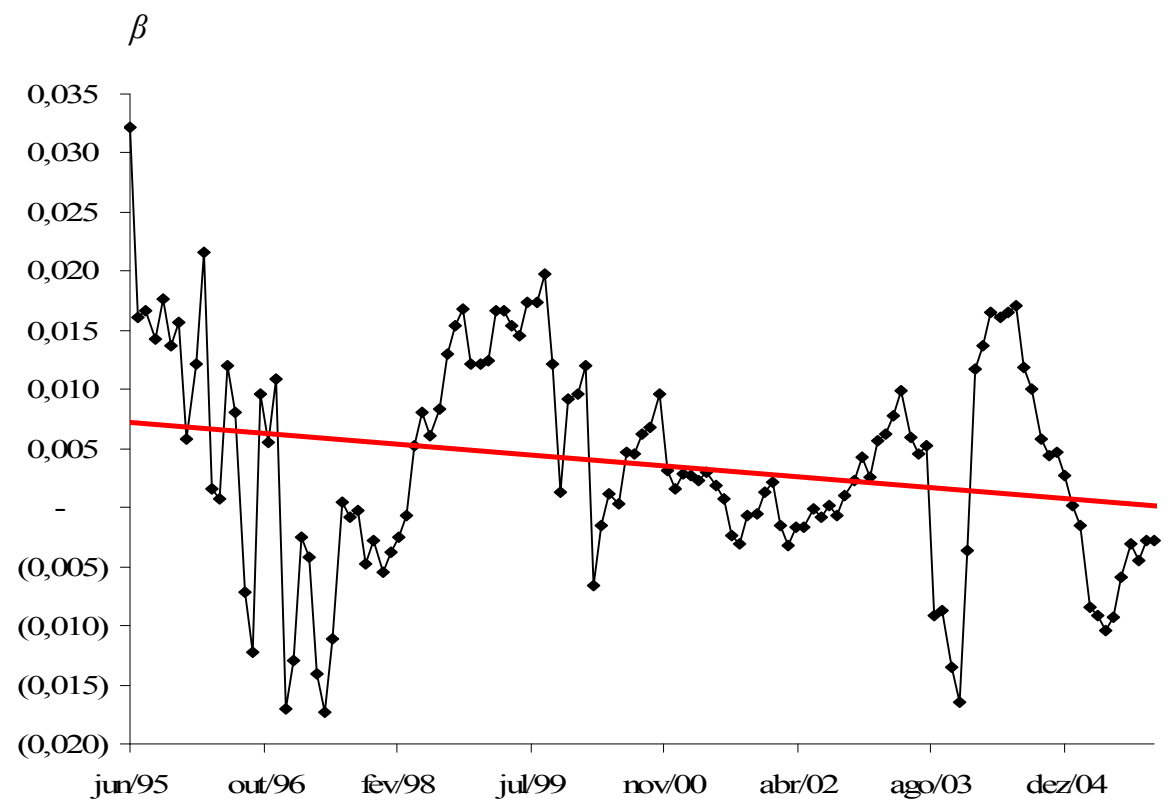

Figura 18: Coeficiente Beta CDI $=\mathrm{f}($ IBOVESPA $)-$ dez./86 a fev./06 (a) e Coeficiente Beta CDI $=\mathrm{f}($ IBOVESPA $)-$ jul./95 a fev./06 (b).

Como a correlação é um importante fator de explicação do $\beta$, já que o mesmo é determinado pela razão entre a covariância e a variância, e a covariância se explica pela correlação multiplicada pelos desvios padrão, então a correlação entre os retornos dos mercados se mostra um importante fator impactante na mudança de risco sistemático. 
Em relação à correlação entre os dois mercados, a Figura 19(a) descreve a mudança de correlação entre os retornos dos dois mercados analisados, renda fixa e renda variável, no período de março de 1986 a fevereiro de 2006, e a Figura 19(b) enuncia os mesmos dados de julho de 1995 a fevereiro de 2006.

De acordo com as figuras expostas, a correlação entre os dois mercados tem um padrão comportamental, ao longo do tempo, similar ao comportamento do coeficiente beta, principalmente no período de 1995 a 2006 . A correlação mais alta do período apresentado se refere ao período de fevereiro de 1994 a janeiro de 1995, onde a correlação ficou em torno de 0,85 , conseqüentemente gerando um coeficiente beta também de maior valor do período em torno de 0,87 .

As linhas de tendências dos dois coeficientes (beta e correlação) analisados se mostraram igualmente negativas, sugerindo uma diminuição do risco entre as duas classes de ativos. As maiores mudanças observadas no coeficiente beta e na correlação entre as duas classes de ativos ao longo do período analisado sugerem que a relação entre eles não é estável ao longo do tempo, o que já havia sido observado anteriormente. 
(a) Correlação

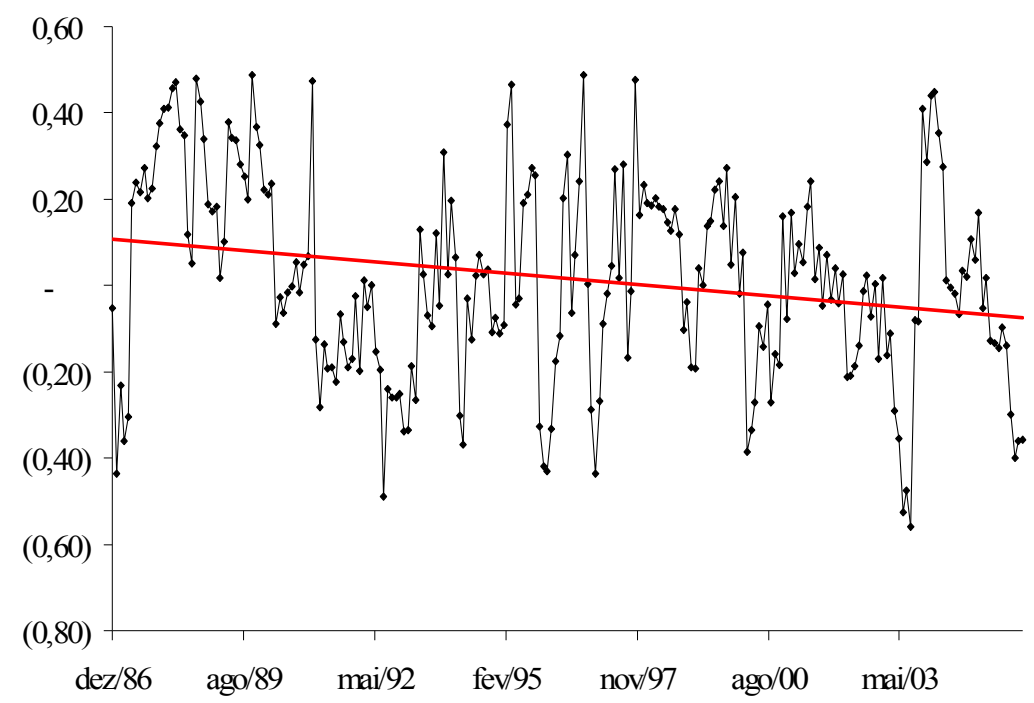

(b) Correlação

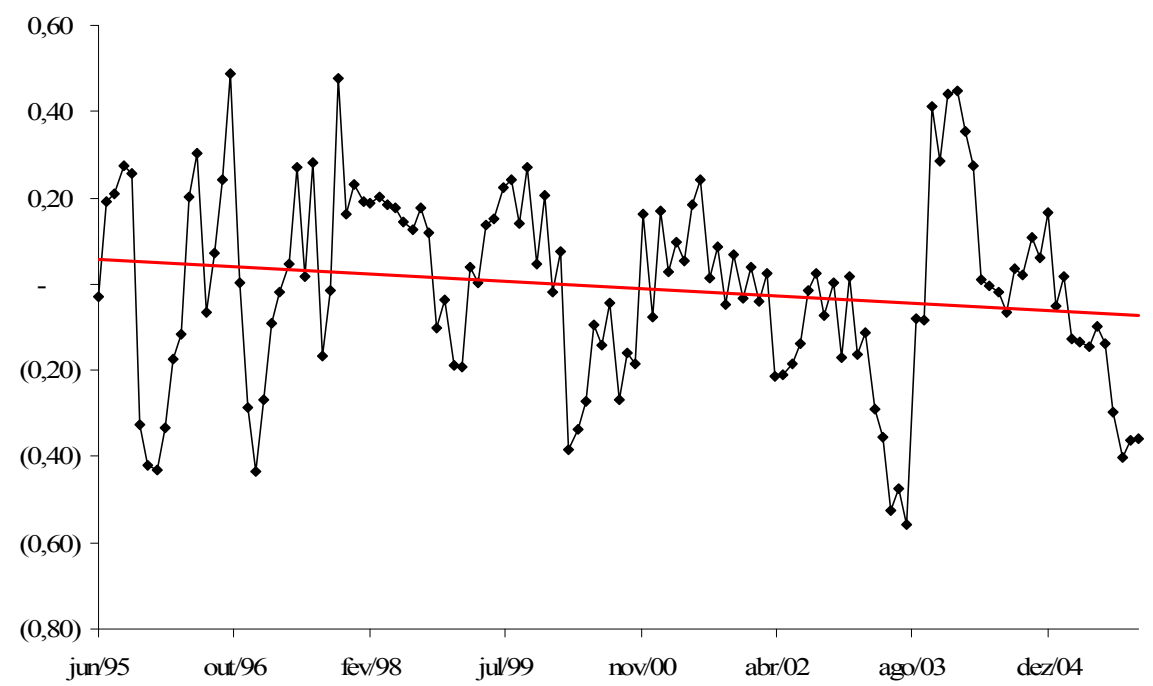

Figura 19: (a) Correlação CDI e IBOVESPA - dez./86 a fev./06 e(b) Correlação CDI e IBOVESPA- jul./95 a fev./06.

Com o objetivo de compreender o quanto um mercado foi, na média, mais volátil que o outro, no período de 1986-2006, foi realizado o Teste de Hipótese para Diferença entre Duas Médias, ao nível de significância de 5\%, o qual resultou nos dados da Tabela 6: 
Tabela 6: Teste-t - duas amostras para médias (IBOVESPA e CDI)

\begin{tabular}{lrr}
\hline & IBOVESPA & \multicolumn{1}{c}{ CDI } \\
\hline Média & 0,177888657 & 0,042845922 \\
Variância conhecida & 0,01287 & 0,00429 \\
Observações & 231 & 231 \\
Hipótese da diferença de média & 0 & \\
$\mathbf{t}$ & $\mathbf{1 5 , 6 7}$ & \\
$\mathrm{P}(\mathrm{Z}<=\mathrm{z})$ uni-caudal & 0,00 & \\
$\mathbf{z}$ crítico uni-caudal & $\mathbf{1 , 6 4}$ & \\
$\mathrm{P}(\mathrm{Z}<=\mathrm{z})$ bi-caudal & 0,00 & \\
$\mathbf{z}$ crítico bi-caudal & $\mathbf{1 , 9 6}$ & \\
\hline
\end{tabular}

De acordo com os valores críticos de $\mathbf{z}$ expostos na Tabela 6, rejeita-se a hipótese nula de que as médias sejam estatisticamente iguais. Como a diferença entre as médias é de 0,13504 e o erro padrão ou amostral é de 0,00861 , o intervalo de confiança de $95 \%$ para essa diferença é de:

\section{$0,13504 \pm 1,96 \times 0,00861=(0,11814 ; 0,15193)$}

ou seja, estimou-se que a diferença entre as volatilidades para as duas séries se encontra entre 0,11814 e 0,15193 .

Assim sendo, de acordo com essas estimativas, durante o período 1986-2006, a volatilidade do IBOVESPA foi cerca de $76 \%$ superior à volatilidade do CDI $(0,13504 \div 0,1778)$, ou cerca de 3,15 vezes maior $(0,13504 \div 0,04284)$. Esse resultado é semelhante ao encontrado pelos autores Reilly, Wright e Chan (2000) nos EUA e Young e Johnson (2004) na Alemanha, embora os autores não tenham realizado teste de diferenças de médias em suas conclusões, apenas limitaram-se a calcular a média de cada série e compará-las.

Em seguida, os mercados de renda fixa e renda variável foram comparados novamente, mas com um outro indicador do mercado de renda fixa, o Índice de Renda Fixa do Mercado. Os resultados encontrados foram comparados também ao CDI. 


\subsubsection{IRF-M, CDI e IBOVESPA}

Embora o IRF-M (Índice de Renda Fixa do Mercado) seja um parâmetro para o mercado de renda fixa, assim como o CDI, por sua carteira ser composta de Letras do Tesouro Nacional, que são títulos pré-fixados, e sua rentabilidade ser calculada por meio da variação do preço desta carteira, a volatilidade de seus retornos mensais se mostrou maior que a volatilidade dos retornos do CDI, conforme já era esperado.

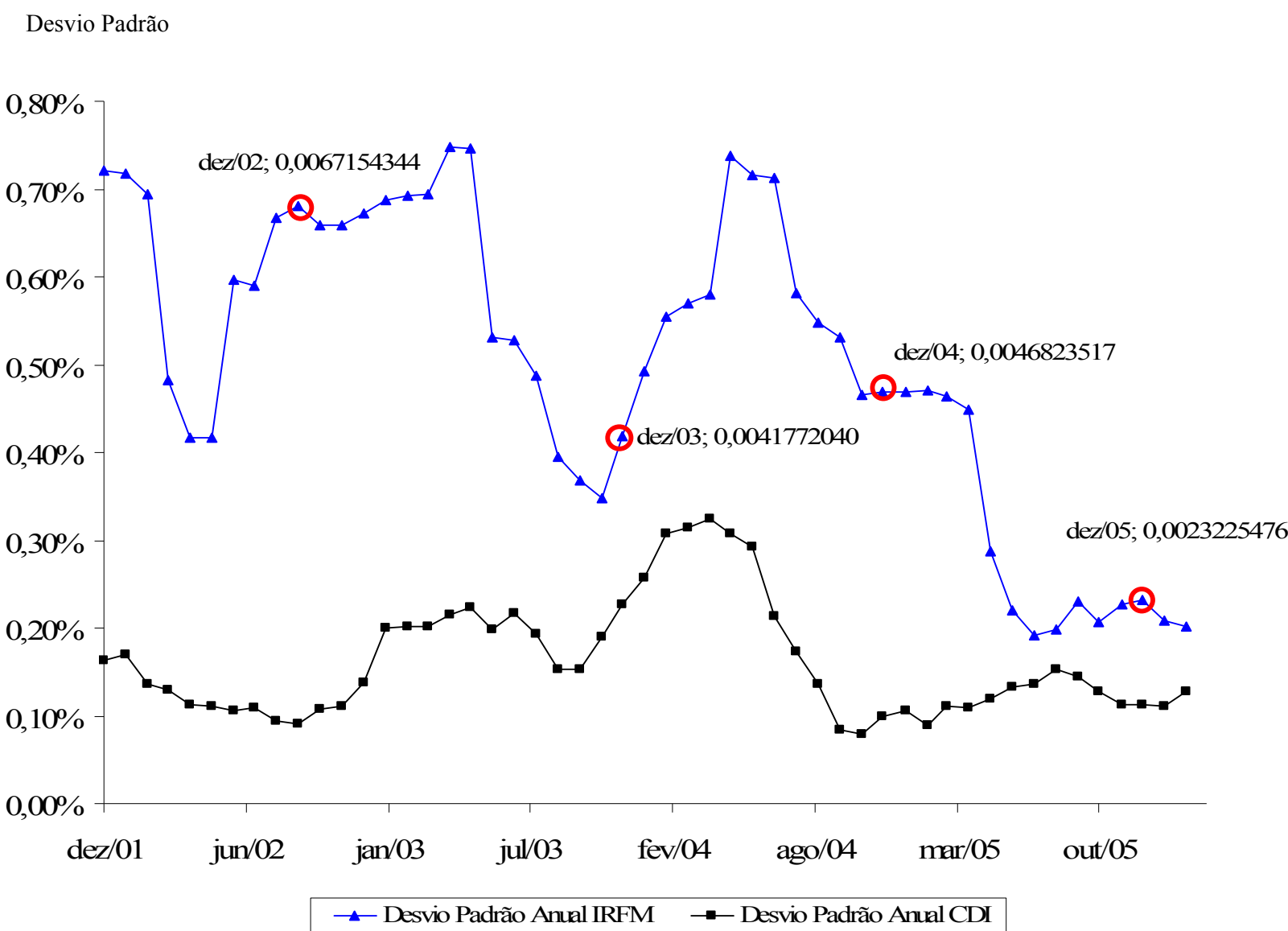

Figura 20: Desvio Padrão Anual dos Retornos Mensais -IRFM e CDI- dez./01 a fev./06.

O gráfico aqui representado pela Figura 20 exibe as volatilidades dos dois mercados no período de tempo de dezembro de 2001 a fevereiro de 2006. O ano de 2002 foi um dos anos de 
maior volatilidade apresentada pelo IRF-M. Acredita-se que seja pelo mesmo motivo que elevou a volatilidade dos outros dois ativos, a eleição presidencial.

O ano de 2003 se inicia com a volatilidade em alta devido a fortes pressões inflacionárias, aumento do risco-país, e uma certa fuga de capital. Logo após os primeiros meses do governo Lula, a volatilidade do IRF-M regride consideravelmente, o que pode ser atribuído à percepção do mercado de que o governo Lula continuaria com a política econômica do governo anterior, e à redução da taxa básica de juros, o que pode ter acalmado novamente os ânimos dos investidores e gestores de portfólios.

Durante o ano de 2004, ocorreu uma nova alta na volatilidade dos retornos do IRF-M. Isso pode ser atribuído à queda gradual nas taxas de juros nominais, que, após a segunda metade do mesmo ano, aumentou novamente fazendo a volatilidade retroceder e permanecer em queda até o final de 2005 .

Embora a volatilidade dos retornos do IRF-M seja consideravelmente maior que os retornos do CDI, os dois exibem movimentação similar em seus desvios padrão. Para melhor compreensão dessa relação, o gráfico apresentado pela Figura 21 exibe os retornos mensais dos dois benchmarks usados para análise do mercado de renda fixa. 


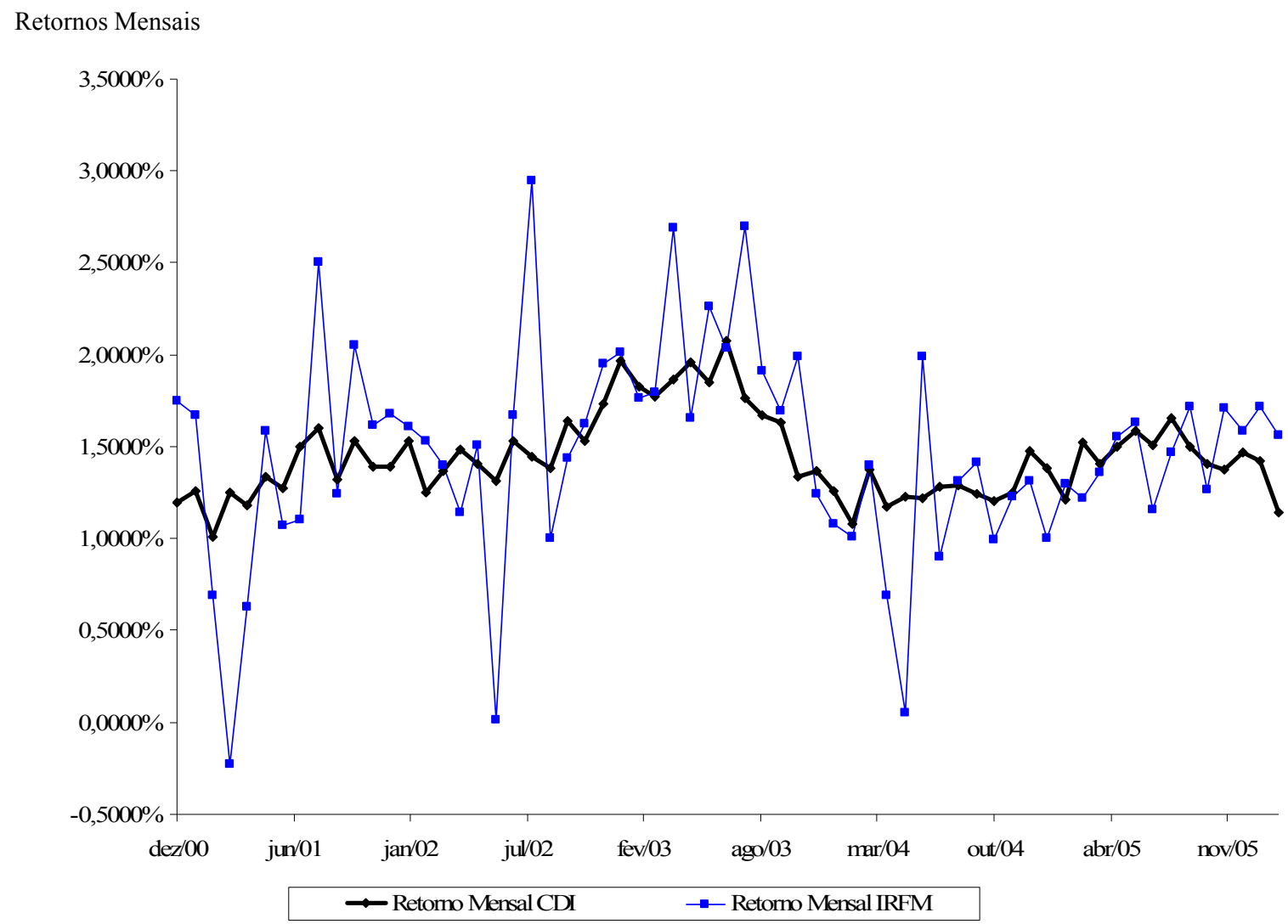

Figura 21: Retornos Mensais -IRFM e CDI - dez./01 a fev./06.

Mesmo os retornos do CDI sendo mais estáveis durante o período 2000-2006 do que os retornos do IRF-M, toda a variação de retornos do segundo ocorre em torno da variação do primeiro, embora a oscilação entre os retornos do IRF-M seja maior que a do CDI, o que foi observado pela volatilidade dos ativos na Figura 20. Por ser uma carteira de títulos pré-fixados, como já mencionado anteriormente, era esperado que a volatilidade de seus retornos fosse maior, já que o IRF-M, mesmo sendo um índice de renda fixa, pode vir a apresentar retornos variáveis devido à composição de sua carteira.

A Figura 22 exibe o gráfico comparativo entre os dois indicadores do mercado de renda fixa - IRF-M e CDI - e o indicador do mercado de renda variável, IBOVESPA. O mercado de 
renda variável foi mais volátil que o mercado de renda fixa, mesmo comparado aos dois indicadores, no período de dezembro de 2001 a fevereiro de 2006.

A Tabela 7 exibe a relação do IBOVESPA com o IRF-M, em relação às volatilidades dos dois mercados, a razão entre essas volatilidades e o risco sistemático $(\beta)$ presente entre eles.

Desvio Padrão

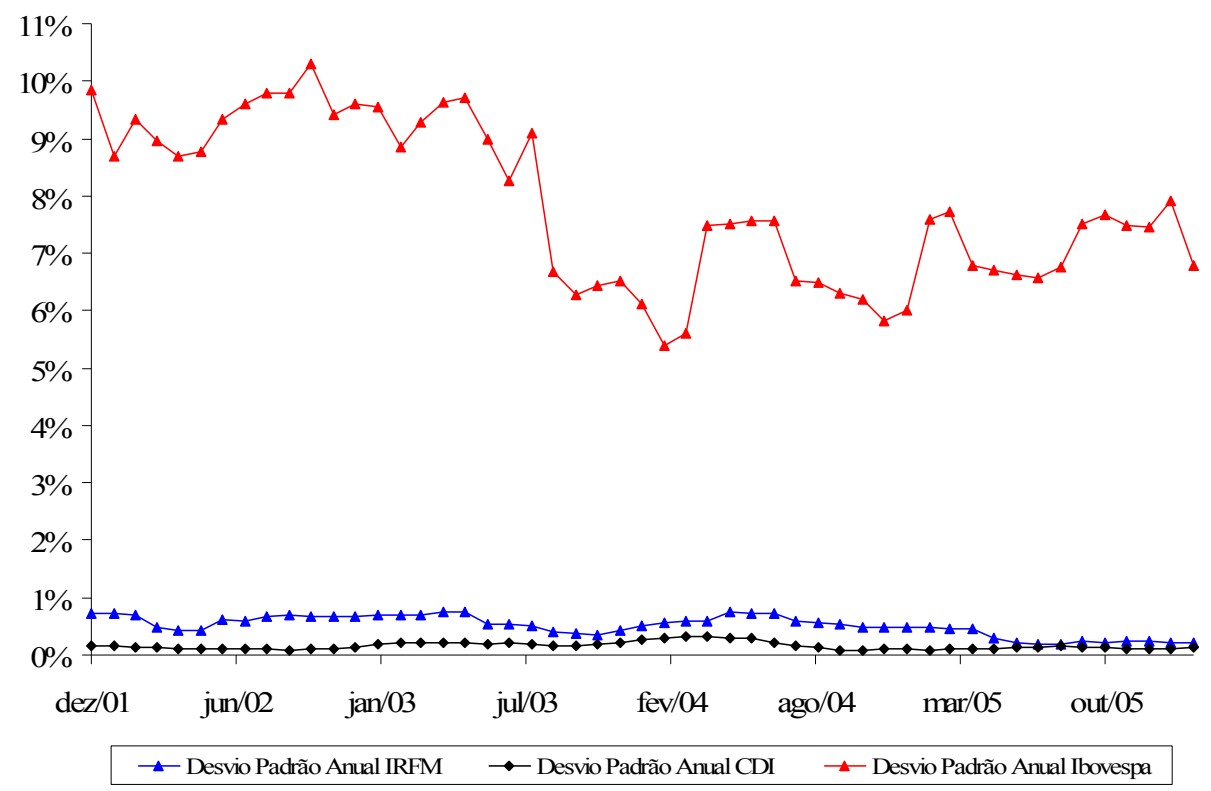

Figura 22: Desvio Padrão Anual dos Retornos Mensais -IRFM, CDI e IBOVESPA - dez./01 a fev./06.

Tabela 7: Resumo Estatístico dos Desvios padrão Anuais IRF-M e IBOVESPA, da Razão dos Desvios padrão Anuais IRF-M/IBOVESPA e Coeficiente Beta IRF-M= $f$ (IBOVESPA) - dez./01 a fev./06.

\begin{tabular}{|c|c|c|c|c|}
\hline Mês & $\begin{array}{l}\text { Desvio Padrão } \\
\text { Anual - IRFM } \\
\end{array}$ & $\begin{array}{c}\text { Desvio Padrão Anual - } \\
\text { IBOVESPA }\end{array}$ & Razão & Betas \\
\hline $\mathrm{dez} / 01$ & $0,720955 \%$ & $9,834117 \%$ & 0,073312 & $(0,0071417)$ \\
\hline $\mathrm{dez} / 02$ & $0,671543 \%$ & $9,591638 \%$ & 0,070013 & $(0,0158810)$ \\
\hline $\mathrm{dez} / 03$ & $0,417720 \%$ & $6,524163 \%$ & 0,064027 & $(0,0026306)$ \\
\hline $\mathrm{dez} / 04$ & $0,468235 \%$ & $5,835322 \%$ & 0,080242 & $(0,0240867)$ \\
\hline $\mathrm{dez} / 05$ & $0,232255 \%$ & $7,456325 \%$ & 0,031149 & $(0,0101229)$ \\
\hline \multicolumn{3}{|c|}{ 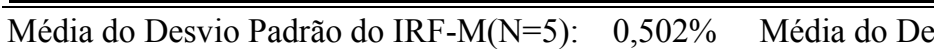 } & $\overline{\text { ão do IBOV }}$ & $=5): \quad 7,848 \%$ \\
\hline \multicolumn{3}{|c|}{ Média do Desvio Padrão do IRF-M $(\mathrm{N}=49)$ : $0,496 \%$} & rão do IBOV & $=49): 7,815 \%$ \\
\hline \multicolumn{3}{|c|}{ Média do Coeficiente Beta $(\mathrm{N}=5):(0,01261)$} & Desvios padr & 0,0637 \\
\hline \multicolumn{3}{|c|}{ Média do Coeficiente Beta $(\mathrm{N}=49):(0,0056)$} & Desvios padr & 0,0636 \\
\hline
\end{tabular}

Assim como foi feito para a relação CDI e IBOVESPA, a razão dos desvios padrão dos retornos do IRF-M e do IBOVESPA, ao longo do período observado, também foi calculada e está 
exposta na Figura 23 e Tabela 8. A relação entre essas duas classes de ativos não é estável ao longo do tempo já que variou de 0,0266 a 0,1046 , mas ainda assim essa relação se mostrou menos instável que a do IBOVESPA com o CDI. A maior razão entre eles aconteceu em fevereiro de 2004, sugerindo que nesse mês a volatilidade do IRF-M foi mais próxima da volatilidade do mercado de ações.

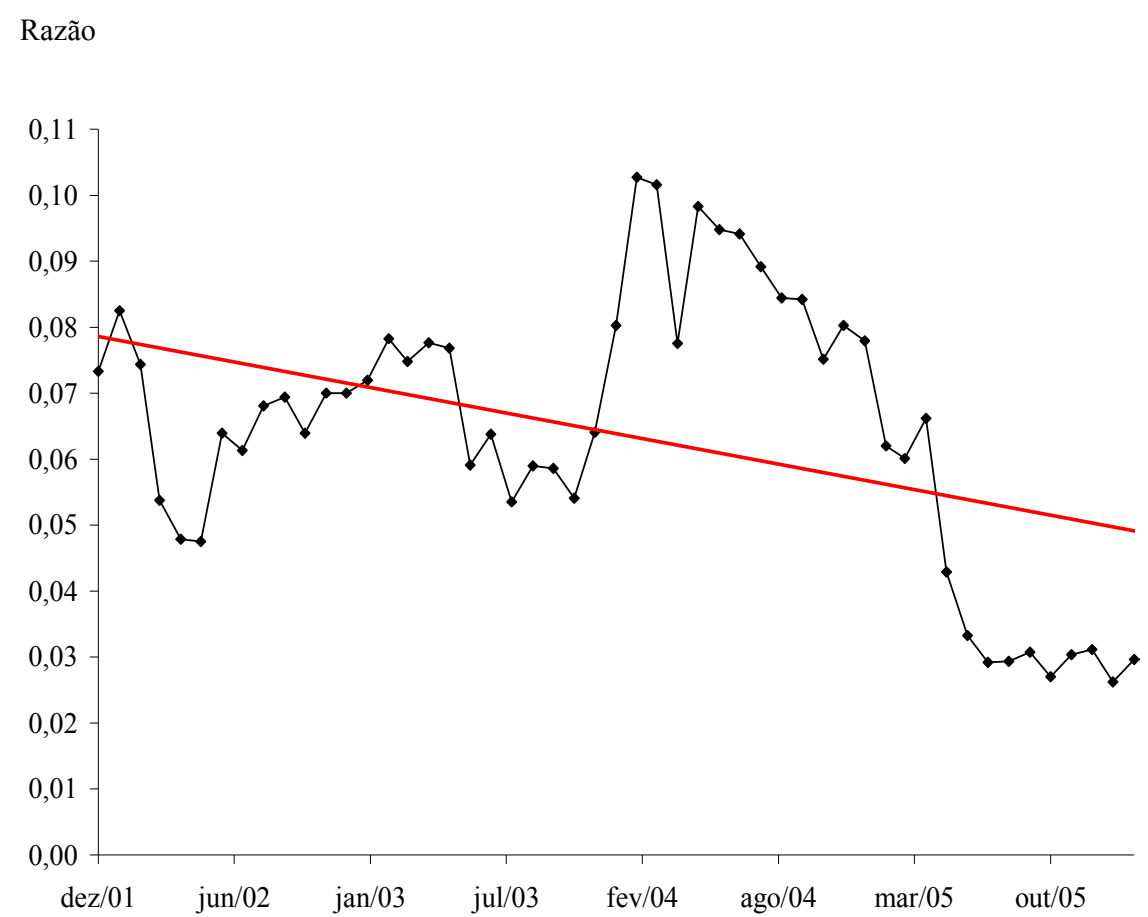

Figura 23: Razão do Desvio Padrão dos Retornos Mensais -IRFM e IBOVESPA - dez./01 a fev./06.

A Figura 24 apresenta os gráficos das movimentações do beta (a), da correlação dos retornos entre o IRF-M e o IBOVESPA (b) e da covariância entre eles (c) de dezembro de 2001 a fevereiro de 2006. Embora ambos, (a) e (b), apresentem movimentações similares, a tendência foi contrária para os dois mercados. A linha de tendência do gráfico (recurso disponível no programa MS Excel ${ }^{\circledR}$ ) (a) é negativa, o que leva a crer que o risco sistemático entre os ativos analisados tem diminuído ao longo do tempo. Porém, a linha de tendência do gráfico (b) sugere 
que a correlação entre ambos tem aumentado. Como a covariância é calculada pela correlação e os desvios padrão,

$$
C O V_{r f, r v}=C O R R_{r f, r v} \times \sigma_{r f} \times \sigma_{r f},
$$

mesmo com a linha de tendência positiva da correlação, a tendência dos desvios padrão foi mais negativa, o que tornou a tendência da covariância negativa e conseqüentemente a do Beta também.

(a)

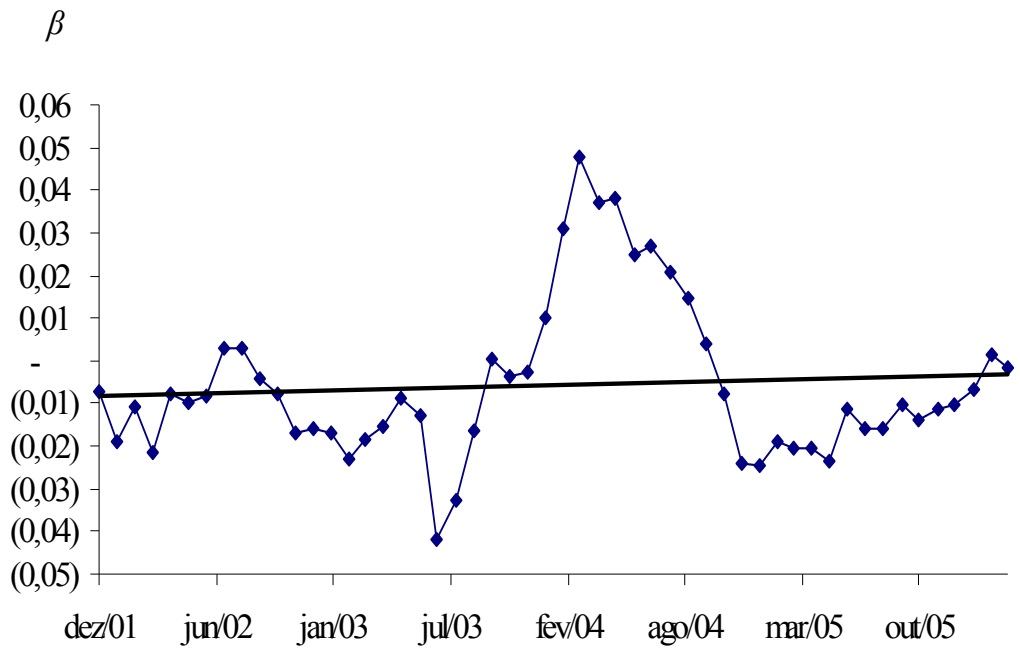

(b)

$$
\text { Correlação }
$$

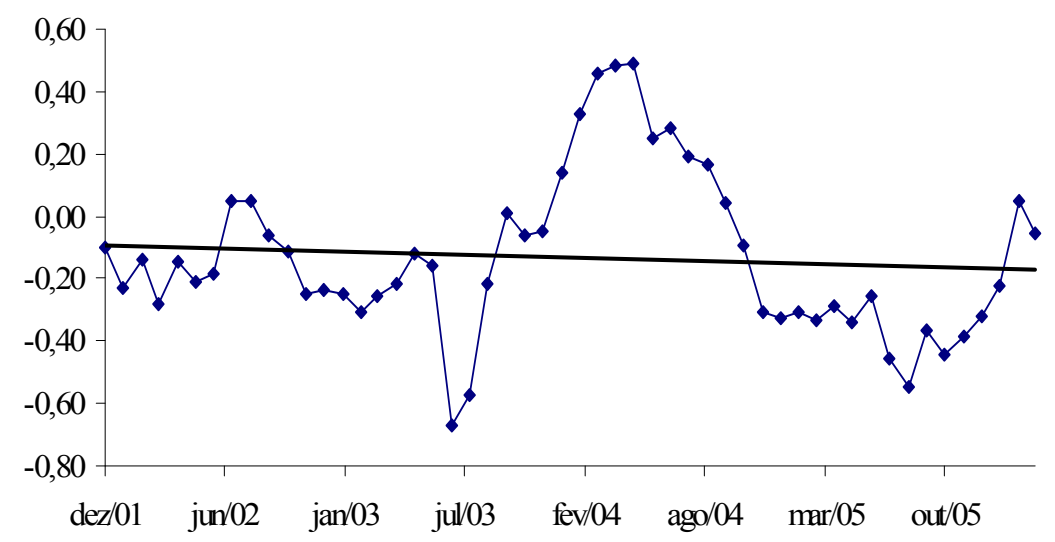


(c)

Covariância

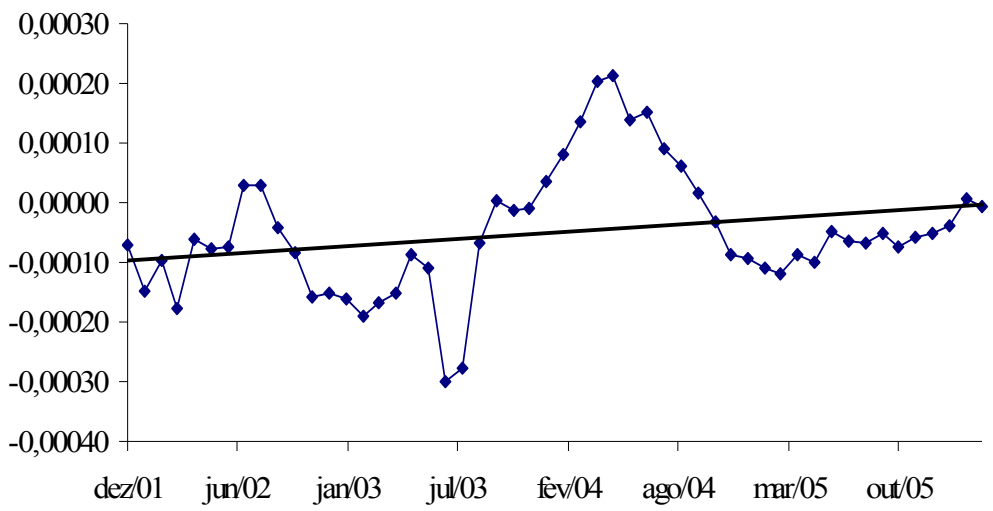

Figura 24: (a) Movimentações do Beta, (b) da Correlação dos retornos (c) e da covariância entre o IRF-M e o IBOVESPA. De dez./01 a fev./06.

A Tabela 8 evidencia o Teste de Hipótese para Diferença entre Duas Médias ao nível de significância de 5\%, para os desvios padrão do IRF-M e do IBOVESPA.

Tabela 8: (a) Teste-t - duas amostras para médias (IBOVESPA e IRF-M) e (b): Teste-t - duas amostras para médias (IBOVESPA e CDI)

(a)

\begin{tabular}{lrr}
\hline & IBOVESPA & \multicolumn{1}{c}{$I R F-M$} \\
\hline Média & 0,078367658 & 0,005024552 \\
Variância conhecida & 0,000193 & 0,00000313 \\
Observações & 51 & 51 \\
Hipótese da diferença de média & 0 & \\
$\mathrm{t}$ & 37,40 \\
$\mathrm{P}(\mathrm{Z}<=\mathrm{z})$ uni-caudal & 0,00 \\
$\mathrm{z}$ crítico uni-caudal & 1,64 \\
$\mathrm{P}(\mathrm{Z}<=\mathrm{z})$ bi-caudal & \multicolumn{3}{c}{0,00} \\
$\mathrm{z}$ crítico bi-caudal & \multicolumn{3}{c}{1,96} \\
\hline
\end{tabular}

(b)

\begin{tabular}{lrr}
\hline & $I B O V E S P A$ & \multicolumn{1}{c}{$C D I$} \\
\hline Média & 0,078367658 & 0,001613808 \\
Variância conhecida & 0,000193 & 0,000000432 \\
Observações & 51 & 51 \\
Hipótese da diferença de média & 0 & \\
$\mathrm{t}$ & 39,41 \\
$\mathrm{P}(\mathrm{Z}<=\mathrm{z})$ uni-caudal & 0,00 \\
$\mathrm{z}$ crítico uni-caudal & 1,64 \\
$\mathrm{P}(\mathrm{Z}<=\mathrm{z})$ bi-caudal & 0,00 \\
$\mathrm{z}$ crítico bi-caudal & \multicolumn{2}{c}{1,96} \\
\hline
\end{tabular}


Dados valores críticos de $z$, rejeita-se a hipótese nula de que as médias dos desvios padrão do IBOVESPA e do IRF-M sejam estatisticamente iguais. Como a diferença entre as médias é de 0,07334 e o erro padrão ou amostral é de 0,00196 , o intervalo de confiança de $95 \%$ para essa diferença é de:

\section{$0,07334 \pm 1,96 \times 0,00196=(0,07718 ; 0,06949)$}

ou seja, estimou-se que a diferença entre as volatilidades para as duas séries se encontra entre 0,07718 e 0,06949 .

De acordo com as estimativas calculadas, durante o período estudado, a volatilidade do IBOVESPA foi cerca de 14 vezes maior que a do IRF-M, e nesse mesmo período a volatilidade do IBOVESPA foi 47 vezes maior que a volatilidade do CDI, já que, de acordo com os dados da Tabela 8(b), o intervalo de confiança de 95\% para a diferença das médias dos desvios padrão dos retornos dos dois ativos foi de $(0,0805 ; 0,0729)$, dado a diferença de média de 0,07675 , e o erro amostral de 0,019475:

\section{$0,07675 \pm 1,96 \times 0,019475=(0,0805 ; 0,0729)$.}

Foi calculado também Teste de Hipótese para Diferença entre Duas Médias, considerando as séries do CDI e do IRF-M, pois já que ambos são títulos do mercado de renda fixa e, como já observado anteriormente, os retornos do IRF-M possuem uma variação maior que os retornos do CDI, buscou-se conhecer o quanto a volatilidade do IRF-M foi superior a volatilidade do CDI no período de 2000 a 2006. Os resultados constam na Tabela 9: 
Tabela 9: Teste-t - duas amostras para médias (IRF-M e CDI)

\begin{tabular}{lrr}
\hline & $I R F-M$ & \multicolumn{1}{c}{$C D I$} \\
\hline Média & 0,005024552 & 0,001613808 \\
Variância conhecida & 0,00000313 & 0,000000432 \\
Observações & 51 & 51 \\
Hipótese da diferença de média & 0 & \\
$\mathrm{t}$ & \multicolumn{2}{c}{12,91} \\
$\mathrm{P}(\mathrm{Z}<=\mathrm{z})$ uni-caudal & 0,00 \\
$\mathrm{z}$ crítico uni-caudal & 1,64 \\
$\mathrm{P}(\mathrm{Z}<=\mathrm{z})$ bi-caudal & \multicolumn{2}{c}{0,00} \\
$\mathrm{z}$ crítico bi-caudal & \multicolumn{3}{c}{1,96} \\
\hline
\end{tabular}

A hipótese nula de que as médias das duas séries sejam estatisticamente iguais não pode ser aceita e a diferença de médias entre ambas foi de 0,003411 , com um erro padrão de 0,000264 , o que resultou no seguinte intervalo de confiança a $95 \%$ :

\section{$0,003411 \pm 1,96 \times 0,000264=(0,003928 ; 0,002892)$}

Os resultados sugerem, então, que a volatilidade do IRF-M foi quase duas vezes maior que a volatilidade do CDI $(0,003411 \div 0,001613)$ durante o período de tempo estudado.

O resultado de que o IBOVESPA foi cerca de três vezes maior que o CDI no período de 1986 a 2006 e cerca de 47 vezes mais volátil no período de 2001 a 2006, deve-se exatamente ao fato da estabilização da economia pós Plano Real. Com a inflação controlada, a taxa nominal de juros da economia acompanhou essa estabilização e a volatilidade do CDI ficou mais "linearizada". O mercado de renda variável, mesmo diminuindo consideravelmente sua volatilidade com a estabilização da economia, continuou a oscilar de acordo com o mercado e variações internacionais, o que o tornou muito mais volátil que o CDI no período de tempo analisado de 2001 a 2006. Como o IRF-M possui retornos mais variáveis que o CDI e, portanto é mais volátil, sua média de volatilidade foi cerca de apenas 14 vezes menor que a média do mercado de ações. 


\subsection{Volatilidade dos Mercados - Modelo GARCH(1,1)}

\subsubsection{CDI e IBOVESPA}

Conforme mencionado na Metodologia (Capítulo 3) deste trabalho, os retornos do CDI utilizado para verificação do Modelo GARCH foram os retornos mensais reais, ou seja, foi descontada a inflação mensal (representada pelo IPC) dos retornos mensais do CDI, Figura 25.

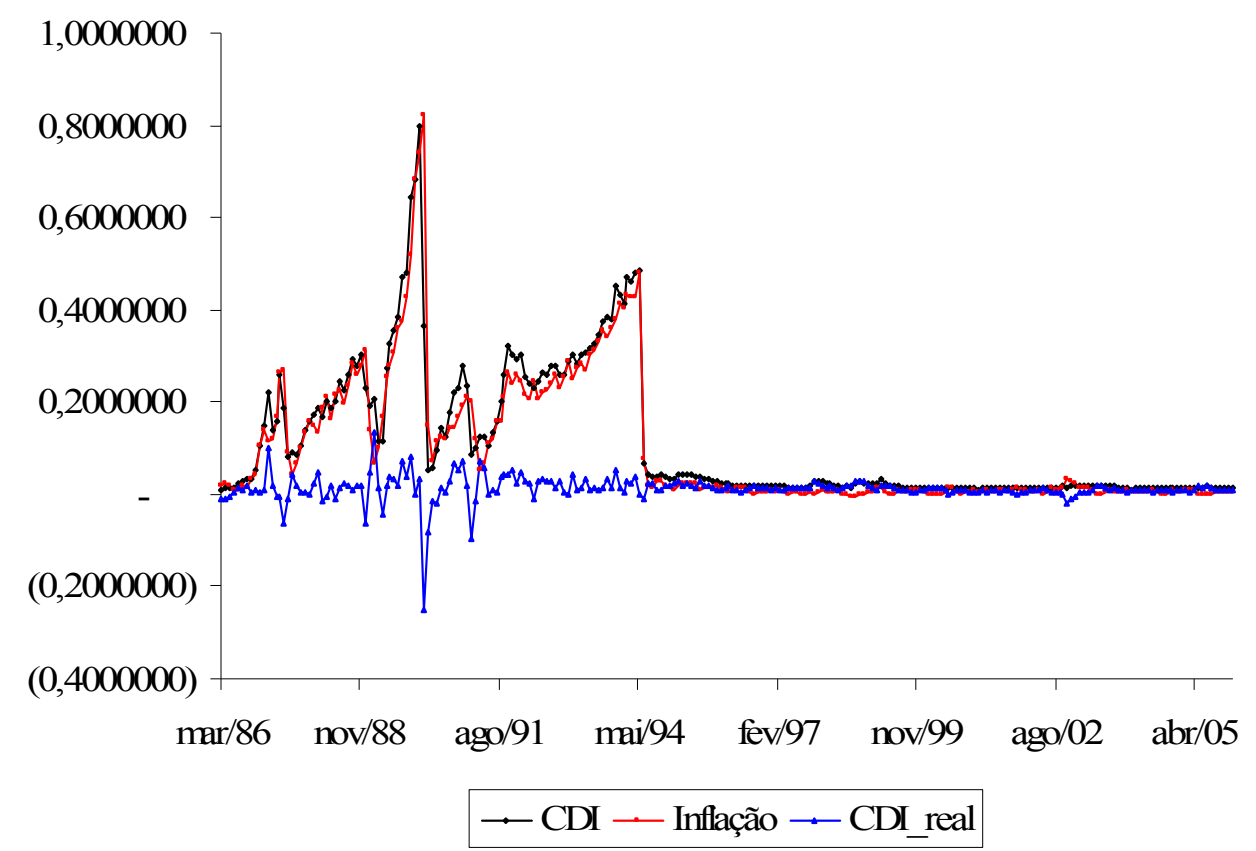

Figura 25: Retornos Mensais do CDI Real(de mar./86 a fev./2006).

Para iniciar os testes do modelo GARCH, é necessário conhecer se a variável, aqui no caso o CDI Real, possui raízes unitárias. De acordo com o teste $\mathrm{ADF},\left(\mathrm{H}_{0}\right.$ : há presença de raiz unitária), rejeita-se a hipótese nula, já que o valor do teste estatístico se encontra fora da área de 
aceitação da hipótese, de acordo com os valores críticos e seus respectivos níveis de significância descritos na Tabela 10 .

Tabela 10: Teste de Raiz Unitária - ADF - CDI Real

\begin{tabular}{|c|c|c|}
\hline \multicolumn{3}{|c|}{$\begin{array}{l}\text { Null Hypothesis: CDI_REAL has a unit root } \\
\text { Exogenous: Constant } \\
\text { Lag Length: } 0 \text { (Automatic based on SIC, MAXLAG=14) }\end{array}$} \\
\hline & & $\mathrm{t}$-Statistic \\
\hline \multicolumn{2}{|c|}{ Augmented Dickey-Fuller test statistic } & -11.75694 \\
\hline \multirow[t]{3}{*}{ Test critical values: } & $1 \%$ level & -3.457630 \\
\hline & $5 \%$ level & -2.873440 \\
\hline & $10 \%$ level & -2.573187 \\
\hline
\end{tabular}

*MacKinnon (1996) one-sided p-values.

No caso dos coeficientes da equação de um modelo $\operatorname{GARCH}(1,1)$, a soma dos coeficientes $\alpha$ e $\beta$ deve ser menor que 1, se os processos de retornos forem estacionários. Segundo Alexander (2005) é somente nesse caso que as estruturas a termo da volatilidade do modelo GARCH convergem para o nível médio de longo prazo da volatilidade. Nessa situação, os índices podem ser bem modelados por um modelo GARCH $(1,1)$.

Com a variável CDI Real, a soma dos coeficientes $\alpha$ e $\beta$ mostrou-se inferior a $1,(\alpha=$ 0.154946 e $\beta=0.814302$ ) sugerindo a estacionariedade dos processos e a modelagem pelo GARCH(1,1), Tabela 11. A estacionariedade dos processos sugere que a volatilidade passada pode ser um bom parâmetro para a estimativa da volatilidade futura. 
Tabela 11: Coeficientes da Equação do Modelo GARCH(1,1) - CDI Real

\begin{tabular}{|c|c|c|c|c|}
\hline \multicolumn{5}{|c|}{$\begin{array}{l}\text { Dependent Variable: CDI_REAL } \\
\text { Method: ML - ARCH (Marquardt) - Student's t distribution } \\
\text { Date: 09/04/07 Time: } 12: 22 \\
\text { Sample: } 1986 \text { M03 2006M02 } \\
\text { Included observations: } 240 \\
\text { Convergence achieved after } 16 \text { iterations } \\
\text { Variance backcast: ON } \\
\text { t-distribution degree of freedom parameter fixed at } 10 \\
\text { GARCH }=\mathrm{C}(2)+\mathrm{C}(3)^{*} \mathrm{RESID}(-1)^{\wedge} 2+\mathrm{C}(4)^{*} \mathrm{GARCH}(-1)\end{array}$} \\
\hline & Coefficient & Std. Error & z-Statistic & Prob. \\
\hline $\mathrm{C}$ & 0.010275 & 0.000465 & 22.11922 & 0.0000 \\
\hline \multicolumn{5}{|c|}{ Variance Equation } \\
\hline $\mathrm{C}$ & $1.63 \mathrm{E}-06$ & $9.47 \mathrm{E}-07$ & 1.725304 & 0.0845 \\
\hline $\operatorname{RESID}(-1)^{\wedge} 2$ & 0.154946 & 0.034339 & 4.512300 & 0.0000 \\
\hline GARCH(-1) & 0.814302 & 0.024980 & 32.59758 & 0.0000 \\
\hline R-squared & -0.006779 & Mean dependent var & & 0.012548 \\
\hline Adjusted R-squared & -0.019577 & S.D. dependent var & & 0.027666 \\
\hline S.E. of regression & 0.027936 & Akaike info criterion & & -5.785339 \\
\hline Sum squared resid & 0.184178 & Schwarz criterion & & -5.727329 \\
\hline Log likelihood & 698.2407 & Durbin-Watson stat & & 1.458665 \\
\hline
\end{tabular}

Como a série do CDI Real não se apresentou como uma distribuição normal, devido ao seu excesso de curtose (Kurtosis: 39,465) a mesma foi estimada em uma distribuição de Student.

A Tabela 12 evidencia que a série da variável CDI Real não apresentou autocorrelação serial nos resíduos, já que no teste $\mathrm{ARCH}$ - LM o valor da variável $\chi^{2}$ foi superior à variável $n \times R^{2}$, sendo $n$ o número de observações. 
Tabela 12: Teste dos Resíduos ARCH- LM - CDI Real

ARCH Test:

\begin{tabular}{llll}
\hline \hline F-statistic & 0.080334 & Probability & 0.777093 \\
Obs*R-squared & 0.080985 & Probability & 0.775968 \\
\hline \hline
\end{tabular}

A volatilidade calculada por meio do desvio padrão se mostrou muito similar a volatilidade do modelo $\operatorname{GRACH}(1,1)$ para o período que antecede a implementação do Plano Real. Uma melhor ilustração da comparação da volatilidade após o período mencionado encontra-se na Figura 26. Após julho de 1994, com a estabilização da economia, o modelo GARCH(1,1) pareceu capturar melhor a volatilidade dos retornos do CDI no período em relação à volatilidade calculada por meio do desvio padrão.

(a)

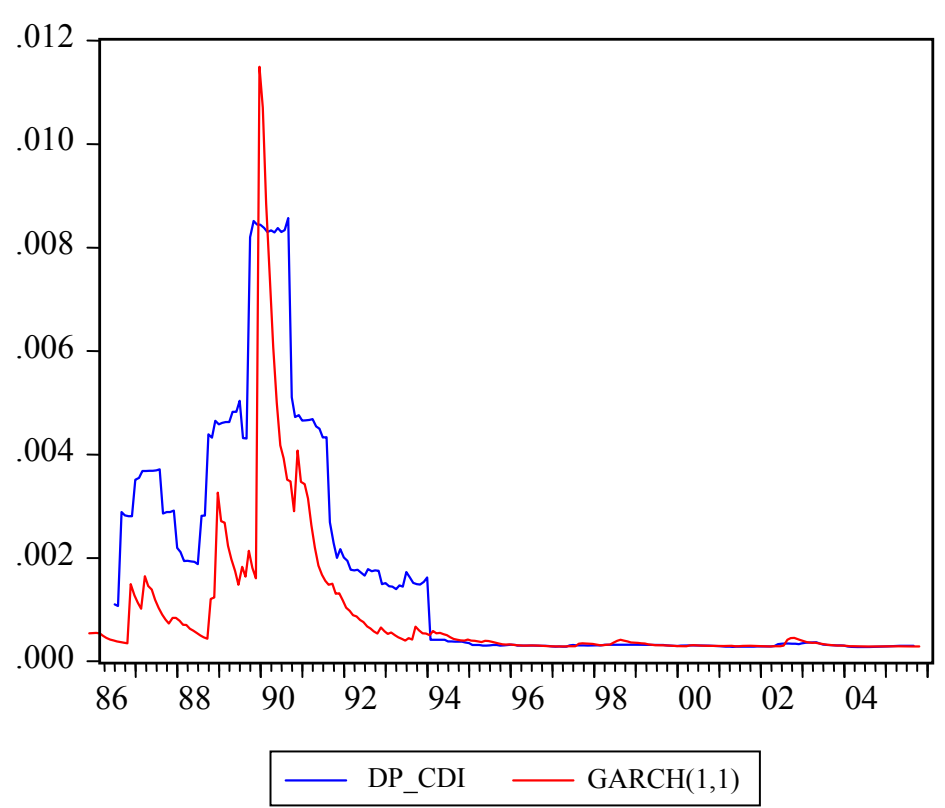


(b)

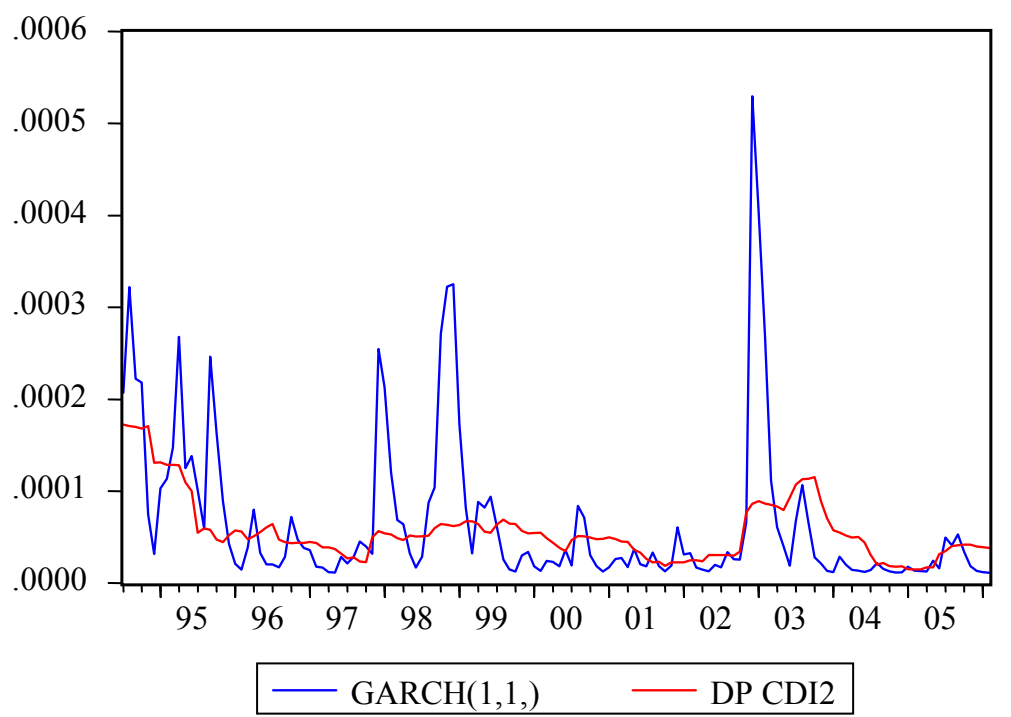

Figura 26: (a)Volatilidades GARCH(1,1) e Desvio Padrão CDI Real (de março de 1986 a fevereiro de 2006), (b) Volatilidades GARCH(1,1) e Desvio Padrão CDI Real (de julho de 1994 a fevereiro de 2006).

Conforme também especificado na Metodologia (Capítulo 3) deste trabalho, o modelo GARCH(1,1) para o IBOVESPA foi calculado a partir de seus retornos diários, porém, para efeito de comparação dos mercados de renda fixa e renda variável e melhor visualização dos picos de volatilidade de ambos, calculou-se a volatilidade $\operatorname{GARCH}(1,1)$ do IBOVESPA para os retornos mensais de modo a permitir sua comparação ao CDI.

De acordo com a Figura 27, observa-se uma grande alta na volatilidade dos dois mercados entre 1989 e 1991, conforme já era esperado devido aos resultados encontrados e explicados no cálculo das volatilidades por meio dos desvios padrão anuais (Capítulo 4, item 4.1). 

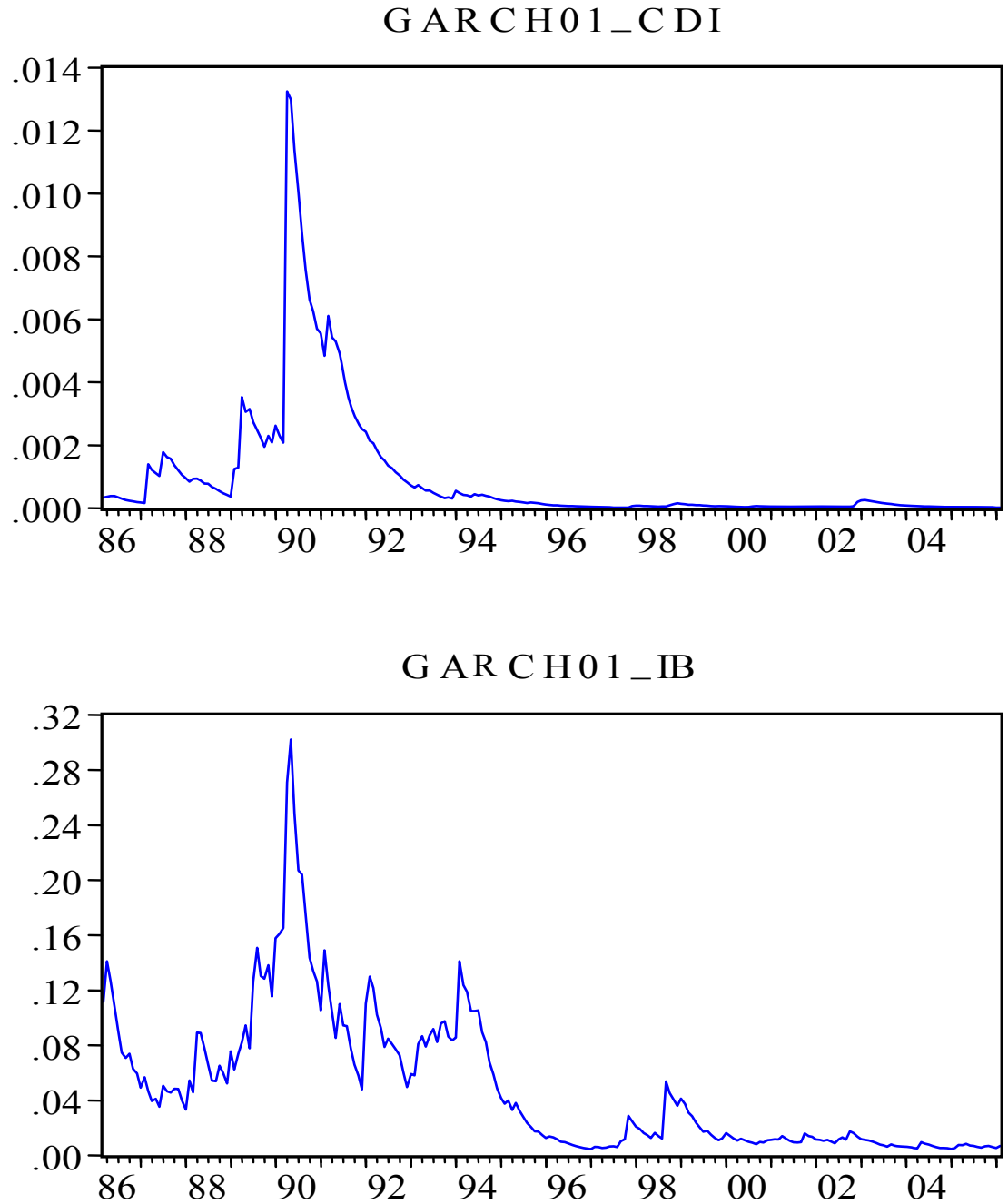

Figura 27: (a)Volatilidade GARCH(1,1) CDI Real (de março de 1986 a fevereiro de 2006) e (b) IBOVESPA.

A volatilidade $\operatorname{GARCH}(1,1)$ do IBOVESPA dos retornos mensais também foi comparada à volatilidade calculada por meios dos desvios padrão anuais e observou-se padrão comportamental muito semelhante durante o período estudado, conforme apresentado pela Figura 28. 


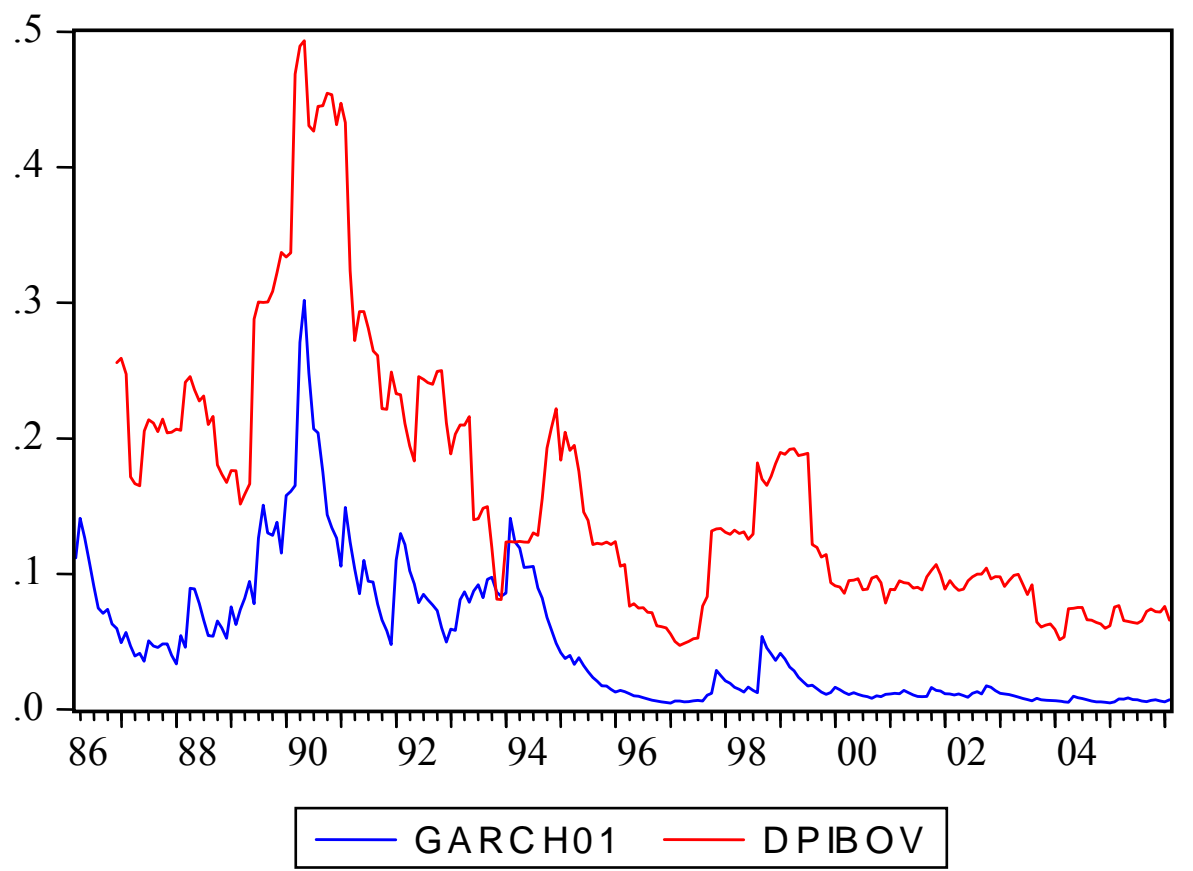

Figura 28: Volatilidades GARCH(1,1) e Desvio Padrão IBOVESPA (de março de 1986 a fevereiro de 2006).

Os resultados dos testes referentes ao modelo $\operatorname{GARCH}(1,1)$ para os retornos diários do IBOVESPA constam nas Tabelas 13, 14 e 15.

No teste ADF, sob a hipótese nula de que há a presença de raiz unitária, os resultados para os três níveis de significância rejeitaram $\mathrm{H}_{0}$, já que o valor do teste ficou acima dos valores críticos para a série da variável IBOVESPA, Tabela 13. 
Tabela 13: Teste de Raiz Unitária - ADF - IBOVESPA

Null Hypothesis: IBOVESPA has a unit root

Exogenous: Constant

Lag Length: 1 (Automatic based on SIC, MAXLAG=32)

\begin{tabular}{lccc}
\hline \hline & & & \\
& & t-Statistic & Prob.* \\
\hline \hline Augmented Dickey-Fuller test statistic & -44.45771 & 0.0000 \\
\hline Test critical values: & $1 \%$ level & -3.431454 & \\
& $5 \%$ level & -2.861913 & \\
& $10 \%$ level & -2.567011 & \\
\hline \hline
\end{tabular}

*MacKinnon (1996) one-sided p-values.

A soma dos coeficientes $\alpha$ e $\beta$ para a variável IBOVESPA também foi inferior a 1 $(\alpha=0,125542$ e $\beta=0,863354)$, o que comprova a estacionariedade dos processos e a convergência dos dados a um modelo GARCH(1,1), Tabela 14. A estacionariedade do processo da série do IBOVESPA leva a crer que a volatilidade passada do IBOVESPA pode ser um bom indicador de sua volatilidade futura. 
Tabela 14: Coeficientes da Equação do Modelo GARCH(1,1) - IBOVESPA

Dependent Variable: IBOVESPA

Method: ML - ARCH (Marquardt) - Normal distribution

Date: 09/03/07 Time: 15:43

Sample: 3/06/1986 11/06/2006

Included observations: 5091

Convergence achieved after 14 iterations

Variance backcast: ON

$\mathrm{GARCH}=\mathrm{C}(2)+\mathrm{C}(3)^{*} \mathrm{RESID}(-1)^{\wedge} 2+\mathrm{C}(4)^{*} \mathrm{GARCH}(-1)$

\begin{tabular}{|c|c|c|c|c|}
\hline & Coefficient & Std. Error & z-Statistic & Prob. \\
\hline $\mathrm{C}$ & 0.002775 & 0.000315 & 8.812665 & 0.0000 \\
\hline \multicolumn{5}{|c|}{ Variance Equation } \\
\hline $\mathrm{C}$ & $8.20 \mathrm{E}-06$ & $1.41 \mathrm{E}-06$ & 5.801441 & 0.0000 \\
\hline $\operatorname{RESID}(-1)^{\wedge} 2$ & 0.125542 & 0.006405 & 19.60084 & 0.0000 \\
\hline GARCH(-1) & 0.863354 & 0.006430 & 135.8312 & 0.0000 \\
\hline R-squared & -0.004011 & \multicolumn{2}{|c|}{ Mean dependent var } & 0.004903 \\
\hline Adjusted R-squared & -0.004603 & \multicolumn{2}{|c|}{ S.D. dependent var } & 0.033605 \\
\hline S.E. of regression & 0.033682 & \multicolumn{2}{|c|}{ Akaike info criterion } & -4.356474 \\
\hline Sum squared resid & 5.771005 & \multicolumn{2}{|c|}{ Schwarz criterion } & -4.351339 \\
\hline Log likelihood & 11093.40 & \multicolumn{2}{|c|}{ Durbin-Watson stat } & 1.710669 \\
\hline
\end{tabular}

A Tabela 15 evidencia que a série do IBOVESPA também não apresentou heterocedasticidade dos resíduos, já que no teste $\mathrm{ARCH}-\mathrm{LM}$ o valor da variável $\chi^{2}$ foi superior à variável $n \times R^{2}$, sendo $n$ o número de observações.

Tabela 15: Teste de Resíduos - ARCH-LM - IBOVESPA

\begin{tabular}{llll}
\hline \hline ARCH Test: & & & \\
\hline \hline F-statistic & 0.194387 & Probability & 0.659309 \\
Obs*R-squared & 0.194456 & Probability & 0.659233 \\
\hline \hline
\end{tabular}


A figura 29 compara a volatilidade por meio do desvio padrão e a volatilidade GARCH $(1,1)$ dos retornos diários da série do IBOVESPA. Assim como para os retornos mensais, a volatilidade dos retornos diários foi bem similar quando comparados os dois modelos. Para que a volatilidade por meio do desvio padrão se apresentasse na mesma escala que a do modelo GARCH(1,1), os desvios padrão mensais dos retornos diários foram todos divididos por 10.

Já que as volatilidades calculadas das duas formas foram bem similares, e os picos se deram nos mesmos períodos, as possíveis causas estão explicadas no capítulo 4, item 4.2.

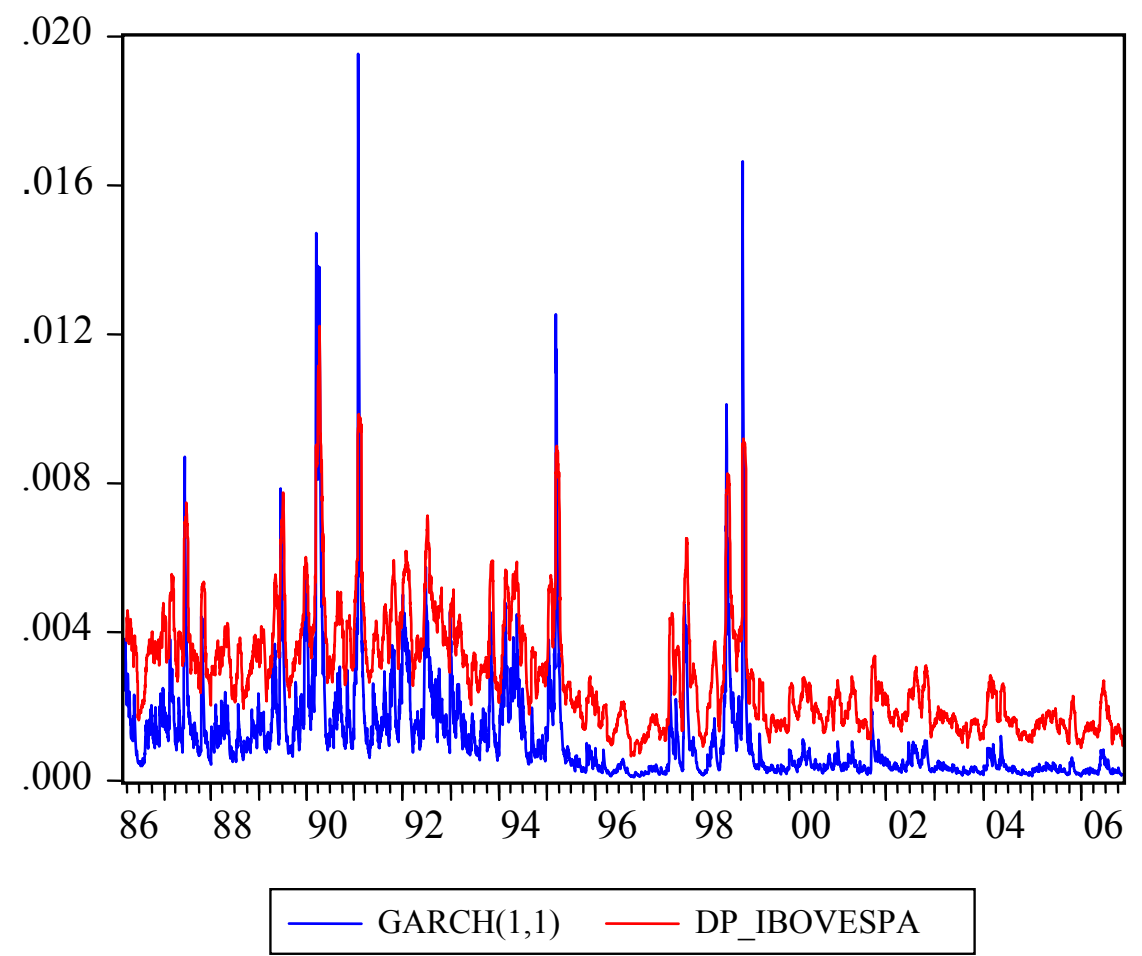

Figura 29: Volatilidades GARCH e Desvio Padrão IBOVESPA (de março de 1986 a fevereiro de 2006). 


\subsubsection{IRF-M e IBOVESPA}

O teste de raiz unitária realizado para os dois indicadores (do mercado de renda fixa, IRFM, e de renda variável, IBOVESPA), para o período de dezembro de 2000 , rejeitou a hipótese nula da existência de raiz unitária, conforme mostra os valores críticos apresentados na Tabela 16 (a) e (b):

Tabela 16(a) e (b): Teste de Raiz Unitária - ADF - IRF-M e IBOVESPA, respectivamente.

(a) Null Hypothesis: IBOV has a unit root Exogenous: Constant

Lag Length: 0 (Automatic based on SIC, MAXLAG=22)

\begin{tabular}{lrrr}
\hline \hline & t-Statistic & Prob.* \\
\hline \hline Augmented Dickey-Fuller test statistic & -34.86136 & 0.0000 \\
\hline Test critical values: & $1 \%$ level & -3.435169 & \\
& $5 \%$ level & -2.863556 & \\
& $10 \%$ level & -2.567893 & \\
\hline \hline
\end{tabular}

*MacKinnon (1996) one-sided p-values.

(b) Null Hypothesis: IRFM has a unit root

Exogenous: Constant

Lag Length: 1 (Automatic based on SIC, MAXLAG=22)

\begin{tabular}{lccc}
\hline \hline & t-Statistic & Prob.* \\
\hline \hline Augmented Dickey-Fuller test statistic & -28.51076 & 0.0000 \\
\hline Test critical values: & $1 \%$ level & -3.435176 & \\
& $5 \%$ level & -2.863559 & \\
& $10 \%$ level & -2.567894 & \\
\hline \hline
\end{tabular}

*MacKinnon (1996) one-sided p-values. 
A Tabela 17 (a) e (b) evidencia as equações dos modelos $\operatorname{GARCH}(1,1)$ estimados para os retornos diários do IRF-M e IBOVESPA, respectivamente. Devido ao excesso de curtose apresentado pela série do IRF-M (Kurtosis: 35,33), o modelo GARCH, para esse indicador, foi calculado por meio de uma distribuição de Student.

Os resultados encontrados sugerem que as duas séries são estacionárias, já que a soma de seus coeficientes $\alpha$ e $\beta$ e foi inferior a 1 (IBOVESPA: $\alpha=0,0457$ e $\beta=0,929950$; IRFM: $\alpha=0,2755$ e $\beta=0,6999$ ).

Tabela 17: (a) Coeficientes estimados das equações de um modelo GARCH(1,1) - séries de retorno IBOVESPA, (b) IRF-M.

(a) Dependent Variable: IBOV

Method: ML - ARCH (Marquardt) - Normal distribution

Date: 09/05/07 Time: 11:11

Sample: 12/04/2000 3/01/2006

Included observations: 1301

Convergence achieved after 10 iterations

Variance backcast: ON

$\mathrm{GARCH}=\mathrm{C}(2)+\mathrm{C}(3) * \mathrm{RESID}(-1)^{\wedge} 2+\mathrm{C}(4) * \mathrm{GARCH}(-1)$

\begin{tabular}{|c|c|c|c|c|}
\hline & Coefficient & Std. Error & z-Statistic & Prob. \\
\hline $\mathrm{C}$ & 0.001362 & 0.000499 & 2.730946 & 0.0063 \\
\hline \multicolumn{5}{|c|}{ Variance Equation } \\
\hline $\mathrm{C}$ & 7.77E-06 & $2.60 \mathrm{E}-06$ & 2.994961 & 0.0027 \\
\hline $\operatorname{RESID}(-1)^{\wedge} 2$ & 0.045736 & 0.009656 & 4.736462 & 0.0000 \\
\hline GARCH(-1) & 0.929950 & 0.014169 & 65.63429 & 0.0000 \\
\hline R-squared & -0.000408 & \multicolumn{2}{|c|}{ Mean dependent var } & 0.000991 \\
\hline Adjusted R-squared & -0.002722 & \multicolumn{2}{|c|}{ S.D. dependent var } & 0.018342 \\
\hline S.E. of regression & 0.018367 & \multicolumn{2}{|c|}{ Akaike info criterion } & -5.209584 \\
\hline Sum squared resid & 0.437529 & \multicolumn{2}{|c|}{ Schwarz criterion } & -5.193686 \\
\hline Log likelihood & 3392.834 & \multicolumn{2}{|c|}{ Durbin-Watson stat } & 1.933350 \\
\hline
\end{tabular}


(b)Dependent Variable: IRFM

Method: ML - ARCH (Marquardt) - Student's t distribution

Date: 09/05/07 Time: 11:21

Sample: $12 / 04 / 2000$ 3/01/2006

Included observations: 1300

Convergence achieved after 20 iterations

Variance backcast: ON

$\mathrm{t}$-distribution degree of freedom parameter fixed at 10

$\mathrm{GARCH}=\mathrm{C}(2)+\mathrm{C}(3) * \mathrm{RESID}(-1)^{\wedge} 2+\mathrm{C}(4) * \mathrm{GARCH}(-1)$

\begin{tabular}{|c|c|c|c|c|}
\hline & Coefficient & Std. Error & z-Statistic & Prob. \\
\hline $\mathrm{C}$ & 0.000762 & $1.59 \mathrm{E}-05$ & 48.06937 & 0.0000 \\
\hline \multicolumn{5}{|c|}{ Variance Equation } \\
\hline $\mathrm{C}$ & $2.66 \mathrm{E}-08$ & $4.51 \mathrm{E}-09$ & 5.903652 & 0.0000 \\
\hline $\operatorname{RESID}(-1)^{\wedge} 2$ & 0.275597 & 0.029468 & 9.352330 & 0.0000 \\
\hline GARCH(-1) & 0.699997 & 0.022329 & 31.34888 & 0.0000 \\
\hline R-squared & -0.000189 & \multicolumn{2}{|c|}{ Mean dependent var } & 0.000743 \\
\hline Adjusted R-squared & -0.002504 & \multicolumn{2}{|c|}{ S.D. dependent var } & 0.001347 \\
\hline S.E. of regression & 0.001349 & \multicolumn{2}{|c|}{ Akaike info criterion } & -11.48762 \\
\hline Sum squared resid & 0.002357 & \multicolumn{2}{|c|}{ Schwarz criterion } & -11.47172 \\
\hline Log likelihood & 7470.955 & \multicolumn{2}{|c|}{ Durbin-Watson stat } & 2.085248 \\
\hline
\end{tabular}

A Tabela 18 evidencia, através do teste de resíduos ARCH-LM, que nenhuma das duas séries possuem heterocedasticidade dos resíduos, já que no teste $\mathrm{ARCH}$ - LM o valor da variável $\chi^{2}$ foi superior à variável $n \times R^{2}$, sendo $n$ o número de observações. 
Tabela 18: Teste de Resíduos ARCH-LM - IBOVESPA e IRF-M

IBOVESPA

ARCH Test:

\begin{tabular}{llll}
\hline \hline F-statistic & 0.409345 & Probability & 0.522415 \\
Obs*R-squared & 0.409846 & Probability & 0.522048 \\
\hline \hline & & & \\
IRF-M & & & \\
ARCH Test: & & & 0.943295 \\
\hline \hline F-statistic & 0.005061 & Probability & 0.943240 \\
Obs*R-squared & 0.005069 & Probability & \\
\hline \hline
\end{tabular}

A Figura 30 demonstra a volatilidade dos retornos do IRF-M para o período de tempo analisado, calculada por meio dos desvios padrão contínuos e do modelo $\operatorname{GARCH}(1,1)$, respectivamente. De modo a permitir uma melhor comparação das volatilidades, o desvio padrão dos retornos do IRF-M, foi dividido por 100, para que se enquadrasse na mesma escala do modelo GARCH(1,1).

Como é possível observar, o comportamento da volatilidade do IRF-M, calculada por meio dos desvios padrão contínuos e do modelo $\operatorname{GARCH}(1,1)$, é muito similar durante todo o período de tempo analisado, porém, o modelo $\operatorname{GARCH}(1,1)$ pareceu capturar melhor alguns picos de volatilidade do Índice de Renda Fixa do que o desvio padrão, conforme observa-se por exemplo no segundo semestre de 2003. 


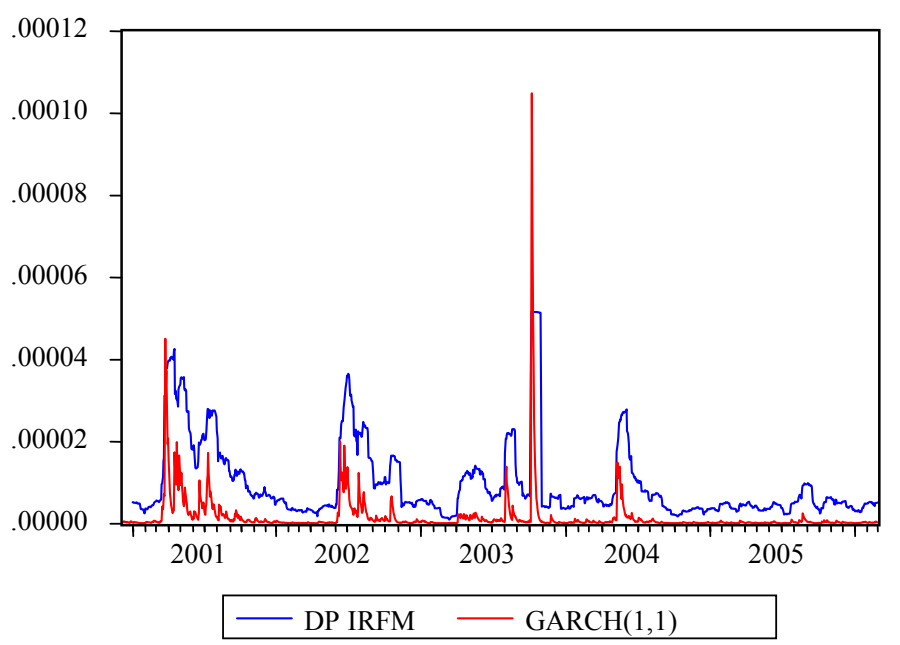

Figura 30: Volatilidades Desvio Padrão e GARCH(1,1)-IRF-M (dez./01 a dez./06).

A volatilidade dos retornos diários do IBOVESPA também foi calculada por meio dos desvios padrão contínuos e do modelo $\operatorname{GARCH}(1,1)$, como mostra a Figura 31, respectivamente. Assim como no caso do IRF-M, para uma melhor comparação das volatilidades, o desvio padrão dos retornos do IBOVESPA, calculado por meio dos desvios padrão contínuos, foi dividido por 100, para que fosse apresentado na mesma escala do modelo $\operatorname{GARCH}(1,1)$.

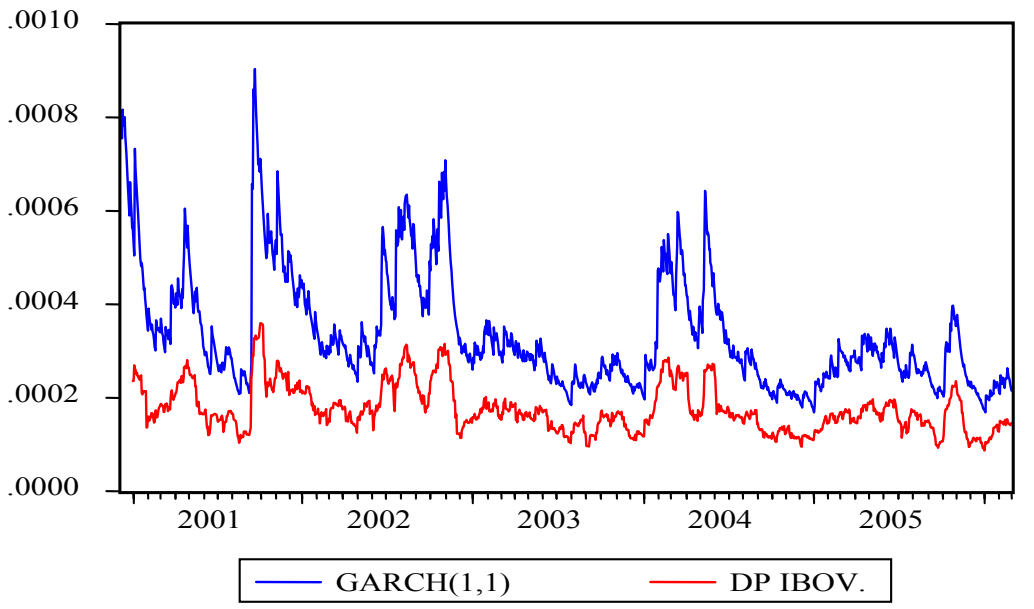

Figura 31: Volatilidades Desvio Padrão e GARCH(1,1) - IBOVESPA (dez./01 a dez./06) 
Da mesma maneira que para o caso do Índice de Renda Fixa de Mercado, o comportamento da volatilidade do IBOVESPA, calculada por meio dos desvios padrão contínuos e do modelo $\operatorname{GARCH}(1,1)$, é muito similar durante todo o período de tempo analisado, e da mesma maneira, o modelo GARCH, pareceu capturar os picos de volatilidade de forma mais eficaz.

Comparando-se os dois gráficos através das Figuras 30 e 31, observa-se que nos anos de 2001 e 2002 os dois mercados apresentaram picos parecidos em suas volatilidades. O mercado de renda variável, por exemplo, exibe um grande pico em sua volatilidade em meados do primeiro semestre de 2001 (que pode ter sido provocado pela crise energética), o que também é observado na volatilidade do IRF-M, conforme mencionado anteriormente.

Um maior pico no IBOVESPA acontece logo após 11 de setembro de 2001(data dos atentados terroristas nos EUA) que se estende durante todo aquele mês. Como a Figura 30 exibe apenas o período do início de 2001 ao início de 2006, esse aumento na volatilidade torna-se mais evidente do que em figuras anteriores, onde era apresentado todo o período de 1986 a 2006.

Tanto na análise da volatilidade calculada por meio dos desvios padrão dos retornos, quanto do modelo GARCH(1,1), a hipótese nula da Hipótese 1 deste trabalho não pode ser aceita em favor da aceitação da hipótese alternativa, pois, ao se comparar o IBOVESPA com os dois benchmark do mercado de renda fixa (CDI e IRF-M), verificou-se picos coincidentes de volatilidade entre os dois mercados em diversos momentos durante o período de tempo analisado.

A Hipótese 2, que relaciona o padrão comportamental da volatilidade dos mercados antes e depois da implantação do Plano Real, também se tornou evidente na volatilidade calculada por meio do modelo $\operatorname{GARCH}(1,1)$, já que rejeitamos, da hipótese nula em favor da hipótese alternativa, de que houve mudança considerável no padrão de comportamento da volatilidade dos dois mercados, antes e depois do Plano Real. 
No que tange a relação entre as duas volatilidades ao longo do tempo, a hipótese alternativa da Hipótese 3 deste trabalho foi rejeitada em favor da hipótese nula, já que as relações entre as volatilidades dos dois mercados não forma estáveis no período de tempo analisado.

\section{$5 \quad$ Considerações Finais}

Este trabalho buscou analisar as volatilidades dos mercados de renda fixa e variável do Brasil, ao longo do período 1986-2006, considerando todos os planos econômicos implantados no país nesse período.

Esta pesquisa procurou reproduzir para o mercado brasileiro o estudo dos autores Reilly, Wright e Chan (2000), que verificaram a volatilidade dos mercados de renda fixa e variável nos EUA e de Young e Johnson $(2002,2004,2005)$, que replicaram a pesquisa dos autores americanos em países europeus: Reino Unido, Suíça e Alemanha.

O estudo ainda apresentou três objetivos específicos: comparar os picos de volatilidade e verificar se houve picos coincidentes nas volatilidades dos dois mercados; analisar se houve mudança no padrão de comportamento das volatilidades antes e depois do Plano Real e por fim, verificar se a relação entre as volatilidades dos dois mercados foi estável ao longo do período estudado.

Para tal análise foram utilizados indicadores dos dois mercados. Para o mercado de renda fixa, os retornos do CDI (Certificado de Depósito Interfinanceiro), de março de 1986 a fevereiro de 2006 e os retornos do IRF-M (Índice de Renda Fixa de Mercado), de dezembro de 2000 a dezembro de 2006. Como indicador do mercado de ações, os retornos do IBOVESPA (Índice da 
BOVESPA), sendo a série iniciada em março de 1986 para efeito de comparação com os dois mercados.

Primeiramente foi efetuada a comparação entre as volatilidades dos retornos mensais do CDI com o IBOVESPA e, em seguida, as volatilidades dos retornos mensais do IRF-M com os outros dois indicadores, de acordo com os diferentes períodos de tempo estudados.

Dos resultados encontrados, nove entre as dez maiores volatilidades calculadas pelos desvios padrão discretos, foram coincidentes para as duas classes de ativos (CDI e IBOVESPA), portanto a hipótese nula da Hipótese 1 deste trabalho, foi rejeitada em favor da hipótese alternativa, de que os dois mercados possuem picos coincidentes de volatilidade. Nenhum dos estudos anteriores, tanto do mercado estadunidense, quanto do mercado europeu, obtiveram resultados semelhantes ao mercado brasileiro para essa hipótese, já que nos mercados internacionais citados não houve coincidência temporal entre as volatilidades dos mercados de renda fixa e variável.

Os resultados sugerem que a volatilidade do mercado acionário brasileiro foi cerca de três vezes maior que o mercado de renda fixa em um período de vinte anos, quando comparado o CDI ao IBOVESPA (resultado semelhante aos encontrados pelos autores Reilly, Wright e Chan (2000) no mercado americano e Young e Johnson (2005) no mercado Alemão).

Mas num período que compreendeu seis anos (2000 a 2006), a volatilidade do IBOVESPA se mostrou 47 vezes mais volátil que o CDI e 14 vezes mais volátil que o IRF-M. Isso se deve ao fato de que quando comparado, durante os vinte anos analisados, o CDI, antes do Plano Real, apresentou uma volatilidade muito alta e muito similar ao mercado de ações, por esse motivo ao longo de todo o tempo, a diferença entre as duas volatilidades diminui. Entretanto, após a estabilização da economia, que é o período analisado na segunda parte do estudo, o mercado de ações se mostra menos volátil que antes da implantação do Plano Real, porém 
mantém uma volatilidade bem mais alta que a do mercado de renda fixa, (que com a queda da inflação trouxe a queda da taxa de juros), o que diferenciou muito as duas volatilidades.

Os maiores picos de volatilidade entre os mercados, quando comparados o CDI ao IBOVESPA, ocorreram anteriormente à implantação definitiva do Plano Real, ou seja, antes de 1994, já que os planos econômicos adotados no país na segunda metade da década de oitenta e início da década de noventa não foram capazes de conter a aceleração inflacionária e nem a alta nas taxas de juros.

Portanto, devido a grande diferença na média de volatilidade dos dois mercados e ao fato dos maiores picos terem sido observados antes do Plano Real, rejeitamos a hipótese nula da Hipótese 2, em favor da hipótese alternativa, pois houve mudança considerável no padrão de volatilidade das duas classes de ativos após a implantação do Plano Real, em 1994.

No que se refere ao relacionamento das volatilidades dos dois mercados, a razão entre as volatilidades dos retornos do CDI e do IBOVESPA registrou que a relação não é estável ao longo do tempo devido ao grande intervalo encontrado na escala gráfica, o que não permitiu rejeitar a hipótese nula da Hipótese 3 (A relação entre as volatilidades das duas classes de ativos ao longo de todo o período estudado não é estável). Os resultados para essa hipótese foram semelhantes aos resultados encontrados nos mercados dos EUA, Alemanha, Suíça e Reino Unido, pois em nenhum desses estudos a relação das volatilidades dos mercados de renda fixa e variável foi estável ao longo do tempo.

Em relação ao risco sistemático, o maior coeficiente beta $(\beta)$ encontrado entre os mercados (para os indicadores CDI e IBOVESPA) foi no ano de 1994, e desse ano até o início do ano seguinte houve um aumento muito considerável do risco sistemático entre os dois mercados, o qual foi aparentemente equilibrado após a implantação definitiva do Plano Real. 
A análise da volatilidade dos retornos do IRF-M sugere que a maior parte dos picos de volatilidade ocorreu em alguns meses de 2002 e 2004. Em 2002, principalmente a partir do segundo semestre, ocorreu certa instabilidade econômica no Brasil, provocada principalmente pela proximidade das eleições presidenciais.

Pelos resultados expostos, essa instabilidade estendeu-se também ao mercado financeiro, elevando a volatilidade dos ativos, já que o IBOVESPA também apresentou as maiores volatilidades (no período de 2001 a 2006), no ano de 2002. A razão entre as volatilidades dos retornos do IRF-M e do IBOVESPA parece não ser estável ao longo do tempo dado que a variação da razão foi de 0,0266 a 0,1046 , mas ainda assim essa relação se mostrou menos instável do que quando comparado o CDI ao IBOVESPA.

A correlação entre os mercados sugere que a volatilidade do IRF-M e do IBOVESPA estão se tornando cada vez mais positivas, já que a linha de tendência do gráfico de correlação se mostrou ascendente. Resultado contrário foi encontrado quando comparado o CDI ao IBOVESPA, em que a linha de tendência foi negativa.

Uma fonte de explicação para o fenômeno observado seria que o IRF-M é mais sensível às mudanças na economia e no mercado por ser uma carteira de títulos pré-fixados, do que o CDI, que é pós-fixado. Por esse motivo seus retornos se apresentam de forma mais variável, o que os assemelha ao mercado de ações, embora sejam títulos do mercado de renda fixa.

A volatilidade calculada por meio do modelo $\operatorname{GARCH}(1,1)$ se mostrou muito semelhante a volatilidade calculada por meio dos desvios padrão para os três ativos analisados, porém o modelo $\operatorname{GARCH}(1,1)$ pareceu capturar de maneira mais eficaz os picos de volatilidade dos indicadores do mercado de renda fixa. As três séries se mostraram estacionárias e convergiram bem ao modelo $\operatorname{GARCH}(1,1)$, já que em todos os casos a soma dos coeficientes $\alpha$ e $\beta$ nas equações do modelo foram inferiores a 1 . 
Os resultados encontrados neste trabalho, antes e depois da implantação definitiva do Plano Real, sugerem que as oscilações nas variáveis macroeconômicas, como taxa de juros, inflação e crescimento, acabam por causar incertezas nos investidores do mercado financeiro e conseqüentemente nos preços dos ativos. Sugere-se assim, que trabalhos futuros estudem mais profundamente essa relação, analisando a correlação entre as séries das variáveis econômicas com os preços dos ativos.

Por fim, espera-se que este trabalho tenha contribuído de maneira significativa para o estudo da volatilidade do mercado financeiro e que auxilie gestores de portfólios, investidores e pesquisadores em seus trabalhos futuros. 


\section{Referências Bibliográficas}

ALEXANDER, C. Modelos de mercado: um guia para análise de informações financeiras. São Paulo: BM\&F, 2005.

AVERBUG, M. Plano Cruzado: Crônica de uma Experiência. Revista do BNDES. Rio de Janeiro, V. 12, N. 24, P. 211-240, Dezembro, 2005.

BATISTA JR., P. N. O Plano Real à luz da experiência mexicana e argentina. Estudos Avançados. V.10. N.28. São Paulo Setembro - Dezembro, 1996.

BRESSER-PEREIRA, L.C. Alógica perversa da estagnação: dívida, déficit e inflação no Brasil. Revista Brasileira de Economia. Vol 45 (2), p.p. 187-211. Abril, 1991.

BRESSER-PEREIRA, L.C. Macroeconomia do Brasil pós-1994. Textos para discussão n. 131. São Paulo, EESP/ FGV. Setembro, 2003.BRESSER-PEREIRA, L.C. Pronunciamento na Câmara dos Deputados, 1987. Disponível em: http://www.bresserpereira.org.br/. Acesso em 20/12/2006.

CALDERON, P., FONTES, R. Credibilidade e Mercado Secundário da Dívida Externa Brasileira. Revista de Análise Econômica da Faculdade de Ciências Econômicas da UFRGS. Edição 30. Ano 16, setembro de 1998.

CARVAlHO, C.E. Origem e gênese do Plano Collor. Revista Nova Economia. V. 16, N. 1. Janeiro - Abril, 2006.

CERETTA, P.S., COSTA JR., N.C.A.C. Influência dos eventos negativos e positivos sobre a volatilidade dos mercados da América latina. Cadernos de Pesquisa em Administração, São Paulo, vol. 1. n. 103, (3º. Trimestre/1999).

DARIO, A.D.G. Apreçamento de ativos baseados em volatilidade: swaps de volatilidadevariância em um modelo de Heston. Resenha da BM\&F, n. 164. Disponível em:http://www.bmf.com.br/2004/pages/instituto/publicacoes/resenha/arquivos/164/artigo02.pdf. Acesso em: 18/08/2006.

ENDERS, W. Applied Econometric Time Series. Iowa State University: John Wiley \& Sons, Inc: 2004. 
ENGLE, R. F. Autoregressive conditional heteroscedasticity with estimates of the variance of united kingdom inflation . Econometrica. Vol. 50, No. 4 (Jul., 1982), pp. 987-1008

FABOZZI, F. Mercado, análise e estratégia de bônus. Rio de Janeiro: Qualitymark, 2000.

FERNADES, A.J., PAIS, C. A Economia Brasileira na Década de 80: conseqüências da crise da dívida externa, inflação e crise do Estado. Disponível em:

http://www2.egi.ua.pt/XXIIaphes/Artigos/a\%20Fernandes\%20onInflama\%c3\%a7\%c3\%a3o.PDF Acesso em 01/12/2006.

FERNANDES, M.; MOTA, B.S. Desempenho dos Estimadores de Volatilidade da Bolsa de Valores de São Paulo. Revista Brasileira de Economia. Rio de Janeiro.Jul/Set 2004. pp 429448.

FISHER, I. LORIE, J.H. Some studies on variability of returns on investments in common stock. The Journal of Business, vol. 43,n. 2 (Apr., 1970), pp. 99-134.

GABE, J. ;PORTUGAL, M.S. Volatilidade Implícita X Volatilidade Estatística: Uma avaliação para o mercado brasileiro a partir de dados de ações e opções da Telemar S.A. Disponível em: http://www.ufrgs.br/ppge/pcientifica/2003 11.pdf. Acesso em 25/10/06.

GOEU, P.; MARQUERING, W. Modeling the condicional variance between bonds and stock returns: a multivariate GRACH approach. Journal of Financial Econometrics. V.2. N. 4. pp 531- 564. 2004.

GREMAUD, A. P; VASCONCELOS, M. A. S.; TONETO JR, R. Economia Brasileira e Contemporânea. 5.ed. São Paulo, Atlas, 2004.

GUJARATI, D.N. Econometria Básica. 3 ed. São Paulo: Pearson Makron Books, 2000.

JONES, C. P.; WILSON, Jack W. Is stock price volatility increasing? Financial Analyst Journal; vol. 45, n.6; ;(Nov/Dec 1989) pg. 20.

JORION, P. The long-term risks of global stock markets. Financial Management; vol. 32, n.4;(Winter 2003);pg. 5.

LONGSTAFF, F.A.; SCHARTZ, E. S. Interest rate volatility and bond prices. Financial Analysts Journal.; vol. 49, n.4 (Jul/Aug 1993); pg. 70

MARÇAL. E.F. Ensaios sobre Eficiência, cointregração, componentes comuns, não linearidades na variância dos mercados financeiros: um estudo da estrutura a termo das taxas de juros e da volatilidade de títulos da dívida externa. Tese de Doutorado. FEA/USP. São Paulo, 2004. 
MORAIS, I.A.C.; PORTUGAL, M.S. Modelagem e previsão da volatilidade determinística e estocástica para a série do IBOVESPA. Texto para discussão - PPGE/ UFRGS. 1999. N.3.

OFFICER, R.R. The variability of the market factor of the New York Exchange. The Journal of Business. Vol.46, n.3 (Jul., 1973). pp $434-453$.

OMETTO, A.N.H., FORTUOSO, M.C.O., SILVA, M.V. Economia brasileira na década de oitenta e seus reflexos nas condições de vida da população. Revista de Saúde Pública. 29/5. pp 403-14. 1995.

PIO, C. A estabilização heterodoxa no Brasil: idéias e redes políticas. Revista Brasileira de Ciências Sociais. V.16, N.46. Junho, 2001.

RAMALHO, R.M.; SECURATO, J.R.; SILVEIRA, H. P. O que há de errado com o mercado acionário brasileiro? Comparação entre os retornos médios do IBOVESPA e do CDI no período de 1986 a 2004. SEMEAD - Seminários em Administração. VII. Anais.... São Paulo, 2004.

REILLY, F.K.,CHAN, K.C., WRIGHT, D.J. Bond market volatility compared to stock market volatility. Journal of Portfolio Management. vol.27, n.1(Fall 2000); pg. 82.

REILLY, F.K.; NORTON, E. A. Investments. 7 ed. Thomson, 2006.

RICHARDSON, R.J. Pesquisa social: métodos e técnicas. 3. ed. São Paulo: Atlas, 1999.

SANTOS, J.E. Volatilidade do mercado acionário brasileiro: negociação ou passagem do tempo? Um estudo empírico. Resenha da BM\&F, n. 148. Disponível em: http://scholar.google.com.br/scholar?hl=ptBR\&lr=\&q=cache:GwxNo4ekzVQJ:www3.bmf. com.br/pages/Educacional1/publicacoes/Resenha1/PDFs/Res148/Art04148.pdf+volatilidade + mercado+a\%C3\%A7\%C3\%B5es. Acesso em 04/08/2006.

SCHWERT, G.W. Stock Market Volatility. Financial Analysts Journal. vol. 46, n.3 (May/Jun 1990); pg. 23

SCHWERT, G.W. Why Does Stock Market Volatility Change Over Time? The Journal of Finance. Vol, 44, n. 5. (Dec., 1989), pp. 1115-1153.

SECURATO, J.R. Cálculo Financeiro das Tesourarias - Bancos e Empresas. São Paulo: Saint Paul, 2005.

SILVA, M. L. F. Plano Real e Âncora Cambial. Revista de Economia Política, V. 22. N 3 (87), Julho - setembro, 2002.

STOCK, J. H.; WATSON, M.K. Econometria. São Paulo: Addison Wesley, 2004. 
YOUNG. P.J.; JONHSON, R An examination relative volatility in the German. Debt an Equity Markets. Disponível em:

http://www.fma.org/Stockholm/Papers/RelativeVolatilityinGermanMarkets FMA.pdf (2005) . Acesso em: 20/06/06.

YOUNG. P.J.; JONHSON, R. Bond market volatility compared with stock market volatility: Evidence from the UK. Journal of Asset Management; Sep 2002; vol. 3, n. 2. pp 101.

YOUNG. P.J.; JONHSON, R. Bond Market Volatility vs. Stock Market Volatility: Evidence from Switzerland. Disponível em: http://www.fma.org/Zurich/Papers/570191.pdf. (2004). Acesso em: 20/06/06. 